\title{
An Autoantigen Atlas from Human Lung HFL1 Cells Offers Clues to Neurological and Diverse Autoimmune Manifestations of COVID-19
}

Julia Y. Wang ${ }^{1 *}$, Wei Zhang ${ }^{2}$, Michael W. Roehrl ${ }^{1}$, Victor B. Roehrl ${ }^{1}$, and Michael H. Roehrl ${ }^{3,4 *}$

\author{
${ }^{1}$ Curandis, New York, USA \\ ${ }^{2}$ Department of Gastroenterology, Affiliated Hospital of Guizhou Medical University, Guizhou, China \\ ${ }^{3}$ Department of Pathology and ${ }^{4}$ Human Oncology and Pathogenesis Program, Memorial Sloan Kettering \\ Cancer Center, New York, USA
}

*Correspondence: julia@curandis.com, roehrlm@mskcc.org

Short title: Autoantigen Atlas of COVID-19

Summary sentence: An autoantigenome by dermatan sulfate affinity from human lung HFL1 cells may explain neurological and autoimmune manifestations of COVID-19

Keywords: COVID-19, SARS-Cov-2, autoantigens, autoantibodies, dermatan sulfate, autoimmunity 


\begin{abstract}
COVID-19 is accompanied by a myriad of both transient and long-lasting autoimmune responses. Dermatan sulfate (DS), a glycosaminoglycan crucial for wound healing, has unique affinity for autoantigens (autoAgs) from apoptotic cells. DS-autoAg complexes are capable of stimulating autoreactive B cells and autoantibody production. Using DS affinity, we identified an autoantigenome of 408 proteins from human fetal lung fibroblast HFL11 cells, at least 231 of which are known autoAgs. Comparing with available COVID data, 352 proteins of the autoantigenome have thus far been found to be altered at protein or RNA levels in SARS-Cov-2 infection, 210 of which are known autoAgs. The COVID-altered proteins are significantly associated with RNA metabolism, translation, vesicles and vesicle transport, cell death, supramolecular fibrils, cytoskeleton, extracellular matrix, and interleukin signaling. They offer clues to neurological problems, fibrosis, smooth muscle dysfunction, and thrombosis. In particular, 150 altered proteins are related to the nervous system, including axon, myelin sheath, neuron projection, neuronal cell body, and olfactory bulb. An association with the melanosome is also identified. The findings from our study illustrate a strong connection between viral infection and autoimmunity. The vast number of COVID-altered proteins with propensity to become autoAgs offers an explanation for the diverse autoimmune complications in COVID patients. The variety of autoAgs related to mRNA metabolism, translation, and vesicles raises concerns about potential adverse effects of mRNA vaccines. The COVID autoantigen atlas we are establishing provides a detailed molecular map for further investigation of autoimmune sequelae of the pandemic.
\end{abstract}




\section{Introduction}

The emergence of the novel coronavirus SARS-CoV-2 has dragged the world into a prolonged pandemic. Aside from the intensively studied ACE2, heparan sulfate is another crucial entry receptor for coronaviruses (1). Dermatan sulfate (DS), structurally and functionally similar to heparan sulfate and heparin, belongs to the glycosaminoglycan family. Many viruses, including Ebola, Vaccinia, Zika, Dengue, and Hepatitis C viruses, have been shown to interact with glycosaminoglycans (2-5). These polyanionic polysaccharides consist of disaccharide repeating units of amino sugars and uronic acids with varying degrees of sulfation. Glycosaminoglycans are major components of the extracellular matrix and basement membrane, act as a filler between cells and tissue fibers and have numerous biological functions.

DS is most abundant in the skin but is also found in lungs, blood vessels, heart valves, and tendons. DS plays important roles in cell death, wound healing, and tissue repair. In human wound fluid, DS is the most abundant glycosaminoglycan (6). Its biosynthesis is increased by fibroblasts, epithelial cells, and capillary endothelial cells in wounded skin, mucosal ulcers, and inflammationassociated angiogenesis (7-9). Its molecular size also changes during wound healing, with elongated DS polymers packing along thin collagen fibrils in wounded skin (10). After tissue injury, fibroblasts require DS to migrate from the stroma surrounding the injury into the fibrin-laden wound to facilitate granulation tissue formation and wound healing (11).

DS is also a key molecule in autoimmunity, as we have discovered (12-16). DS is the most potent among glycosaminoglycans in stimulating autoreactive B1 cells and autoantibody production (12, 13). DS has a peculiar affinity to apoptotic cells and their released autoantigens (autoAgs), and macromolecular autoAg-DS affinity complexes are capable of engaging autoBCRs in a dual signaling event to activate B1 cells $(13,14)$. Recently, we also found that DS may steer autoreactive B1 cell fate at the pre-B stage by regulating the immunoglobulin heavy chain of the precursor BCR (17). Our studies illustrate a unifying property of autoAgs, i.e., self-molecules with DS affinity have a high propensity to become autoAgs, which explains how seemingly unrelated self-molecules can all induce humoral autoimmunity via similar immunological signaling events. In support of our hypothesis and by using DS affinity, we have cataloged hundreds of classic and novel autoAgs $(14-16,18)$.

A diverse spectrum of autoimmune symptoms has been observed in COVID-19 patients, including autoimmune cytopenia, multisystem inflammatory syndrome in children, immune-mediated 
neurological syndromes, Guillain-Barré syndrome, connective tissue disease-associated interstitial lung disease, antiphospholipid syndrome, autoimmune hemolytic anemia, autoimmune encephalitis, systemic lupus erythematosus, optic neuritis and myelitis, and acquired hemophilia (19-26). Many autoantibodies have been identified in COVID patients, including ANA (antinuclear antibody), ENA (extractable nuclear antigen), ANCA (anti-neutrophil cytoplasmic antibody), lupus anticoagulant, antiphospholipid, anti-IFN, anti-myelin oligodendrocyte glycoprotein, and antiheparin-PF4 complex (19-27).

To understand autoimmune sequelae of COVID, we aimed to establish a COVID autoantigen atlas that will serve as a molecular map to guide further investigation. In this study, we identified an autoantigenome of 408 proteins from human fetal lung fibroblast HFL1 cells by DS-affinity fractionation and protein sequencing, with at least 231 being known autoAgs. We then compared these with currently available data from SARS-CoV-2-infected patients and cells (as of 12/14/2020 in Coronascape) (28-48). Remarkably, 352 (86.3\%) of these proteins have been found to be altered (up- or down-regulated) at protein and/or RNA expression levels, and 210 of the COVID-altered proteins are known autoAgs in a great variety of autoimmune diseases and cancers. The COVID-altered proteins reveal intricate host responses to the viral infection and point to close associations with diverse disease manifestations of COVID-19.

\section{Results and Discussion}

\section{An autoantigenome of $\mathbf{4 0 8}$ proteins with DS-affinity from HFL1 cells}

Proteins extracted from HFL1 cells were fractionated with DS-affinity resins. The DS-binding fraction eluting with $0.5 \mathrm{M} \mathrm{NaCl}$ yielded 306 proteins by mass spectrometry sequencing, corresponding to proteins with medium-to-strong DS affinity. The fraction eluting with $1.0 \mathrm{M} \mathrm{NaCl}$ yielded 121 proteins, corresponding to proteins with very strong DS affinity. After excluding redundancies, a total of 408 unique proteins were obtained (Table 1). To verify how many of these proteins are known autoAgs, we conducted an extensive literature search for autoantibodies specific for each protein. Remarkably, at least 231 (56.6\%) of our DS-affinity proteins already have known associated specific autoantibodies in various diseases and are thus confirmed autoAgs (see references in Table 1).

Of those not yet confirmed as autoAgs, a majority are similar to known autoAgs. As an example, we identified 18 ribosomal proteins, of which 9 have been individually identified as autoAgs (Table 1); however, anti-ribosomal autoantibodies are reported to react with a heterogeneous pool of 
many ribosomal proteins (49). Therefore, many of the ribosomal proteins we identified may be true but yet-to-be-confirmed autoAgs. As another example, autoantibodies against the $20 \mathrm{~S}$ proteasome core are reported to be polyspecific and react with many subunits (50). Thus, although only 7 of 15 proteasome proteins we identified are thus far individually confirmed, the remainder may be true but yet-to-be-specified autoAgs. Similarly, some members of eukaryotic translation initiation and elongation factors are confirmed autoAgs, while others await confirmation. In summary, the putative autoantigenome from HFL1 cells provides at least 231 confirmed and 177 yet-to-confirm putative autoAgs (Table 1).

\section{DS-affinity proteins are functionally connected and enriched}

To find out whether DS-affinity-associated proteins are a random collection or biologically connected, we performed protein-protein interaction analyses with STRING (51). Of the 408 DSassociated proteins, 405 proteins recognized by STRING (ANP32C, ANXA2P2, HSP90AA2 excluded) have 7,582 interactions, whereas a random set of 405 proteins is expected to have only 3,060 interactions; hence, DS-affinity proteins represent a significantly connected network with PPI enrichment p-value <1.0E-6 (Fig. 1). Based on cellular component classification, these proteins are highly concentrated in the nucleus (226 proteins), vesicles (111 proteins), ribonucleoprotein complexes (95 proteins), and the cytoskeleton (95 proteins).

Pathway and process analyses by STRING and Metascape (28) revealed that the mRNA metabolic process is the most enriched GO Biological Process, and the top KEGG pathways are the spliceosome and protein processing in the endoplasmic reticulum. The top Reactome pathways are metabolism of RNA, metabolism of proteins, and axon guidance. The top local network clusters are GTP hydrolysis and joining of the 605 ribosomal subunits and mRNA splicing. The Molecular Complex Detection algorithm identified clusters related to eukaryotic translation elongation, cellular responses to stress, regulation of RNA stability, COPI-independent Golgi-to-ER retrograde traffic, and supramolecular fiber organization.

\section{2 known and putative autoAgs are COVID-altered proteins}

To find out which autoAgs may be involved in COVID-19, we compared the DS-affinity autoantigenome with proteins and genes that are up- or down-regulated in SARS-CoV-2 infection (Coronascape database comparison, Supplemental Table 1) (28-48). Remarkably, 352 (86.3\%) of the 408 DS-affinity proteins have been found to be altered (up- and/or down-regulated at protein and/or mRNA levels) in COVID-19 patients or SARS-CoV-2 infected cells (Table 1). Of these, 260 
are reported as up-regulated and 303 as down-regulated (including 211 that are both up- and down-regulated). The numbers are not conflicting, because the COVID data were generated by multiple proteomic and transcriptomic methods and different cells and tissues. A protein may not be overexpressed even when its mRNA is up-regulated, and a protein/gene may be up-regulated in one tissue or patient but down-regulated in another tissue or patient. A protein is considered altered if it is up- or down-regulated at the protein or RNA level and, in relation to SARS-CoV-2 infection, it is considered a COVID-altered protein.

Protein-interaction analysis revealed that 352 COVID-altered proteins form a highly connected network, exhibiting 6,286 interactions (vs. 2,451 expected; PPI enrichment p-value <1.0E-6) (Fig. 2). Based on cellular component analysis, the altered proteins can be located to intracellular organelles (323 proteins), nucleus (199 proteins), endomembrane system (143 proteins), vesicles (99 proteins), ribonucleoprotein complex (87 proteins), cytoskeleton (84 proteins), ER (72 proteins), and cell projections (52 proteins). Organelles with significant numbers of component proteins identified include the melanosome (30/105 proteins in melanosome), proteasome (16/64), polysome (13/66), spliceosome (34/187), ficolin-1-rich granule lumen (22/125), azurophil granules (17/155), and myelin sheath (26/157).

Similarly, the group of 260 up-regulated proteins is highly connected (3,747 interactions vs. 1,424 expected) with significant enrichment in proteins associated with RNA and mRNA metabolism, translation, vesicles and vesicle-mediated transport, and regulation of cell death (Fig. 3A). The group of 303 down-regulated proteins is also highly connected (4,860 interactions vs. 1,907 expected), and these proteins are significantly related to RNA metabolism, translation, vesicles, cytoskeleton, and extracellular matrix (Fig. 3B).

\section{Pathways and processes affected by COVID-altered proteins}

Network enrichment analysis by Metascape revealed that the 352 COVID-altered proteins are most significantly enriched in RNA metabolism, axon guidance, and translation (Table 2). Many processes, e.g., regulated exocytosis, wound healing, supramolecular fiber organization, smooth muscle contraction, and platelet degranulation are significantly affected by COVID-altered proteins regardless of whether they are up- or down-regulated. The up-regulated proteins are more related to axon guidance and interleukin signaling, whereas down-regulated proteins are more related to cellular response to stress and apoptosis. 
bioRxiv preprint doi: https://doi.org/10.1101/2021.01.24.427965; this version posted January 24, 2021. The copyright holder for this preprint (which was not certified by peer review) is the author/funder, who has granted bioRxiv a license to display the preprint in perpetuity. It is made available under aCC-BY 4.0 International license.

Table 2. Top enriched pathways and processes related to COVID-altered proteins

\begin{tabular}{|c|c|c|c|c|c|}
\hline COVID & Ontology & Description & Count & $\%$ & $\log _{10}(P)$ \\
\hline \multirow[t]{20}{*}{ Altered } & R-HSA-8953854 & Metabolism of RNA & 78 & 22.16 & -51.2 \\
\hline & R-HSA-422475 & Axon guidance & 63 & 17.90 & -40.6 \\
\hline & GO:0006412 & Translation & 66 & 18.75 & -35.9 \\
\hline & GO:0000377 & RNA splicing & 44 & 12.50 & -28.0 \\
\hline & GO:0045055 & Regulated exocytosis & 58 & 16.48 & -26.7 \\
\hline & GO:0006457 & Protein folding & 33 & 9.38 & -24.3 \\
\hline & R-HSA-1474244 & Extracellular matrix organization & 33 & 9.38 & -20.6 \\
\hline & GO:0043687 & Post-translational protein modification & 35 & 9.94 & -20.0 \\
\hline & GO:0071826 & Ribonucleoprotein complex subunit organization & 32 & 9.09 & -19.7 \\
\hline & CORUM:5615 & Emerin complex 52 & 13 & 3.69 & -18.8 \\
\hline & GO:0010638 & Positive regulation of organelle organization & 40 & 11.36 & -16.1 \\
\hline & GO:0042060 & Wound healing & 38 & 10.80 & -15.6 \\
\hline & GO:0006913 & Nucleocytoplasmic transport & 30 & 8.52 & -15.6 \\
\hline & R-HSA-114608 & Platelet degranulation & 19 & 6.27 & -15.6 \\
\hline & R-HSA-5653656 & Vesicle-mediated transport & 40 & 11.36 & -15.4 \\
\hline & GO:0097435 & Supramolecular fiber organization & 41 & 11.65 & -15.1 \\
\hline & CORUM:1335 & SNW1 complex & 10 & 3.30 & -15.1 \\
\hline & GO:0002181 & Cytoplasmic translation & 18 & 5.11 & -15.1 \\
\hline & R-HSA-445355 & Smooth Muscle Contraction & 13 & 3.69 & -14.9 \\
\hline & GO:0031647 & Regulation of protein stability & 27 & 7.67 & -14.9 \\
\hline \multirow[t]{3}{*}{ Up } & R-HSA-72163 & mRNA Splicing - Major Pathway & 23 & 8.85 & -18.8 \\
\hline & R-HSA-449147 & Signaling by Interleukins & 26 & 10.00 & -12.6 \\
\hline & GO:0000904 & Cell morphogenesis involved in differentiation & 31 & 11.92 & -11.3 \\
\hline \multirow[t]{3}{*}{ Down } & R-HSA-2262752 & Cellular responses to stress & 55 & 18.15 & -34.5 \\
\hline & R-HSA-109581 & Apoptosis & 23 & 7.59 & -17.5 \\
\hline & GO:0035966 & Response to topologically incorrect protein & 22 & 7.26 & -15.0 \\
\hline
\end{tabular}

Count: the number of DS-affinity proteins with membership in the given ontology term. \%: percentage of DS-affinity proteins in the given ontology term.

\section{COVID-altered autoAgs are strongly related to the nervous system}

COVID-19 patients frequently report neurological problems, such as loss of smell and taste, dizziness, headache, and stroke. While most symptoms are transient, some recovered patients are haunted by lingering neurological and psychological problems long after the viral infection. The underlying cause of transient and long-lasting neurological effects of COVID-19 has been puzzling. Analysis of COVID-altered proteins revealed a strong link to the nervous system. Of the 352 COVID-altered proteins, at least 150 are related to the nervous system (Fig. 4A). More than 60 proteins are related to axon guidance based on ontology analyses (Table 2 and Fig. 4A). In addition, there are 39 proteins related to neuron projection, 26 proteins related to myelin sheath, 25 proteins related to axon growth cone (52), 16 proteins related to neuronal cell body, 4 proteins related to cerebellar Purkinje cell layer, 3 proteins related to peripheral nervous system axon regeneration, and 2 proteins related to radial glial scaffolds. In particular, we found that 23 COVIDaltered proteins are related to the olfactory bulb (53), which may explain the loss of smell in many COVID-19 patients. 
Most of these proteins are known autoAgs, e.g., ACTB, CANX, A2M, APOA1, CAPZA1, DPYSL2, FLNA, GDI2, LGALS1, MSN, PDIA3, PFN2, TNC, UCHL1, VCP, and VCL (see autoAg references in Table 1). Some yet-to-be-confirmed autoAgs with direct relation to the nerve system, e.g., NES (expressed mostly in nerve cells) and APOD (expressed by oligodendrocytes), warrant further investigation.

The COVID-altered proteins are also associated with a number of neurological diseases (Fig. 4B). By comparing our data with published proteomes, 23 proteins were similarly found in neuronal infection by Japanese encephalitis virus (54), 21 proteins in neuroblastoma (55), 22 proteins in glioblastoma (56), 26 proteins in neurodegeneration in Down syndrome (57), 22 proteins in Alzheimer disease hippocampus (58), 24 proteins in schizophrenia (59), 17 proteins in cerebral ischemia (60), and 17 proteins in Parkinson disease (61).

Coronavirus-induced demyelination has been reported in a mouse model of multiple sclerosis (62), which may explain our identification of 26 altered proteins related to the myelin sheath in SARS-CoV-2 infection. In a mouse brain injury model, DS appears to play an important role in glial scar formation and regeneration of dopaminergic axons (63). Alterations of white matter DS and extracellular matrix are specific, dynamic, and widespread in multiple sclerosis patients (64). DS has recently been reported to promote neuronal differentiation in mouse and human neuronal stem cells (65). Given the various functional roles of DS, our identification of a large number of known and putative autoAgs with DS affinity related to the nervous system is a compelling finding.

\section{COVID-altered autoAgs are related to cell death, wound healing, and blood coagulation}

SARS-CoV-2 infection causes host cell death and leads to tissue injury. Wound healing, cellular response to stress, and apoptosis are among the most significant processes related to COVIDaltered proteins (Table 2 and Fig. 5A). For example, we identified 66 proteins related to regulation of cell death and 23 related to regulation of apoptotic signaling pathways. DS binds to apoptotic cells and autoAgs released from dying cells, which has led to our previous identification of hundreds of autoAgs $(13-16,18)$. Upon tissue injury, DS biosynthesis is ramped up by fibroblasts and epithelial and endothelial cells (7-9). After tissue injury, DS assists fibroblast migration into the wound to facilitate granulation tissue formation and wound healing (11). DS, similar to heparin, is also an important anticoagulant that inhibits clot formation via interaction with antithrombin and heparin cofactor II (66). Given these biological roles of DS, it is consistent that a large number of COVID-altered proteins related to cell death and tissue injury are identified by DS-affinity. 
Blood coagulation and thrombosis are frequent complications of COVID-19. Platelet degranulation is found to be significantly associated with at least 18 altered proteins (Table 2 and Fig. 5A). COVID-altered proteins are related to blood coagulation, platelet activation, platelet alpha granules, fibrinogen binding, fibrinogen complex, platelet plug formation, von Willebrand factor A-like domain superfamily, and platelet-derived growth factor binding. Collagens, which support platelet adhesion and activation, and collagen biosynthesis and modifying enzymes are also among the COVID-altered proteins, e.g., collagen type VI trimer and type I trimer (Fig. 5A). The majority of these altered proteins are known autoAgs, e.g., ALB, ANXA5, C1QBP, CALM1, CAPZB, COL1A1, COL1A2, COL6A1, FBLN1, FN1, PLEC, PPIB, THBS1, TLN1, TUBA4A, and YWHAZ (see autoAg references in Table 1). Some are unknown and await further investigation, e.g., AP3B1, CRK, CTSB, EHD2, PLOD1, PSAP, and PARKAR2A.

\section{Supramolecular fibril alteration offers clues to muscle dysfunction and fibrosis}

Over 50 supramolecular filament proteins are identified by DS-affinity from HFL1 cells. Remarkably, nearly all (except for one) are found to be altered in SARS-CoV-2 infection, and the majority have already been reported as autoAgs (Table 1). They include various isoforms of actin, actinin, collagen, filamin, fibronectin, fibulin, dynactin, dynein, lamin, myosin, nestin, nexilin, profilin, plectin, plastin, proteoglycan, septin, spectrin, talin, tropomyosin, tubulin, vinculin, and vimentin (Table 1, Fig. 5B). These proteins are major components of the extracellular matrix, basement membrane, cell cytoskeleton, cytoskeletal motors, muscle filaments, and contractile motors of muscle cells.

A significant number of COVID-altered proteins are related. Emerin complex and smooth muscle contraction are among the top enriched biological processes of COVID-altered proteins (Table 2, Fig. 5B). Emerin is highly expressed in cardiac and skeletal muscle, and emerin mutations cause $X$-linked recessive Emery-Dreifuss muscular dystrophy, cardiac conduction abnormalities, and dilated cardiomyopathy. Smooth muscle resides primarily in the walls of hollow organs where it performs involuntary movements, e.g., respiratory tract, blood vessels, gastrointestinal tract, and renal glomeruli. In addition, we identified proteins with significant association to myofibrils (the contractile elements of skeletal and cardiac muscle; 23 proteins) (Fig. 5B), stress fiber (a contractile actin filament bundle that consists of short actin filaments with alternating polarity: MYH9, MYLK, FLNB, TPM1, TPM2, TPM3, TPM4, ACTN1, ACTN4), muscle filament sliding (the sliding of actin thick filaments and myosin thick filaments past each other in muscle contraction), 
Z disk (plate-like region of a muscle sarcomere to which the plus ends of actin filaments are attached), intercalated disc (a cell-cell junction complex at which myofibrils terminate in cardiomyocytes, mediates mechanical and electrochemical integration between individual cardiomyocytes), and negative regulation of smooth muscle cell-matrix adhesion (2 proteins; SERPINE1, APOD).

Pulmonary fibrosis is prominent in COVID-19 and contributes to lethality in some cases $(67,68)$. Fibrosis, or fibrotic scarring, is pathological wound healing in which excessive extracellular matrix components are produced by fibroblasts and accumulate in the wounded area. Histopathological examination of COVID-19 patients found highly heterogenous injury patterns reminiscent of exacerbation of interstitial lung disease, including interstitial thickening, fibroblast activation, and deposition of collagen fibrils (22). We identified a significant number of COVID-altered proteins that are associated with collagen bundles and collagen biosynthesis and modifying enzymes (16 proteins), extracellular matrix organization (33 proteins), supramolecular fibers, and amyloid formation offering functional links to fibrosis (Fig. 5B).

\section{Potential autoAgs in COVID-19 patients and a connection to the melanosome}

To find out how altered proteins may differ in patients, we compared our putative autoantigenome to published single-cell RNA sequencing data of 6 patients hospitalized for COVID-19 $(28,34)$ and identified 32-59 putative autoAgs per patient (Fig. 6). Interestingly, while identified from different patients, the altered proteins/genes identified share involvement of leukocyte activation, vesicles and vesicle transport, protein processing in the ER (including antigen processing and presentation), regulation of cell death, translation, muscle contraction, myelin sheath, and curiously, the melanosome (Fig. 6). The estrogen signaling pathway and thyroid hormone synthesis are found to be associated with altered proteins in some patients. Patient C2 has 5 altered proteins related to neuron differentiation regulation, and patient $\mathrm{C} 4$ has 6 altered proteins related to neuron death.

Eleven altered proteins were identified in all 6 patients, including known autoAgs (ACTB, EEF1A1, EEF2, ENO1, LGALS1, PABPC1) and unknown ones (CRTAP, NAP1L1, PSAP, RRBP1, TPT1) (Table 1). AHNAK (neuroblast differentiation-associated protein, a known autoAg in lupus) was identified in 5 patients. Overall, a majority of the altered proteins identified from the 6 COVID patients are known autoAgs, e.g., CALM1, CALR, CALU, CANX, DNAJB11, HDGF, HSPA5 (BiP), IQGAP1, LCP1, LMNB1, MYH9, NACA, P4HB, SFPQ, PDIA3, TPM3, TUBB, VCP, VIM, WARS, 
and YB3 (Table 1). Unknown or putative autoAgs include CAP1, CTSB, HDLBP, HYOU1, SND1, and SUB1.

We initially identified 30 DS-affinity proteins from HFL1 cells related to the melanosome, and, intriguingly, all of these are also COVID-altered proteins (Fig. 5B). Based on STRING GO analysis, the melanosome is the most significant cellular component related to altered proteins in all 6 patients (with false discovery rates ranging from 1.52E-8 to 1.11E-23). In HIV infection, melanosome production is stimulated in some patients and leads to an increase in pigmented lesions (69). However, melanosome involvement in COVID-19 is not known. Two Wuhan doctors in intensive care for COVID temporally turned dark, although the cause was thought to be a drug reaction. A COVID patient has been reported with acute flaccid tetraparesis and maculopapular pigmented plaques on the limbs (70). In mice, coronavirus induces an acute and long-lasting retinal disease, with initial retinal vasculitis followed by retinal degeneration that is associated with retinal autoantibodies and retinal pigment epithelium autoantibodies (71).

\section{Association between autoimmunity and virus infections}

We identified COVID-altered proteins with DS-affinity that are involved in the host response to various aspects of viral infection and that possess a high propensity to become autoAgs. For example, viral RNA metabolism, translation, vesicles, and vesicle transport contribute a large number of known and putative autoAgs. In addition, viral processes, particularly symbiont processes and interspecies interactions between host and viruses, contribute significantly to altered proteins (Fig. 7A). For example, among altered proteins related to response to viral processes, HSPA8, DDB1, RAD23A, PABPC1, PPIB, P4HB, LGALS1, GSN, and ILF3 are known autoAgs (Table 1).

In particular, COVID-altered cytoskeletal filament proteins shed light on viral trafficking in host cells. SARS-CoV-2 infection induces profound remodeling of the cytoskeleton, and replicating viral vesicles are surrounded by a network of intermediate filaments (72). The cytoskeletal network appears to facilitate coronavirus transport and expulsion, with thickening actin filaments providing the bending force to extrude viral vesicles (73). We identified 84 altered proteins related to the cytoskeleton and 84 altered proteins related to vesicle-mediated transport (Fig. 2). These altered proteins are implicated in various processes, including cytoskeleton-dependent intracellular transport, actin fiber-based movement, actin-mediated cell contraction, microtubuledependent trafficking from the Golgi to the plasma membrane, and transport along microtubules. 
Many positive-strand RNA viruses (including SARS-CoV-2, Enterovirus, Hepatitis C virus, Norovirus, and Poliovirus) hijack a common group of nuclear factors to support the biosynthetic functions required for viral replication and propagation (74). 20 of these hijacked nuclear proteins are identified by DS-affinity in our study (Fig. 7). In addition, altered proteins are found in other viral infections, including porcine reproductive and respiratory syndrome virus (75), H5N1 avian influenza viruses $(76,77)$, Japanese encephalitis virus $(54)$, Rift Valley fever virus $(78)$, Hepatitis B virus (79), HIV (80-82), Herpes Simplex virus (83), and Epstein-Barr virus infection (Fig. 7B and STRING ontology analysis).

\section{Autoimmunity concerns for mRNA vaccines}

Our study identified a large number of known and putative autoAgs that are related to mRNA metabolism, translation, vesicles, and vesicle trafficking (Figs. 1-2). This finding begs us to wonder whether mRNA vaccines may induce unintended autoimmune consequences in the long term. mRNA vaccines are essentially synthetic viral vesicles. To induce protective immunity, mRNA vaccine vesicles will need to be transported into cells where they hijack the host cell machinery to produce a viral protein antigen, whereupon the antigen will be processed and presented by $\mathrm{MHC}$ molecules to induce $\mathrm{B}$ and $\mathrm{T}$ cell responses.

mRNA translation requires ribosomes, translation initiation factors, aminoacyl-tRNA synthetases, and elongation factors. We identified 18 ribosomal proteins by DS-affinity, all of which are altered in SARS-CoV-2 infection and 9 of which are known autoAgs (see references in Table 1). We also identified 15 eukaryotic translation initiation factor proteins, with 12 of them being COVID-altered and 4 being known autoAgs (Table 1 ). Six elongation factor proteins ( 5 subunits of EEF1 complex, EEF2) were identified by DS-affinity, of which all 6 are COVID-altered and 3 are known autoAgs (Table 1). Six tRNA synthetases were identified, with 5 being known autoAgs and 3 (AARS, EPRS, WARS) COVID-altered (Table 1). Autoantibodies to AARS are associated with interstitial lung disease and myositis $(84,85)$. EPRS appears to regulate pro-fibrotic protein synthesis during cardiac fibrosis (86). Gene mutations of WARS cause an autosomal dominant neurologic disorder characterized by slowly progressive distal muscle weakness and atrophy affecting both the lower and upper limbs $(87,88)$.

Once synthesized, the exogenous protein antigens are degraded by proteasomes, and the resulting peptides are transported into the ER where they are loaded onto MHC molecules by 
peptide loading complexes for presentation to T cells. In relation to these steps, 15 proteasome subunits were identified by DS-affinity, with 12 being COVID-altered and 7 being known autoAgs (Table 1). Nine proteins related to antigen processing and presentation are found to be altered in the 6 COVID-19 patients analyzed in this study, including HSPA1A, HSPA8, HSP90AA1, HSPAB1, HSPA5, PDIA3, CANX, CALR, and CTSB, with 7 being known autoAgs (Fig. 5 and Table 1).

In addition, among the 352 COVID-altered proteins identified in this study, 69 proteins are associated with mRNA metabolism (Fig. 2). Many of these proteins may be irrelevant to nonreplicating mRNA molecules in mRNA vaccines, however, some are likely needed in processes such as 3' end processing, deadenylation, and nonsense-mediated decay. For example, we identified poly(A) tail binding proteins PABPC1 and PABPC4 as COVID-altered proteins, both of which have been reported as autoAgs (Table 1).

mRNA vaccines are synthetic vesicles. This study identified 99 altered proteins associated with vesicles and 84 proteins associated with vesicle-mediated transport (Figs. 1, 2, 5). Although it is not clear which host molecules are involved in extra- and intracellular transport and uptake of mRNA vaccine vesicles, some of the vesicle-related proteins identified as DS-affinity proteins may be involved, e.g., proteins of receptor-mediated endocytosis (APOA1, CALR, CANX, CAP1, CLTC, HSP90AA1, HSP90B1, HSPG2, ITGB1, YWHAH) or phagocytosis (ACTB, CRK, GSN, HSP90AA1, HSP90AB1, MYH9, MYO1C, PDIA6, RAB7A, THBS1, TXNDC5).

Overall, a significant number of autoAgs related to different steps of mRNA vaccine action were identified in this study; however, our findings do not mean that these autoAgs will lead to aberrant autoimmune reactions as a result of mRNA vaccination. The development of autoimmune diseases or autoimmunity-related diseases entails a complex cascade of molecular and cellular interactions. Long-term monitoring of autoimmune adverse effects will be needed.

\section{Conclusion}

This study identifies an autoantigenome of 408 proteins from human fetal lung fibroblast HFL1 cells by DS-affinity and protein sequencing, of which at least 231 proteins are confirmed autoAgs. Of these, $352(86.3 \%)$ are found to be altered in SARS-CoV-2 infection when compared to published data, with at least 210 COVID-altered proteins being known autoAgs. The altered proteins are significantly enriched in a number of pathways and processes and are closely 
connected to various disease manifestations of COVID-19, particularly neurological problems, fibrosis, muscle dysfunction, and thrombosis.

Viral infections cause significant perturbations of normal cellular and tissue component molecules in the host, leading to cell death and tissue injury. Autoantigens resulting from molecular alterations may result directly from the injury or indirectly from responses to the injury. As a stress response, DS biosynthesis may be ramped up to facilitate wound healing and dead cell clearance. DS associates with autoAgs and stimulates autoreactive B cells and autoantibody production. Specific autoantibodies that are initially induced in response to a certain injury site may circulate and attack secondary sites where the autoAgs are also expressed, leading to a complex array of local and systemic autoimmune diseases.

This study illustrates a strong connection between viral infection and autoimmunity. The COVID19 autoantigenome provides a detailed molecular map for investigating the diverse spectrum of autoimmune sequelae caused by the pandemic. The autoantigen atlas we are establishing may also serve as a detailed molecular reference for monitoring possible autoimmune reactions to mRNA vaccines and other viral infections.

\section{Materials and Methods}

\section{HFL1 cell culture}

The HFL1 cell line was obtained from the ATCC (Manassas, VA, USA) and cultured in Eagle's Minimum Essential Medium supplemented with 10\% fetal bovine serum (Thermo Fisher) and a penicillin-streptomycin-glutamine mixture (Thermo Fisher) at $37^{\circ} \mathrm{C}$.

\section{Protein extraction}

About 100 million cells were harvested and suspended in $10 \mathrm{ml}$ of $50 \mathrm{mM}$ phosphate buffer $(\mathrm{pH}$ 7.4) containing the Roche Complete Mini protease inhibitor cocktail. Cells were homogenized on ice with a microprobe sonicator until the turbid mixture became nearly clear with no visible cells left. The homogenate was centrifuged at $10,000 \mathrm{~g}$ at $4{ }^{\circ} \mathrm{C}$ for $20 \mathrm{~min}$, and the supernatant was collected as the total protein extract. Protein concentration was measured with the RC DC protein assay (Bio-Rad). 


\section{DS-Sepharose resin preparation}

$20 \mathrm{ml}$ of EAH Sepharose 4B resins (GE Healthcare Life Sciences) were washed with distilled water three times and mixed with $100 \mathrm{mg}$ of DS (Sigma-Aldrich) in $10 \mathrm{ml}$ of $0.1 \mathrm{M} \mathrm{MES} \mathrm{buffer,} \mathrm{pH}$ 5.0. $500 \mathrm{mg}$ of $\mathrm{N}$-(3-dimethylaminopropyl)-N'-ethylcarbodiimide hydrochloride (Sigma-Aldrich) powder was added to the mixture. The reaction proceeded by end-over-end rotation at $25{ }^{\circ} \mathrm{C}$ for $16 \mathrm{~h}$. After coupling, resins were washed with water and equilibrated first with a low-pH buffer (0.1 $\mathrm{M}$ acetate, $0.5 \mathrm{M} \mathrm{NaCl}, \mathrm{pH} 5.0$ ) and then with a high-pH buffer (0.1 M Tris, $0.5 \mathrm{M} \mathrm{NaCl}, \mathrm{pH} 8.0)$.

\section{DS-affinity fractionation}

The total proteins extracted from HFL1 cells were fractionated on DS-Sepharose columns with a BioLogic Duo-Flow system (Bio-Rad). About $40 \mathrm{mg}$ of proteins in $40 \mathrm{ml}$ of $10 \mathrm{mM}$ phosphate buffer ( $\mathrm{pH}$ 7.4; buffer $\mathrm{A}$ ) were loaded onto the column at a rate of $1 \mathrm{ml} / \mathrm{min}$. Unbound proteins were washed off with $60 \mathrm{ml}$ of buffer $A$, and weakly bound proteins were eluted with $40 \mathrm{ml}$ of 0.2 $\mathrm{M} \mathrm{NaCl}$ in buffer A. DS-binding proteins were eluted with sequential 40-ml step gradients of 0.5 $\mathrm{M}$ and $1.0 \mathrm{M} \mathrm{NaCl}$ in buffer $\mathrm{A}$. Fractions were desalted and concentrated to $0.5 \mathrm{ml}$ with 5-kDa cutoff Vivaspin centrifugal filters (Sartorius). Fractionated proteins were separated by 1-D SDSPAGE in $4-12 \%$ Bis-Tris gels, and the gel lanes corresponding to $1.0 \mathrm{M}$ or $0.5 \mathrm{M} \mathrm{NaCl}$ elutions were divided into two or three sections for sequencing.

\section{Mass spectrometry sequencing}

Protein sequencing was performed at the Taplin Biological Mass Spectrometry Facility at Harvard Medical School. Proteins in gels were digested with sequencing-grade trypsin (Promega) at $4{ }^{\circ} \mathrm{C}$ for 45 min. Tryptic peptides were separated on a nano-scale $\mathrm{C}_{18}$ HPLC capillary column and analyzed in an LTQ linear ion-trap mass spectrometer (Thermo Fisher). Peptide sequences and protein identities were assigned by matching the measured fragmentation pattern with proteins or translated nucleotide databases using Sequest. All data were manually inspected. Only proteins with $\geq 2$ peptide matches were considered positively identified.

\section{COVID data comparison with Coronascape}

DS-affinity proteins were compared with currently available proteomic and transcriptomic data from SARS-CoV-2 infection compiled in the Coronascape database (as of 12/14/2020) (28-48). These data had been obtained with proteomics, phosphoproteomics, interactome, ubiquitome, and RNA-seq techniques. Up- and down-regulated proteins or genes were identified by comparing COVID-19 patients vs. healthy controls and cells infected vs. uninfected by SARS- 
CoV-2. Similarity searches were conducted between our data and the Coronascape database to identify DS-affinity proteins (or their corresponding genes) that are up- and/or down-regulated in the viral infection.

\section{Pathway and process enrichment analysis}

Pathways and processes enriched in the putative autoantigenome were analyzed with Metascape (28). The analysis was performed with various ontology sources, including KEGG Pathway, GO Biological Process, Reactome Gene Sets, Canonical Pathways, CORUM, TRRUST, and DiGenBase. All genes in the genome were used as the enrichment background. Terms with a pvalue $<0.01$, a minimum count of 3 , and an enrichment factor (ratio between the observed counts and the counts expected by chance) $>1.5$ were collected and grouped into clusters based on their membership similarities. The most statistically significant term within a cluster was chosen to represent the cluster. Pathway hierarchical clustering was obtained with ShinyGo (89).

\section{Protein-protein interaction network analysis}

Protein-protein interactions among collections of DS-affinity proteins were analyzed by STRING (51), including both direct physical interaction and indirect functional associations. Interactions are derived from genomic context predictions, high-throughput lab experiments, co-expression, automated text mining, and previous knowledge in databases. Each interaction is annotated with a confidence score from 0 to 1 , with 1 being the highest, indicating the likelihood of an interaction to be true. Only interactions with high confidence (a minimum score of 0.7 ) are shown in the figures.

\section{Literature text mining}

Literature searches in Pubmed were performed for every DS-affinity protein identified in this study. Search keywords included the protein name, its gene symbol, alternative names and symbols, and the MeSH keyword "autoantibodies". Only proteins with their specific autoantibodies reported in PubMed-listed journal articles were considered "confirmed" autoAgs in this study. 


\section{Acknowledgements and funding statement}

This work was partially supported by Curandis, the US NIH, and a Cycle for Survival Innovation Grant (to MHR). MHR acknowledges the NIH/NCI R21 CA251992 and MSKCC Cancer Center Support Grant P30 CA008748. The funding bodies were not involved in the design of the study and the collection, analysis, and interpretation of data. We thank Jung-hyun Rho for technical assistance with experiments. We thank Ross Tomaino and the Taplin Biological Mass Spectrometry facility of Harvard Medical School for expert service with protein sequencing.

\section{Competing interest statement}

JYW is the founder and Chief Scientific Officer of Curandis. WZ was supported by the NIH and declares no competing interests. MWR and VBR are volunteers of Curandis. MHR is a member of the Scientific Advisory Boards of Trans-Hit, Proscia, and Universal DX but these companies have no relation to the study.

\section{Authors' contributions}

JYW directed the study, analyzed data, and wrote the manuscript. WZ performed some experiments and reviewed the manuscript. MWR and BVR assisted in data analysis and manuscript preparation. MHR consulted on the study and edited the manuscript. All authors have approved the manuscript. 


\section{References}

1. T. M. Clausen, D. R. Sandoval, C. B. Spliid, J. Pihl, H. R. Perrett, C. D. Painter, A. Narayanan, S. A. Majowicz, E. M. Kwong, R. N. McVicar, B. E. Thacker, C. A. Glass, Z. Yang, J. L. Torres, G. J. Golden, P. L. Bartels, R. N. Porell, A. F. Garretson, L. Laubach, J. Feldman, X. Yin, Y. Pu, B. M. Hauser, T. M. Caradonna, B. P. Kellman, C. Martino, P. Gordts, S. K. Chanda, A. G. Schmidt, K. Godula, S. L. Leibel, J. Jose, K. D. Corbett, A. B. Ward, A. F. Carlin, J. D. Esko, SARS-CoV-2 Infection Depends on Cellular Heparan Sulfate and ACE2. Cell 183, 1043-1057.e1015 (2020).

2. M. Tamhankar, D. M. Gerhardt, R. S. Bennett, N. Murphy, P. B. Jahrling, J. L. Patterson, Heparan sulfate is an important mediator of Ebola virus infection in polarized epithelial cells. Virology journal 15, 135 (2018).

3. R. D. Luteijn, F. van Diemen, V. A. Blomen, I. G. J. Boer, S. Manikam Sadasivam, T. H. van Kuppevelt, I. Drexler, T. R. Brummelkamp, R. J. Lebbink, E. J. Wiertz, A Genome-Wide Haploid Genetic Screen Identifies Heparan Sulfate-Associated Genes and the Macropinocytosis Modulator TMED10 as Factors Supporting Vaccinia Virus Infection. Journal of virology 93, (2019).

4. H. Gao, Y. Lin, J. He, S. Zhou, M. Liang, C. Huang, X. Li, C. Liu, P. Zhang, Role of heparan sulfate in the Zika virus entry, replication, and cell death. Virology 529, 91-100 (2019).

5. Y. Xu, P. Martinez, K. Séron, G. Luo, F. Allain, J. Dubuisson, S. Belouzard, Characterization of hepatitis C virus interaction with heparan sulfate proteoglycans. Journal of virology 89, 3846-3858 (2015).

6. S. F. Penc, B. Pomahac, T. Winkler, R. A. Dorschner, E. Eriksson, M. Herndon, R. L. Gallo, Dermatan sulfate released after injury is a potent promoter of fibroblast growth factor-2 function. $J$ Biol Chem 273, 28116-28121 (1998).

7. T. Pohle, M. Altenburger, M. Shahin, J. W. Konturek, H. Kresse, W. Domschke, Expression of decorin and biglycan in rat gastric tissue: effects of ulceration and basic fibroblast growth factor. Scandinavian journal of gastroenterology 36, 683-689 (2001).

8. L. Nelimarkka, H. Salminen, T. Kuopio, S. Nikkari, T. Ekfors, J. Laine, L. Pelliniemi, H. Järveläinen, Decorin is produced by capillary endothelial cells in inflammation-associated angiogenesis. Am J Pathol 158, 345-353 (2001).

9. P. H. Lee, J. M. Trowbridge, K. R. Taylor, V. B. Morhenn, R. L. Gallo, Dermatan sulfate proteoglycan and glycosaminoglycan synthesis is induced in fibroblasts by transfer to a three-dimensional extracellular environment. J Biol Chem 279, 48640-48646 (2004).

10. K. Kuwaba, M. Kobayashi, Y. Nomura, S. Irie, Y. Koyama, Size control of decorin dermatan sulfate during remodeling of collagen fibrils in healing skin. Journal of dermatological science 29, 185-194 (2002).

11. R. A. Clark, F. Lin, D. Greiling, J. An, J. R. Couchman, Fibroblast invasive migration into fibronectin/fibrin gels requires a previously uncharacterized dermatan sulfate-CD44 proteoglycan. J Invest Dermatol 122, 266-277 (2004).

12. J. Y. Wang, M. H. Roehrl, Glycosaminoglycans are a potential cause of rheumatoid arthritis. Proc Natl Acad Sci U S A 99, 14362-14367 (2002).

13. J. Y. Wang, J. Lee, M. Yan, J. H. Rho, M. H. Roehrl, Dermatan sulfate interacts with dead cells and regulates $\mathrm{CD5}(+)$ B-cell fate: implications for a key role in autoimmunity. Am J Pathol 178, 21682176 (2011).

14. J. H. Rho, W. Zhang, M. Murali, M. H. Roehrl, J. Y. Wang, Human proteins with affinity for dermatan sulfate have the propensity to become autoantigens. Am J Pathol 178, 2177-2190 (2011).

15. W. Zhang, J. H. Rho, M. H. Roehrl, J. Y. Wang, A comprehensive autoantigen-ome of autoimmune liver diseases identified from dermatan sulfate affinity enrichment of liver tissue proteins. $B M C$ Immunol 20, 21 (2019). 
16. W. Zhang, J. H. Rho, M. W. Roehrl, M. H. Roehrl, J. Y. Wang, A repertoire of 124 potential autoantigens for autoimmune kidney diseases identified by dermatan sulfate affinity enrichment of kidney tissue proteins. PLoS One 14, e0219018 (2019).

17. J. Lee, J.-h. Rho, M. H. Roehrl, J. Y. Wang, Dermatan Sulfate Is a Potential Master Regulator of IgH via Interactions with Pre-BCR, GTF2I, and BiP ER Complex in Pre-B Lymphoblasts. bioRxiv : the preprint server for biology, 2021.2001.2018.427153 (2021).

18. J. Y. Wang, W. Zhang, J. H. Rho, M. W. Roehrl, M. H. Roehrl, A proteomic repertoire of autoantigens identified from the classic autoantibody clinical test substrate HEp-2 cells. Clinical proteomics 17, 35 (2020).

19. S. Zhou, E. C. Jones-Lopez, D. J. Soneji, C. J. Azevedo, V. R. Patel, Myelin Oligodendrocyte Glycoprotein Antibody-Associated Optic Neuritis and Myelitis in COVID-19. Journal of neuroophthalmology : the official journal of the North American Neuro-Ophthalmology Society 40, 398402 (2020).

20. L. Bowles, S. Platton, N. Yartey, M. Dave, K. Lee, D. P. Hart, V. MacDonald, L. Green, S. Sivapalaratnam, K. J. Pasi, P. MacCallum, Lupus Anticoagulant and Abnormal Coagulation Tests in Patients with Covid-19. N Engl J Med 383, 288-290 (2020).

21. C. N. Gruber, R. S. Patel, R. Trachtman, L. Lepow, F. Amanat, F. Krammer, K. M. Wilson, K. Onel, D. Geanon, K. Tuballes, M. Patel, K. Mouskas, T. O'Donnell, E. Merritt, N. W. Simons, V. Barcessat, D. M. Del Valle, S. Udondem, G. Kang, S. Gangadharan, G. Ofori-Amanfo, U. Laserson, A. Rahman, S. Kim-Schulze, A. W. Charney, S. Gnjatic, B. D. Gelb, M. Merad, D. Bogunovic, Mapping Systemic Inflammation and Antibody Responses in Multisystem Inflammatory Syndrome in Children (MIS-C). Cell 183, 982-995.e914 (2020).

22. D. Gagiannis, J. Steinestel, C. Hackenbroch, B. Schreiner, M. Hannemann, W. Bloch, V. G. Umathum, N. Gebauer, C. Rother, M. Stahl, H. M. Witte, K. Steinestel, Clinical, Serological, and Histopathological Similarities Between Severe COVID-19 and Acute Exacerbation of Connective Tissue Disease-Associated Interstitial Lung Disease (CTD-ILD). Front Immunol 11, 587517 (2020).

23. L. A. Lerma, A. Chaudhary, A. Bryan, C. Morishima, M. H. Wener, S. L. Fink, Prevalence of autoantibody responses in acute coronavirus disease 2019 (COVID-19). Journal of translational autoimmunity 3, 100073 (2020).

24. H. Fujii, T. Tsuji, T. Yuba, S. Tanaka, Y. Suga, A. Matsuyama, A. Omura, S. Shiotsu, C. Takumi, S. Ono, M. Horiguchi, N. Hiraoka, High levels of anti-SSA/Ro antibodies in COVID-19 patients with severe respiratory failure: a case-based review : High levels of anti-SSA/Ro antibodies in COVID-19. Clin Rheumatol 39, 3171-3175 (2020).

25. D. Dragonetti, G. Guarini, M. Pizzuti, Detection of anti-heparin-PF4 complex antibodies in COVID-19 patients on heparin therapy. Blood transfusion = Trasfusione del sangue 18, 328 (2020).

26. P. Bastard, L. B. Rosen, Q. Zhang, E. Michailidis, H. H. Hoffmann, Y. Zhang, K. Dorgham, Q. Philippot, J. Rosain, V. Béziat, J. Manry, E. Shaw, L. Haljasmägi, P. Peterson, L. Lorenzo, L. Bizien, S. TrouilletAssant, K. Dobbs, A. A. de Jesus, A. Belot, A. Kallaste, E. Catherinot, Y. Tandjaoui-Lambiotte, J. Le Pen, G. Kerner, B. Bigio, Y. Seeleuthner, R. Yang, A. Bolze, A. N. Spaan, O. M. Delmonte, M. S. Abers, A. Aiuti, G. Casari, V. Lampasona, L. Piemonti, F. Ciceri, K. Bilguvar, R. P. Lifton, M. Vasse, D. M. Smadja, M. Migaud, J. Hadjadj, B. Terrier, D. Duffy, L. Quintana-Murci, D. van de Beek, L. Roussel, D. C. Vinh, S. G. Tangye, F. Haerynck, D. Dalmau, J. Martinez-Picado, P. Brodin, M. C. Nussenzweig, S. Boisson-Dupuis, C. Rodríguez-Gallego, G. Vogt, T. H. Mogensen, A. J. Oler, J. Gu, P. D. Burbelo, J. I. Cohen, A. Biondi, L. R. Bettini, M. D'Angio, P. Bonfanti, P. Rossignol, J. Mayaux, F. Rieux-Laucat, E. S. Husebye, F. Fusco, M. V. Ursini, L. Imberti, A. Sottini, S. Paghera, E. Quiros-Roldan, C. Rossi, R. Castagnoli, D. Montagna, A. Licari, G. L. Marseglia, X. Duval, J. Ghosn, J. S. Tsang, R. GoldbachMansky, K. Kisand, M. S. Lionakis, A. Puel, S. Y. Zhang, S. M. Holland, G. Gorochov, E. Jouanguy, C. 
M. Rice, A. Cobat, L. D. Notarangelo, L. Abel, H. C. Su, J. L. Casanova, Autoantibodies against type I IFNs in patients with life-threatening COVID-19. Science (New York, N.Y.) 370, (2020).

27. J. Kreye, S. M. Reincke, H. C. Kornau, E. Sánchez-Sendin, V. M. Corman, H. Liu, M. Yuan, N. C. Wu, X. Zhu, C. D. Lee, J. Trimpert, M. Höltje, K. Dietert, L. Stöffler, N. von Wardenburg, S. van Hoof, M. A. Homeyer, J. Hoffmann, A. Abdelgawad, A. D. Gruber, L. D. Bertzbach, D. Vladimirova, L. Y. Li, P. C. Barthel, K. Skriner, A. C. Hocke, S. Hippenstiel, M. Witzenrath, N. Suttorp, F. Kurth, C. Franke, M. Endres, D. Schmitz, L. M. Jeworowski, A. Richter, M. L. Schmidt, T. Schwarz, M. A. Müller, C. Drosten, D. Wendisch, L. E. Sander, N. Osterrieder, I. A. Wilson, H. Prüss, A Therapeutic Non-self-reactive SARS-CoV-2 Antibody Protects from Lung Pathology in a COVID-19 Hamster Model. Cell 183, 10581069.e1019 (2020).

28. Y. Zhou, B. Zhou, L. Pache, M. Chang, A. H. Khodabakhshi, O. Tanaseichuk, C. Benner, S. K. Chanda, Metascape provides a biologist-oriented resource for the analysis of systems-level datasets. Nat Commun 10, 1523 (2019).

29. J. Y. Zhang, X. M. Wang, X. Xing, Z. Xu, C. Zhang, J. W. Song, X. Fan, P. Xia, J. L. Fu, S. Y. Wang, R. N. Xu, X. P. Dai, L. Shi, L. Huang, T. J. Jiang, M. Shi, Y. Zhang, A. Zumla, M. Maeurer, F. Bai, F. S. Wang, Single-cell landscape of immunological responses in patients with COVID-19. Nat Immuno/ 21, 11071118 (2020).

30. J. P. Davies, K. M. Almasy, E. F. McDonald, L. Plate, Comparative Multiplexed Interactomics of SARSCoV-2 and Homologous Coronavirus Nonstructural Proteins Identifies Unique and Shared Host-Cell Dependencies. ACS infectious diseases 6, 3174-3189 (2020).

31. K. Klann, D. Bojkova, G. Tascher, S. Ciesek, C. Münch, J. Cinatl, Growth Factor Receptor Signaling Inhibition Prevents SARS-CoV-2 Replication. Molecular cell 80, 164-174.e164 (2020).

32. J. Sun, F. Ye, A. Wu, R. Yang, M. Pan, J. Sheng, W. Zhu, L. Mao, M. Wang, Z. Xia, B. Huang, W. Tan, T. Jiang, Comparative Transcriptome Analysis Reveals the Intensive Early Stage Responses of Host Cells to SARS-CoV-2 Infection. Frontiers in microbiology 11, 593857 (2020).

33. D. Bojkova, K. Klann, B. Koch, M. Widera, D. Krause, S. Ciesek, J. Cinatl, C. Münch, Proteomics of SARS-CoV-2-infected host cells reveals therapy targets. Nature 583, 469-472 (2020).

34. A. J. Wilk, A. Rustagi, N. Q. Zhao, J. Roque, G. J. Martínez-Colón, J. L. McKechnie, G. T. Ivison, T. Ranganath, R. Vergara, T. Hollis, L. J. Simpson, P. Grant, A. Subramanian, A. J. Rogers, C. A. Blish, A single-cell atlas of the peripheral immune response in patients with severe COVID-19. Nature medicine 26, 1070-1076 (2020).

35. N. A. P. Lieberman, V. Peddu, H. Xie, L. Shrestha, M. L. Huang, M. C. Mears, M. N. Cajimat, D. A. Bente, P. Y. Shi, F. Bovier, P. Roychoudhury, K. R. Jerome, A. Moscona, M. Porotto, A. L. Greninger, In vivo antiviral host transcriptional response to SARS-CoV-2 by viral load, sex, and age. PLoS biology 18, e3000849 (2020).

36. L. Riva, S. Yuan, X. Yin, L. Martin-Sancho, N. Matsunaga, L. Pache, S. Burgstaller-Muehlbacher, P. D. De Jesus, P. Teriete, M. V. Hull, M. W. Chang, J. F. Chan, J. Cao, V. K. Poon, K. M. Herbert, K. Cheng, T. H. Nguyen, A. Rubanov, Y. Pu, C. Nguyen, A. Choi, R. Rathnasinghe, M. Schotsaert, L. Miorin, M. Dejosez, T. P. Zwaka, K. Y. Sit, L. Martinez-Sobrido, W. C. Liu, K. M. White, M. E. Chapman, E. K. Lendy, R. J. Glynne, R. Albrecht, E. Ruppin, A. D. Mesecar, J. R. Johnson, C. Benner, R. Sun, P. G. Schultz, A. I. Su, A. García-Sastre, A. K. Chatterjee, K. Y. Yuen, S. K. Chanda, Discovery of SARS-CoV2 antiviral drugs through large-scale compound repurposing. Nature 586, 113-119 (2020).

37. M. Bouhaddou, D. Memon, B. Meyer, K. M. White, V. V. Rezelj, M. Correa Marrero, B. J. Polacco, J. E. Melnyk, S. Ulferts, R. M. Kaake, J. Batra, A. L. Richards, E. Stevenson, D. E. Gordon, A. Rojc, K. Obernier, J. M. Fabius, M. Soucheray, L. Miorin, E. Moreno, C. Koh, Q. D. Tran, A. Hardy, R. Robinot, T. Vallet, B. E. Nilsson-Payant, C. Hernandez-Armenta, A. Dunham, S. Weigang, J. Knerr, M. Modak, D. Quintero, Y. Zhou, A. Dugourd, A. Valdeolivas, T. Patil, Q. Li, R. Hüttenhain, M. Cakir, M. Muralidharan, M. Kim, G. Jang, B. Tutuncuoglu, J. Hiatt, J. Z. Guo, J. Xu, S. Bouhaddou, C. J. P. Mathy, 
A. Gaulton, E. J. Manners, E. Félix, Y. Shi, M. Goff, J. K. Lim, T. McBride, M. C. O'Neal, Y. Cai, J. C. J. Chang, D. J. Broadhurst, S. Klippsten, E. De Wit, A. R. Leach, T. Kortemme, B. Shoichet, M. Ott, J. Saez-Rodriguez, B. R. tenOever, R. D. Mullins, E. R. Fischer, G. Kochs, R. Grosse, A. García-Sastre, M. Vignuzzi, J. R. Johnson, K. M. Shokat, D. L. Swaney, P. Beltrao, N. J. Krogan, The Global Phosphorylation Landscape of SARS-CoV-2 Infection. Cell 182, 685-712.e619 (2020).

38. D. Blanco-Melo, B. E. Nilsson-Payant, W. C. Liu, S. Uhl, D. Hoagland, R. Møller, T. X. Jordan, K. Oishi, M. Panis, D. Sachs, T. T. Wang, R. E. Schwartz, J. K. Lim, R. A. Albrecht, B. R. tenOever, Imbalanced Host Response to SARS-CoV-2 Drives Development of COVID-19. Cell 181, 1036-1045.e1039 (2020).

39. B. Shen, X. Yi, Y. Sun, X. Bi, J. Du, C. Zhang, S. Quan, F. Zhang, R. Sun, L. Qian, W. Ge, W. Liu, S. Liang, H. Chen, Y. Zhang, J. Li, J. Xu, Z. He, B. Chen, J. Wang, H. Yan, Y. Zheng, D. Wang, J. Zhu, Z. Kong, Z. Kang, X. Liang, X. Ding, G. Ruan, N. Xiang, X. Cai, H. Gao, L. Li, S. Li, Q. Xiao, T. Lu, Y. Zhu, H. Liu, H. Chen, T. Guo, Proteomic and Metabolomic Characterization of COVID-19 Patient Sera. Cell 182, 5972.e15 (2020).

40. M. M. Lamers, J. Beumer, J. van der Vaart, K. Knoops, J. Puschhof, T. I. Breugem, R. B. G. Ravelli, J. Paul van Schayck, A. Z. Mykytyn, H. Q. Duimel, E. van Donselaar, S. Riesebosch, H. J. H. Kuijpers, D. Schipper, W. J. van de Wetering, M. de Graaf, M. Koopmans, E. Cuppen, P. J. Peters, B. L. Haagmans, H. Clevers, SARS-CoV-2 productively infects human gut enterocytes. Science (New York, N.Y.) 369, 50-54 (2020).

41. D. E. Gordon, G. M. Jang, M. Bouhaddou, J. Xu, K. Obernier, K. M. White, M. J. O'Meara, V. V. Rezelj, J. Z. Guo, D. L. Swaney, T. A. Tummino, R. Hüttenhain, R. M. Kaake, A. L. Richards, B. Tutuncuoglu, H. Foussard, J. Batra, K. Haas, M. Modak, M. Kim, P. Haas, B. J. Polacco, H. Braberg, J. M. Fabius, M. Eckhardt, M. Soucheray, M. J. Bennett, M. Cakir, M. J. McGregor, Q. Li, B. Meyer, F. Roesch, T. Vallet, A. Mac Kain, L. Miorin, E. Moreno, Z. Z. C. Naing, Y. Zhou, S. Peng, Y. Shi, Z. Zhang, W. Shen, I. T. Kirby, J. E. Melnyk, J. S. Chorba, K. Lou, S. A. Dai, I. Barrio-Hernandez, D. Memon, C. HernandezArmenta, J. Lyu, C. J. P. Mathy, T. Perica, K. B. Pilla, S. J. Ganesan, D. J. Saltzberg, R. Rakesh, X. Liu, S. B. Rosenthal, L. Calviello, S. Venkataramanan, J. Liboy-Lugo, Y. Lin, X. P. Huang, Y. Liu, S. A. Wankowicz, M. Bohn, M. Safari, F. S. Ugur, C. Koh, N. S. Savar, Q. D. Tran, D. Shengjuler, S. J. Fletcher, M. C. O'Neal, Y. Cai, J. C. J. Chang, D. J. Broadhurst, S. Klippsten, P. P. Sharp, N. A. Wenzell, D. Kuzuoglu-Ozturk, H. Y. Wang, R. Trenker, J. M. Young, D. A. Cavero, J. Hiatt, T. L. Roth, U. Rathore, A. Subramanian, J. Noack, M. Hubert, R. M. Stroud, A. D. Frankel, O. S. Rosenberg, K. A. Verba, D. A. Agard, M. Ott, M. Emerman, N. Jura, M. von Zastrow, E. Verdin, A. Ashworth, O. Schwartz, C. d'Enfert, S. Mukherjee, M. Jacobson, H. S. Malik, D. G. Fujimori, T. Ideker, C. S. Craik, S. N. Floor, J. S. Fraser, J. D. Gross, A. Sali, B. L. Roth, D. Ruggero, J. Taunton, T. Kortemme, P. Beltrao, M. Vignuzzi, A. García-Sastre, K. M. Shokat, B. K. Shoichet, N. J. Krogan, A SARS-CoV-2 protein interaction map reveals targets for drug repurposing. Nature 583, 459-468 (2020).

42. Y. Xiong, Y. Liu, L. Cao, D. Wang, M. Guo, A. Jiang, D. Guo, W. Hu, J. Yang, Z. Tang, H. Wu, Y. Lin, M. Zhang, Q. Zhang, M. Shi, Y. Liu, Y. Zhou, K. Lan, Y. Chen, Transcriptomic characteristics of bronchoalveolar lavage fluid and peripheral blood mononuclear cells in COVID-19 patients. Emerging microbes \& infections 9, 761-770 (2020).

43. A. Vanderheiden, P. Ralfs, T. Chirkova, A. A. Upadhyay, M. G. Zimmerman, S. Bedoya, H. Aoued, G. M. Tharp, K. L. Pellegrini, C. Manfredi, E. Sorscher, B. Mainou, J. L. Lobby, J. E. Kohlmeier, A. C. Lowen, P. Y. Shi, V. D. Menachery, L. J. Anderson, A. Grakoui, S. E. Bosinger, M. S. Suthar, Type I and Type III Interferons Restrict SARS-CoV-2 Infection of Human Airway Epithelial Cultures. Journal of virology 94, (2020).

44. S. Appelberg, S. Gupta, S. Svensson Akusjärvi, A. T. Ambikan, F. Mikaeloff, E. Saccon, Á. Végvári, R. Benfeitas, M. Sperk, M. Ståhlberg, S. Krishnan, K. Singh, J. M. Penninger, A. Mirazimi, U. Neogi, Dysregulation in Akt/mTOR/HIF-1 signaling identified by proteo-transcriptomics of SARS-CoV-2 infected cells. Emerging microbes \& infections 9, 1748-1760 (2020). 
45. A. Stukalov, V. Girault, V. Grass, V. Bergant, O. Karayel, C. Urban, D. A. Haas, Y. Huang, L. Oubraham, A. Wang, S. M. Hamad, A. Piras, M. Tanzer, F. M. Hansen, T. Enghleitner, M. Reinecke, T. M. Lavacca, R. Ehmann, R. Wölfel, J. Jores, B. Kuster, U. Protzer, R. Rad, J. Ziebuhr, V. Thiel, P. Scaturro, M. Mann, A. Pichlmair, Multi-level proteomics reveals host-perturbation strategies of SARS-CoV-2 and SARSCoV. bioRxiv : the preprint server for biology, 2020.2006.2017.156455 (2020).

46. W. Emanuel, M. Kirstin, F. Vedran, D. Asija, G. L. Theresa, A. Roberto, K. Filippos, K. David, A. Salah, B. Christopher, R. Anja, L. Ivano, I. Andranik, M. Tommaso, D. G. Simone, P. J. Patrick, M. M. Alexander, N. Daniela, S. Matthias, A. Altuna, R. Nikolaus, D. Christian, L. Markus, Bulk and singlecell gene expression profiling of SARS-CoV-2 infected human cell lines identifies molecular targets for therapeutic intervention. bioRxiv : the preprint server for biology, 2020.2005.2005.079194 (2020).

47. Y. Li, Y. Wang, H. Liu, W. Sun, B. Ding, Y. Zhao, P. Chen, L. Zhu, Z. Li, N. Li, L. Chang, H. Wang, C. Bai, P. Xu, Urine Proteome of COVID-19 Patients. medRxiv, 2020.2005.2002.20088666 (2020).

48. M. Liao, Y. Liu, J. Yuan, Y. Wen, G. Xu, J. Zhao, L. Cheng, J. Li, X. Wang, F. Wang, L. Liu, I. Amit, S. Zhang, Z. Zhang, Single-cell landscape of bronchoalveolar immune cells in patients with COVID-19. Nature medicine 26, 842-844 (2020).

49. M. Absi, J. P. La Vergne, A. Marzouki, F. Giraud, D. Rigal, A. M. Reboud, J. P. Reboud, J. C. Monier, Heterogeneity of ribosomal autoantibodies from human, murine and canine connective tissue diseases. Immunol Lett 23, 35-41 (1989).

50. E. Feist, U. Kuckelkorn, T. Dorner, H. Donitz, S. Scheffler, F. Hiepe, P. M. Kloetzel, G. R. Burmester, Autoantibodies in primary Sjogren's syndrome are directed against proteasomal subunits of the alpha and beta type. Arthritis Rheum 42, 697-702 (1999).

51. D. Szklarczyk, A. L. Gable, D. Lyon, A. Junge, S. Wyder, J. Huerta-Cepas, M. Simonovic, N. T. Doncheva, J. H. Morris, P. Bork, L. J. Jensen, C. V. Mering, STRING v11: protein-protein association networks with increased coverage, supporting functional discovery in genome-wide experimental datasets. Nucleic Acids Res 47, D607-d613 (2019).

52. A. Estrada-Bernal, S. D. Sanford, L. J. Sosa, G. C. Simon, K. C. Hansen, K. H. Pfenninger, Functional complexity of the axonal growth cone: a proteomic analysis. PLoS One 7, e31858 (2012).

53. M. Wille, A. Schümann, M. Kreutzer, M. O. Glocker, A. Wree, G. Mutzbauer, O. Schmitt, The proteome profiles of the olfactory bulb of juvenile, adult and aged rats - an ontogenetic study. Proteome science 13, 8 (2015).

54. N. Sengupta, S. Ghosh, S. V. Vasaikar, J. Gomes, A. Basu, Modulation of neuronal proteome profile in response to Japanese encephalitis virus infection. PLoS One 9, e90211 (2014).

55. W. Rozek, M. Kwasnik, J. Debski, J. F. Zmudzinski, Mass spectrometry identification of granins and other proteins secreted by neuroblastoma cells. Tumour biology : the journal of the International Society for Oncodevelopmental Biology and Medicine 34, 1773-1781 (2013).

56. D. M. Mallawaaratchy, S. Hallal, B. Russell, L. Ly, S. Ebrahimkhani, H. Wei, R. I. Christopherson, M. E. Buckland, K. L. Kaufman, Comprehensive proteome profiling of glioblastoma-derived extracellular vesicles identifies markers for more aggressive disease. Journal of neuro-oncology 131, 233-244 (2017).

57. M. Perluigi, F. Di Domenico, D. A. Buttterfield, Unraveling the complexity of neurodegeneration in brains of subjects with Down syndrome: insights from proteomics. Proteomics Clin Appl 8, 73-85 (2014).

58. S. Ayyadevara, M. Balasubramaniam, P. A. Parcon, S. W. Barger, W. S. Griffin, R. Alla, A. J. Tackett, S. G. Mackintosh, E. Petricoin, W. Zhou, R. J. Shmookler Reis, Proteins that mediate protein aggregation and cytotoxicity distinguish Alzheimer's hippocampus from normal controls. Aging cell 15, 924-939 (2016). 
59. K. Davalieva, I. Maleva Kostovska, A. J. Dwork, Proteomics Research in Schizophrenia. Frontiers in cellular neuroscience 10, 18 (2016).

60. A. Kahl, I. Blanco, K. Jackman, J. Baskar, H. Milaganur Mohan, R. Rodney-Sandy, S. Zhang, C. Iadecola, K. Hochrainer, Cerebral ischemia induces the aggregation of proteins linked to neurodegenerative diseases. Sci Rep 8, 2701 (2018).

61. M. Repici, M. Hassanjani, D. C. Maddison, P. Garção, S. Cimini, B. Patel, M. Szegö É, K. R. Straatman, K. S. Lilley, T. Borsello, T. F. Outeiro, L. Panman, F. Giorgini, The Parkinson's Disease-Linked Protein DJ-1 Associates with Cytoplasmic mRNP Granules During Stress and Neurodegeneration. Molecular neurobiology 56, 61-77 (2019).

62. M. T. McMillan, X. Q. Pan, A. L. Smith, D. K. Newman, S. R. Weiss, M. R. Ruggieri, Sr., A. P. Malykhina, Coronavirus-induced demyelination of neural pathways triggers neurogenic bladder overactivity in a mouse model of multiple sclerosis. American journal of physiology. Renal physiology 307, F612622 (2014).

63. H. P. Li, Y. Komuta, J. Kimura-Kuroda, T. H. van Kuppevelt, H. Kawano, Roles of chondroitin sulfate and dermatan sulfate in the formation of a lesion scar and axonal regeneration after traumatic injury of the mouse brain. Journal of neurotrauma 30, 413-425 (2013).

64. R. A. Sobel, A. S. Ahmed, White matter extracellular matrix chondroitin sulfate/dermatan sulfate proteoglycans in multiple sclerosis. Journal of neuropathology and experimental neurology 60, 1198-1207 (2001).

65. C. Ogura, K. Hirano, S. Mizumoto, S. Yamada, S. Nishihara, Dermatan sulfate promotes neuronal differentiation in mouse and human stem cells. Journal of biochemistry, (2020).

66. A. I. S. Sobczak, S. J. Pitt, A. J. Stewart, Glycosaminoglycan Neutralization in Coagulation Control. Arteriosclerosis, thrombosis, and vascular biology 38, 1258-1270 (2018).

67. Y. Li, J. Wu, S. Wang, X. Li, J. Zhou, B. Huang, D. Luo, Q. Cao, Y. Chen, S. Chen, L. Ma, L. Peng, H. Pan, W. D. Travis, X. Nie, Progression to fibrosing diffuse alveolar damage in a series of 30 minimally invasive autopsies with COVID-19 pneumonia in Wuhan, China. Histopathology, (2020).

68. J. Wigén, A. Löfdahl, L. Bjermer, L. Elowsson-Rendin, G. Westergren-Thorsson, Converging pathways in pulmonary fibrosis and Covid-19 - The fibrotic link to disease severity. Respiratory medicine: $X \mathbf{2}$, 100023 (2020).

69. K. J. Smith, H. G. Skelton, W. Heimer, D. Baxter, P. Angritt, D. Frisman, K. F. Wagner, Melanocytic activation in HIV-1 disease: HMB-45 staining in common acquired nevi. Military Medical Consortium for the Advancement of Retroviral Research. Journal of the American Academy of Dermatology 29, 539-544 (1993).

70. R. Boostani, F. R. Talab, N. T. Meibodi, F. Zemorshidi, COVID-19 associated with sensorimotor polyradiculoneuropathy and skin lesions: A case report. J Neuroimmunol 350, 577434 (2020).

71. J. J. Hooks, C. Percopo, Y. Wang, B. Detrick, Retina and retinal pigment epithelial cell autoantibodies are produced during murine coronavirus retinopathy. J Immunol 151, 3381-3389 (1993).

72. M. Cortese, J. Y. Lee, B. Cerikan, C. J. Neufeldt, V. M. J. Oorschot, S. Köhrer, J. Hennies, N. L. Schieber, P. Ronchi, G. Mizzon, I. Romero-Brey, R. Santarella-Mellwig, M. Schorb, M. Boermel, K. Mocaer, M. S. Beckwith, R. M. Templin, V. Gross, C. Pape, C. Tischer, J. Frankish, N. K. Horvat, V. Laketa, M. Stanifer, S. Boulant, A. Ruggieri, L. Chatel-Chaix, Y. Schwab, R. Bartenschlager, Integrative Imaging Reveals SARS-CoV-2-Induced Reshaping of Subcellular Morphologies. Cell host \& microbe 28, 853866.e855 (2020).

73. M. L. Ng, J. W. Lee, M. L. Leong, A. E. Ling, H. C. Tan, E. E. Ooi, Topographic changes in SARS coronavirus-infected cells at late stages of infection. Emerging infectious diseases 10, 1907-1914 (2004).

74. R. E. Lloyd, Nuclear proteins hijacked by mammalian cytoplasmic plus strand RNA viruses. Virology 479-480, 457-474 (2015). 
75. Z. Chen, S. Liu, S. Zhang, Y. Zhang, J. Yu, W. Sun, L. Chen, Y. Du, J. Wang, Y. Li, J. Wu, Porcine Reproductive and Respiratory Syndrome Virus strains with Higher Virulence Cause Marked Protein Profile Changes in MARC-145 Cells. Sci Rep 8, 15000 (2018).

76. Y. Li, F. Ming, H. Huang, K. Guo, H. Chen, M. Jin, H. Zhou, Proteome Response of Chicken Embryo Fibroblast Cells to Recombinant H5N1 Avian Influenza Viruses with Different Neuraminidase Stalk Lengths. Sci Rep 7, 40698 (2017).

77. E. Bortz, L. Westera, J. Maamary, J. Steel, R. A. Albrecht, B. Manicassamy, G. Chase, L. MartínezSobrido, M. Schwemmle, A. García-Sastre, Host- and strain-specific regulation of influenza virus polymerase activity by interacting cellular proteins. mBio 2, (2011).

78. J. E. Nuss, K. Kehn-Hall, A. Benedict, J. Costantino, M. Ward, B. D. Peyser, C. J. Retterer, L. E. Tressler, L. M. Wanner, H. F. McGovern, A. Zaidi, S. M. Anthony, K. P. Kota, S. Bavari, R. M. Hakami, Multifaceted proteomic characterization of host protein complement of Rift Valley fever virus virions and identification of specific heat shock proteins, including HSP90, as important viral host factors. PLoS One 9, e93483 (2014).

79. J. Yang, L. Yang, B. Li, W. Zhou, S. Zhong, Z. Zhuang, B. Yang, M. Chen, Q. Feng, iTRAQ-Based Proteomics Identification of Serum Biomarkers of Two Chronic Hepatitis B Subtypes Diagnosed by Traditional Chinese Medicine. BioMed research international 2016, 3290260 (2016).

80. É. Csősz, F. Tóth, M. Mahdi, G. Tsaprailis, M. Emri, J. Tőzsér, Analysis of networks of host proteins in the early time points following HIV transduction. BMC bioinformatics 20, 398 (2019).

81. A. Monette, N. Panté, A. J. Mouland, HIV-1 remodels the nuclear pore complex. The Journal of cell biology 193, 619-631 (2011).

82. M. Stake, D. Singh, G. Singh, J. Marcela Hernandez, R. Kaddis Maldonado, L. J. Parent, K. BorisLawrie, HIV-1 and two avian retroviral 5' untranslated regions bind orthologous human and chicken RNA binding proteins. Virology 486, 307-320 (2015).

83. S. Tada, M. Hamada, Y. Yura, Proteomic Analysis of Secretomes of Oncolytic Herpes Simplex VirusInfected Squamous Cell Carcinoma Cells. Cancers (Basel) 10, (2018).

84. M. R. Wilkes, S. M. Sereika, N. Fertig, M. R. Lucas, C. V. Oddis, Treatment of antisynthetaseassociated interstitial lung disease with tacrolimus. Arthritis Rheum 52, 2439-2446 (2005).

85. C. C. Bunn, R. M. Bernstein, M. B. Mathews, Autoantibodies against alanyl-tRNA synthetase and tRNAAla coexist and are associated with myositis. J Exp Med 163, 1281-1291 (1986).

86. J. Wu, K. C. V. Subbaiah, L. H. Xie, F. Jiang, E. S. Khor, D. Mickelsen, J. R. Myers, W. H. W. Tang, P. Yao, Glutamyl-Prolyl-tRNA Synthetase Regulates Proline-Rich Pro-Fibrotic Protein Synthesis During Cardiac Fibrosis. Circulation research 127, 827-846 (2020).

87. P. C. Tsai, B. W. Soong, I. Mademan, Y. H. Huang, C. R. Liu, C. T. Hsiao, H. T. Wu, T. T. Liu, Y. T. Liu, Y. T. Tseng, K. P. Lin, U. C. Yang, K. W. Chung, B. O. Choi, G. A. Nicholson, M. L. Kennerson, C. C. Chan, P. De Jonghe, T. H. Cheng, Y. C. Liao, S. Züchner, J. Baets, Y. C. Lee, A recurrent WARS mutation is a novel cause of autosomal dominant distal hereditary motor neuropathy. Brain : a journal of neurology 140, 1252-1266 (2017).

88. E. L. Paley, N. Alexandrova, L. Smelansky, Tryptophanyl-tRNA synthetase as a human autoantigen. Immunol Lett 48, 201-207 (1995).

89. S. X. Ge, D. Jung, R. Yao, ShinyGO: a graphical gene-set enrichment tool for animals and plants. Bioinformatics (Oxford, England) 36, 2628-2629 (2020). 
bioRxiv preprint doi: https://doi.org/10.1101/2021.01.24.427965; this version posted January 24, 2021. The copyright holder for this preprint (which was not certified by peer review) is the author/funder, who has granted bioRxiv a license to display the preprint in perpetuity. It is made available under aCC-BY 4.0 International license.

Table 1. DS-affinity enriched autoantigenome from human HFL1 cells

\begin{tabular}{|c|c|c|c|c|c|c|c|}
\hline \multirow{2}{*}{$\begin{array}{c}\# \\
\text { Pep. }\end{array}$} & \multirow{2}{*}{ Gene } & \multirow{2}{*}{ Protein } & \multicolumn{2}{|c|}{ COVID } & \multicolumn{2}{|c|}{$\begin{array}{c}\text { DS } \\
\text { affinity }\end{array}$} & \multirow{2}{*}{ Ref. } \\
\hline & & & Up & Down & $\begin{array}{c}1.0 \\
M\end{array}$ & $\begin{array}{l}0.5 \\
M\end{array}$ & \\
\hline 5 & A2M & Alpha-2-macroglobulin & & $\mathrm{D}$ & & + & (1) \\
\hline 5 & AARS & Alanyl-tRNA synthetase, cytoplasmic & $\mathrm{U}$ & $\mathrm{D}$ & & + & (2) \\
\hline 10 & ACTA2 & Actin, aortic smooth muscle & $U$ & $\mathrm{D}$ & & + & (3) \\
\hline 8 & ACTB & Actin, cytoplasmic & $U$ & $\mathrm{D}$ & & + & (4) \\
\hline 6 & ACTBL2 & Beta-actin-like protein & U & $\mathrm{D}$ & & + & \\
\hline 17 & ACTN1 & Alpha-actinin-1 & $\mathrm{U}$ & $\mathrm{D}$ & & + & (5) \\
\hline 6 & ACTN4 & Alpha-actinin-4 & U & $\mathrm{D}$ & & + & (3) \\
\hline 3 & AFP & Alpha-fetoprotein & & $\mathrm{D}$ & & + & (6) \\
\hline 5 & AHNAK & Neuroblast differentiation-associated protein & $U$ & $\mathrm{D}$ & & + & $(7)$ \\
\hline 10 & ALB & Putative uncharacterized protein albumin & $U$ & $\mathrm{D}$ & & + & $(8)$ \\
\hline 3 & ALPP & Alkaline phosphatase, placental type precursor & & & + & & (9) \\
\hline 6 & ANP32A & Acidic leucine-rich nuclear phosphoprotein 32 member A & $\mathrm{U}$ & $\mathrm{D}$ & + & & \\
\hline 11 & ANP32B & Acidic nuclear phosphoprotein 32 family member B & & $\mathrm{D}$ & + & & \\
\hline 3 & ANP32C & Acidic nuclear phosphoprotein 32 family member $\mathrm{C}$ & & & + & & \\
\hline 3 & ANP32E & Acidic nuclear phosphoprotein 32 family member $\mathrm{E}$ & $U$ & $\mathrm{D}$ & + & & \\
\hline 2 & ANXA2 & Annexin A2 & U & $\mathrm{D}$ & + & & (10) \\
\hline 7 & ANXA2P2 & Putative annexin A2-like protein, ANX2L2, LPC2B & $U$ & $\mathrm{D}$ & & + & \\
\hline 7 & ANXA5 & Annexin A5 & $\mathrm{U}$ & $\mathrm{D}$ & & + & (11) \\
\hline 33 & ANXA6 & Annexin VI & $U$ & $\mathrm{D}$ & & + & (12) \\
\hline 2 & AP1B1 & AP-1 complex subunit beta-1 & & & & + & \\
\hline 2 & AP3B1 & AP-3 complex subunit beta-1 & $\mathrm{U}$ & & + & & \\
\hline 2 & AP3B2 & AP-3 complex subunit beta-2 & & & + & & (13) \\
\hline 3 & AP3D1 & AP-3 complex subunit delta-1 & $U$ & $\mathrm{D}$ & + & & \\
\hline 3 & APOA1 & Apolipoprotein A-I & & $\mathrm{D}$ & & + & (14) \\
\hline 2 & APOD & Apolipoprotein D & $U$ & $\mathrm{D}$ & & + & \\
\hline 2 & ARCN1 & Coatomer delta, Archain vesicle transport protein 1 & & $\mathrm{D}$ & & + & \\
\hline 4 & ARF1 & ADP-ribosylation factor & & & & + & \\
\hline 2 & ARHGAP1 & Rho-GTPase-activating protein & $U$ & & & + & \\
\hline 4 & ARHGDIA & Rho GDP-dissociation inhibitor 1 & $U$ & $\mathrm{D}$ & & + & \\
\hline 9 & ATP5B & ATP synthase subunit beta, ATP5F1B & $\mathrm{U}$ & $\mathrm{D}$ & & + & (15) \\
\hline 3 & BCAT1 & Branched chain amino acid aminotransferase & $U$ & & & + & \\
\hline 2 & BCCIP & BRCA2 and CDKN1A-interacting protein & & & & + & \\
\hline 2 & BGN & Biglycan & & & + & & (16) \\
\hline 2 & BSG & Basigin, CD147 & & $\mathrm{D}$ & + & & (17) \\
\hline 2 & BZW2 & Basic leucine zipper and W2 domains 2 & & & & + & \\
\hline 7 & C1QBP & Complement C1q-binding protein & & $\mathrm{D}$ & + & & (18) \\
\hline 7 & CALD1 & Caldesmon & & $\mathrm{D}$ & & + & \\
\hline 8 & CALM1 & CALM3; CALM2 Calmodulin & $U$ & $\mathrm{D}$ & & + & (19) \\
\hline 16 & CALR & Calreticulin & $U$ & $\mathrm{D}$ & & + & $(20)$ \\
\hline 2 & CALU & Calumenin & $\mathrm{U}$ & $\mathrm{D}$ & & + & $(21)$ \\
\hline 3 & CANX & Calnexin & $\mathrm{U}$ & $\mathrm{D}$ & + & & (22) \\
\hline 9 & CAP1 & Adenylyl cyclase-associated protein & $U$ & $\mathrm{D}$ & & + & \\
\hline 7 & CAPN1 & Calpain-1 catalytic subunit & & & & + & \\
\hline 5 & CAPN2 & Calpain-2 catalytic subunit & $\mathrm{U}$ & $\mathrm{D}$ & & + & (19) \\
\hline 3 & CAPNS1 & Calpain small subunit & & & & + & \\
\hline 2 & CAPZA1 & F-actin-capping protein subunit alpha-1 & & $\mathrm{D}$ & + & & (23) \\
\hline 3 & CAPZB & F-actin-capping protein subunit beta & & $\mathrm{D}$ & & + & (24) \\
\hline 8 & CAVIN1 & Caveolae-associated protein 1 , PTRF & $U$ & $\mathrm{D}$ & & + & \\
\hline 3 & CBX1 & Chromobox protein homolog & $U$ & & & + & (25) \\
\hline 3 & CCDC6 & Coiled-coil domain-containing protein & $U$ & $\mathrm{D}$ & & + & $(26)$ \\
\hline 3 & CCT2 & T-complex protein 1 subunit beta & & $\mathrm{D}$ & & + & \\
\hline 3 & ССТ8 & T-complex protein 1 subunit theta & $U$ & $\mathrm{D}$ & & + & (27) \\
\hline 4 & CD248 & Endosialin & & $\mathrm{D}$ & & + & \\
\hline 5 & CDC37 & Hsp90 co-chaperone Cdc37 & $U$ & $\mathrm{D}$ & & + & \\
\hline 4 & CKAP4 & Cytoskeleton-associated protein 4, P63 & $U$ & $\mathrm{D}$ & + & & (28) \\
\hline 8 & CKB & Creatine kinase B-type & $U$ & $\mathrm{D}$ & & + & (29) \\
\hline 7 & CLIC1 & Chloride intracellular channel protein & $U$ & $\mathrm{D}$ & & + & \\
\hline 2 & CLIC4 & Chloride intracellular channel protein & $U$ & $\mathrm{D}$ & & + & \\
\hline 14 & CLTC & Clathrin heavy chain 1 & $U$ & $\mathrm{D}$ & + & & (30) \\
\hline 3 & CLTCL1 & Clathrin heavy chain 2 & & & + & & \\
\hline
\end{tabular}


bioRxiv preprint doi: https://doi.org/10.1101/2021.01.24.427965; this version posted January 24, 2021. The copyright holder for this preprint (which was not certified by peer review) is the author/funder, who has granted bioRxiv a license to display the preprint in perpetuity. It is made available under aCC-BY 4.0 International license.

\begin{tabular}{|c|c|c|c|c|c|c|c|}
\hline 3 & CNPY2 & Protein canopy homolog & & $\mathrm{D}$ & & + & \\
\hline 13 & COL12A1 & Collagen type XII alpha-1 chain & $\mathrm{U}$ & D & & + & \\
\hline 45 & COL1A1 & Collagen type I alpha-1 chain & $\mathrm{U}$ & D & & + & (31) \\
\hline 37 & COL1A2 & Collagen type I alpha-2 chain & & D & & + & (32) \\
\hline 2 & COL2A1 & Collagen type II alpha-1 chain & $\mathrm{U}$ & & & + & (33) \\
\hline 12 & COL3A1 & Collagen type III alpha-1 chain & & & & + & (34) \\
\hline 3 & COL5A1 & Collagen type $\mathrm{V}$ alpha 1 & $\mathrm{U}$ & & & + & (35) \\
\hline 6 & COL6A1 & Collagen type $\mathrm{VI}$ alpha-1 chain & & $\mathrm{D}$ & & + & (36) \\
\hline 4 & COL6A2 & Collagen type $\mathrm{VI}$ alpha-2 chain & & D & & + & \\
\hline 29 & COL6A3 & Collagen type VI alpha-3 chain & & D & & + & \\
\hline 2 & COPA & Coatomer subunit alpha & $\mathrm{U}$ & $\mathrm{D}$ & + & & (37) \\
\hline 2 & COPB1 & Coatomer subunit beta & & $\mathrm{D}$ & + & & (38) \\
\hline 5 & COPB2 & Coatomer subunit beta' & U & & + & & (39) \\
\hline 2 & COPZ1 & Coatomer subunit zeta-1 & & D & & + & \\
\hline 3 & CORO1C & Coronin-1C & & & & + & \\
\hline 4 & CRK & Proto-oncogene C-crk & U & D & & + & \\
\hline 5 & CRTAP & Cartilage-associated protein, $\mathrm{P} 3 \mathrm{H} 5$ & & D & + & & \\
\hline 4 & CSPG4 & Chondroitin sulfate proteoglycan 4 & & D & + & & (40) \\
\hline 3 & CTSB & Cathepsin B, APP secretase & U & D & & + & \\
\hline 2 & CTSD & Cathepsin D & $\mathrm{U}$ & D & & + & (41) \\
\hline 2 & CUTA & CutA divalent cation tolerance homolog & $\mathrm{U}$ & D & & + & \\
\hline 2 & DBN1 & Drebrin 1 & $\mathrm{U}$ & D & & + & (42) \\
\hline 3 & $\mathrm{DCN}$ & Decorin & & D & + & & (43) \\
\hline 2 & DCTN1 & Dynactin subunit 1, $150 \mathrm{KDa}$ Dynein-associated protein & & D & + & & (44) \\
\hline 5 & DCTN2 & Dynactin subunit 2 & & & & + & \\
\hline 12 & DDB1 & DNA damage-binding protein 1 & $\mathrm{U}$ & D & & + & (30) \\
\hline 2 & DDX39 & ATP-dependent RNA helicase DDX39A & $\mathrm{U}$ & D & & + & \\
\hline 5 & DDX39B & Spliceosome RNA helicase BAT1 & & D & & + & \\
\hline 5 & DHX15 & ATP-dependent RNA helicase \#46 & & D & + & & \\
\hline 5 & DHX9 & ATP-dependent RNA helicase A & & & + & & (45) \\
\hline 5 & DIABLO & Diablo, IAP (Inihibitor of apoptosis protein)-binding & $\mathrm{U}$ & & & + & \\
\hline 2 & DKC1 & H/ACA ribonucleoprotein complex subunit DKC1 & U & D & + & & \\
\hline 2 & DLST & $\begin{array}{l}\text { Dihydrolipoyllysine-residue succinyltransferase component of } \\
\text { 2- oxoglutarate dehydrogenase complex }\end{array}$ & & $\mathrm{D}$ & & + & $(46)$ \\
\hline 2 & DNAJB11 & DnaJ (Hsp40) homolog subfamily B member 11 & $\mathrm{U}$ & & & + & $(47)$ \\
\hline 2 & DPP3 & Dipeptidyl-peptidase 3 & & D & & + & \\
\hline 3 & DPYSL2 & Dihydropyrimidinase-related protein & $\mathrm{U}$ & $\mathrm{D}$ & & + & (48) \\
\hline 3 & DRG1 & Developmentally-regulated GTP-binding protein & & $\mathrm{D}$ & & + & \\
\hline 5 & DYNC1H1 & Dynein cytoplasmic 1 heavy chain 1 & & & + & & \\
\hline 2 & DYNC112 & Dynein cytoplasmic 1 intermediate chain 2 & & & + & & \\
\hline 2 & EEF1A1 & Elongation factor 1-alph 1 & $\mathrm{U}$ & $\mathrm{D}$ & & + & (49) \\
\hline 3 & EEF1A2 & Elongation factor 1-alpha 2 & $U$ & & & + & (50) \\
\hline 2 & EEF1B2 & Elongation factor 1-beta 2 & & $\mathrm{D}$ & & + & \\
\hline 5 & EEF1D & Elongation factor 1-delta & & $\mathrm{D}$ & & + & \\
\hline 10 & EEF1G & Elongation factor 1-gamma & $\mathrm{U}$ & $\mathrm{D}$ & & + & \\
\hline 14 & EEF2 & Elongation factor 2 & $\mathrm{U}$ & $\mathrm{D}$ & & + & (51) \\
\hline 6 & EFTUD2 & 116 kDa U5 snRNP component, SNRP116 & & $\mathrm{D}$ & + & & (52) \\
\hline 4 & EHD2 & EH domain-containing protein 2 & $\mathrm{U}$ & $\mathrm{D}$ & & + & \\
\hline 3 & EIF2S1 & Eukaryotic translation initiation factor 2 subunit 1, EIF2A & & & & + & (53) \\
\hline 10 & EIF3A & Eukaryotic translation initiation factor 3 subunit A & $\mathrm{U}$ & $\mathrm{D}$ & + & & (54) \\
\hline 9 & EIF3B & Eukaryotic translation initiation factor 3 subunit B & $\mathrm{U}$ & D & + & & \\
\hline 3 & EIF3CL & Eukaryotic translation initiation factor 3 subunit C-like protein & & $\mathrm{D}$ & + & & \\
\hline 5 & EIF3E & Eukaryotic translation initiation factor 3 subunit E & $\mathrm{U}$ & $\mathrm{D}$ & + & & (55) \\
\hline 2 & EIF3F & Eukaryotic translation initiation factor 3 subunit $F$ & $\mathrm{U}$ & D & + & & \\
\hline 2 & EIF3G & Eukaryotic translation initiation factor 3 subunit $\mathrm{G}$ & & & & + & \\
\hline 6 & EIF3L & EIF3, subunit E interacting protein & & D & + & & \\
\hline 11 & EIF4A1 & Eukaryotic initiation factor 4A-1, DDX2A & U & $\mathrm{D}$ & & + & \\
\hline 2 & EIF4A3 & Eukaryotic initiation factor 4A-III, DDX48 & & & & + & (56) \\
\hline 4 & EIF4G1 & Eukaryotic translation initiation factor 4 gamma 1 & $\mathrm{U}$ & $\mathrm{D}$ & & + & \\
\hline 2 & EIF4G2 & Eukaryotic translation initiation factor 4 gamma 2 & & D & & + & \\
\hline 4 & EIF5A & Eukaryotic translation initiation factor 5A-1 & U & D & & + & \\
\hline 2 & EIF5A2 & Eukaryotic translation initiation factor $5 \mathrm{~A}-2$ & & D & & + & \\
\hline 3 & EIF6 & Eukaryotic translation initiation factor 6 & U & & & + & \\
\hline 4 & ELAVL1 & ELAV-like protein & & D & & + & (57) \\
\hline 2 & ELOB & Transcription elongation factor B, TCEB2 & U & $\mathrm{D}$ & & + & \\
\hline 2 & ENO1 & Alpha-enolase & U & D & & + & (58) \\
\hline
\end{tabular}


bioRxiv preprint doi: https://doi.org/10.1101/2021.01.24.427965; this version posted January 24, 2021. The copyright holder for this preprint (which was not certified by peer review) is the author/funder, who has granted bioRxiv a license to display the preprint in perpetuity. It is made available under aCC-BY 4.0 International license.

\begin{tabular}{|c|c|c|c|c|c|c|c|}
\hline 7 & ENO2 & Gamma-enolase & $\mathrm{U}$ & D & & + & (59) \\
\hline 2 & ENOPH1 & Enolase-phosphatase E1 & $\mathrm{U}$ & & & + & \\
\hline 2 & EPRS & Bifunctional aminoacyl-tRNA synthetase, EPRS1 & $\mathrm{U}$ & & + & & (60) \\
\hline 6 & ERP44 & Endoplasmic reticulum resident protein ERp44 & & & & + & (61) \\
\hline 2 & EWSR1 & EWS RNA-binding protein & $\mathrm{U}$ & & & + & \\
\hline 2 & FAF1 & FAS-associated factor 1 & $\mathrm{U}$ & & & + & \\
\hline 4 & FAM62A & Extended synaptotagmin-1, ESYT1 & & & + & & (62) \\
\hline 2 & FASN & Fatty acid synthase & $\mathrm{U}$ & D & & + & (63) \\
\hline 3 & FBLN1 & Fibulin 1 & $\mathrm{U}$ & D & & + & (64) \\
\hline 8 & FKBP10 & FK506-binding protein 10 & & & & + & \\
\hline 4 & FKBP9 & FK506-binding protein 9 & & D & & + & \\
\hline 43 & FLNA & Filamin-A & $\mathrm{U}$ & D & & + & (65) \\
\hline 8 & FLNB & Filamin-B & $\mathrm{U}$ & & & + & (30) \\
\hline 24 & FLNC & Filamin-C & $\mathrm{U}$ & D & & + & $(66)$ \\
\hline 23 & FN1 & Fibronectin & $\mathrm{U}$ & D & & + & (67) \\
\hline 3 & FSTL1 & Follistatin-related protein & $\mathrm{U}$ & D & & + & (68) \\
\hline 2 & FTH1 & Ferritin heavy chain & $\mathrm{U}$ & D & & + & (68) \\
\hline 2 & G6PD & Glucose-6-phosphate 1-dehydrogenase & $\mathrm{U}$ & D & & + & \\
\hline 15 & GANAB & Neutral alpha-glucosidase AB & & D & & + & (69) \\
\hline 2 & GAPDH & Glyceraldehyde-3-phosphate dehydrogenase & $\mathrm{U}$ & D & & + & (70) \\
\hline 2 & GAR1 & H/ACA ribonucleoprotein complex subunit 1 & & & + & & \\
\hline 2 & GDI1 & Rab GDP dissociation inhibitor alpha & $\mathrm{U}$ & D & & + & (71) \\
\hline 2 & GDI2 & Rab GDP dissociation inhibitor beta & $\mathrm{U}$ & D & & + & (72) \\
\hline 2 & GLRX3 & Glutaredoxin 3, Thioredoxin-like 2 & & D & & + & (73) \\
\hline 2 & GMFB & Glia maturation factor, beta & $\mathrm{U}$ & & & + & \\
\hline 5 & GPC1 & Glypican-1 & & D & + & & \\
\hline 16 & GSN & Gelsolin & $\mathrm{U}$ & D & & + & (74) \\
\hline 4 & GTF2I & General transcription factor II-I (GTF2IP4) & $\mathrm{U}$ & D & & + & \\
\hline 2 & H2AFV & Histone H2A.V, H2AZ2 & & D & + & & (75) \\
\hline 4 & H2AFY & Histone marcoH2A1, MAROH2A1 & $\mathrm{U}$ & & + & & (76) \\
\hline 2 & HARS & Histidyl-tRNA synthetase, cytoplasmic & & & & + & (19) \\
\hline 3 & HDGF & Hepatoma-derived growth factor & $\mathrm{U}$ & D & & + & (77) \\
\hline 2 & HDLBP & Vigilin, High density lipoprotein binding protein & $\mathrm{U}$ & D & & + & \\
\hline 2 & HEBP2 & Heme-binding protein 2 & $\mathrm{U}$ & & & + & \\
\hline 5 & HEXB & Beta-hexosaminidase subunit beta & & D & & + & \\
\hline 4 & HIST1H1B & Histone H1.5, H1-5 & $\mathrm{U}$ & D & & + & (78) \\
\hline 4 & HIST1H1C & Histone $\mathrm{H} 1.2, \mathrm{H} 1-2$ & $\mathrm{U}$ & D & + & & (78) \\
\hline 2 & HIST1H2BL & Histone H2B type 1-L, H2BC13 & $\mathrm{U}$ & D & + & & (79) \\
\hline 9 & HIST1H4J & Histone $\mathrm{H} 4, \mathrm{H} 4 \mathrm{C} 1$ & & & + & & (80) \\
\hline 11 & HIST2H2BE & Histone H2B type 2-E, H2BC21 & $\mathrm{U}$ & D & + & & (81) \\
\hline 3 & HIST2H3D & Histone H3.2, HIST2H3A, HIST2H3C, H3C13 & & & + & & (82) \\
\hline 4 & HMGB1L1 & High mobility group box 1 pseudogene 1, HMGB1P1 & & & & + & (83) \\
\hline 2 & HNRNPA1 & U1 ribonucleoprotein A1 & $\mathrm{U}$ & D & & + & (84) \\
\hline 5 & HNRNPA2B1 & Putative uncharacterized protein HNRNPA2B1 & $\mathrm{U}$ & $\mathrm{D}$ & & + & (85) \\
\hline 2 & HNRNPA3 & Heterogeneous nuclear ribonucleoprotein A3 & $U$ & $\mathrm{D}$ & & + & (86) \\
\hline 2 & HNRNPC & Heterogeneous nuclear ribonucleoproteins C1/C2 & $\mathrm{U}$ & D & + & & $(87)$ \\
\hline 7 & HNRNPCL1 & Heterogeneous nuclear ribonucleoprotein C-like 1 & & & & + & \\
\hline 2 & HNRNPD & Heterogeneous nuclear ribonucleoprotein D, AUF1 & & & & + & $(88)$ \\
\hline 3 & HNRNPDL & Heterogeneous nuclear ribonucleoprotein D-like & $\mathrm{U}$ & D & & + & (89) \\
\hline 5 & HNRNPF & Heterogeneous nuclear ribonucleoprotein F & & D & & + & (90) \\
\hline 2 & HNRNPH1 & Heterogeneous nuclear ribonucleoprotein $\mathrm{H} 1$ & $\mathrm{U}$ & $\mathrm{D}$ & & + & (90) \\
\hline 2 & HNRNPH3 & Heterogeneous nuclear ribonucleoprotein $\mathrm{H} 3$ & $U$ & $\mathrm{D}$ & & + & \\
\hline 9 & HNRNPK & Heterogeneous nuclear ribonucleoprotein $\mathrm{K}$ & $\mathrm{U}$ & & & + & (91) \\
\hline 7 & HNRNPR & Heterogeneous nuclear ribonucleoprotein $\mathrm{R}$ & $\mathrm{U}$ & D & & + & (92) \\
\hline 5 & HNRNPU & Heterogeneous nuclear ribonucleoprotein $U$ & $U$ & $\mathrm{D}$ & & + & \\
\hline 3 & HNRNPUL1 & HnRNP U-like protein 1 & $U$ & $\mathrm{D}$ & + & & \\
\hline 11 & HSP90AA1 & Heat shock 90kDa protein 1, alpha isoform & $\mathrm{U}$ & D & & + & (93) \\
\hline 3 & HSP90AA2 & Putative heat shock protein HSP 90-alpha A & & & & + & (94) \\
\hline 11 & HSP90AB1 & Heat shock protein HSP 90-beta & $\mathrm{U}$ & D & & + & (95) \\
\hline 31 & HSP90B1 & Endoplasmin & $U$ & $\mathrm{D}$ & & + & (96) \\
\hline 3 & HSPA1A & HSPA1B Heat shock $70 \mathrm{kDa}$ protein $1 \mathrm{~A}$ & $\mathrm{U}$ & D & & + & \\
\hline 2 & HSPA1L & Heat shock $70 \mathrm{kDa}$ protein 1-like & & & & + & (97) \\
\hline 2 & HSPA4 & Heat shock 70 kDa protein 4 & $\mathrm{U}$ & D & & + & \\
\hline 28 & HSPA5 & Endoplasmic reticulum chaperone BiP, GRP78 & $\mathrm{U}$ & D & & + & $(98)$ \\
\hline 27 & HSPA8 & Heat shock cognate $71 \mathrm{kDa}$ protein & $\mathrm{U}$ & D & & + & (99) \\
\hline 8 & HSPA9 & Stress-70 protein, mitochondrial & $\mathrm{U}$ & D & & + & (99) \\
\hline
\end{tabular}


bioRxiv preprint doi: https://doi.org/10.1101/2021.01.24.427965; this version posted January 24, 2021. The copyright holder for this preprint (which was not certified by peer review) is the author/funder, who has granted bioRxiv a license to display the preprint in perpetuity. It is made available under aCC-BY 4.0 International license.

\begin{tabular}{|c|c|c|c|c|c|c|c|}
\hline 7 & HSPB1 & Heat shock protein beta-1 & $\mathrm{U}$ & D & & + & (100) \\
\hline 2 & HSPD1 & $60 \mathrm{kDa}$ heat shock protein, mitochondrial & $\mathrm{U}$ & D & & + & \\
\hline 3 & HSPG2 & Basement membrane heparan sulfate proteoglycan & $U$ & $\mathrm{D}$ & + & & (101) \\
\hline 2 & HTATSF1 & HIV Tat-specific factor 1 & & D & + & & \\
\hline 7 & HYOU1 & Hypoxia up-regulated protein & $\mathrm{U}$ & & & + & \\
\hline 2 & IGBP1 & Immunoglobulin-binding protein 1 & $\mathrm{U}$ & D & & + & \\
\hline 7 & ILF2 & Interleukin enhancer-binding factor & $\mathrm{U}$ & & & + & (102) \\
\hline 2 & ILF3 & Interleukin enhancer-binding factor 3 & $U$ & & & + & (102) \\
\hline 13 & IQGAP1 & Ras GTPase-activating-like protein IQGAP1 & $\mathrm{U}$ & & & + & (103) \\
\hline 2 & IRGQ & Immunity-related GTPase family Q protein & $\mathrm{U}$ & D & & + & \\
\hline 4 & ITGB1 & Integrin beta-1 & $\mathrm{U}$ & D & + & & \\
\hline 4 & KARS & Lysyl-tRNA synthetase & & & & + & $(60)$ \\
\hline 2 & KPNA3 & Importin subunit alpha-4 & & & + & & \\
\hline 8 & KPNB1 & Importin subunit beta-1 & & & + & & (104) \\
\hline 10 & KTN1 & Kinectin & $\mathrm{U}$ & & & + & (105) \\
\hline 7 & LAMB1 & Laminin subunit beta-1 & & D & & + & (106) \\
\hline 5 & LAMC1 & Laminin subunit gamma-1 & $\mathrm{U}$ & D & & + & (107) \\
\hline 3 & LCP1 & Plastin-2 & $\mathrm{U}$ & D & & + & (108) \\
\hline 5 & LGALS1 & Galectin-1 & $\mathrm{U}$ & D & & + & (109) \\
\hline 23 & LMNA & Isoform $A$ of Lamin-A/C & $\mathrm{U}$ & D & & + & (110) \\
\hline 3 & LMNB1 & Lamin-B1 & $\mathrm{U}$ & D & & + & (111) \\
\hline 7 & LMNB2 & Lamin-B2 & $\mathrm{U}$ & D & + & & (112) \\
\hline 2 & LRPPRC & Leucine-rich PPR motif-containing protein & & D & & + & (113) \\
\hline 2 & LSM2 & U6 snRNA-associated Sm-like protein LSm2 & $\mathrm{U}$ & & & + & \\
\hline 2 & LSM6 & U6 snRNA-associated Sm-like protein LSm6 & $\mathrm{U}$ & & & + & \\
\hline 2 & MAGOHB & Protein mago nashi homolog & $\mathrm{U}$ & D & & + & \\
\hline 3 & MANBA & Beta-mannosidase & & D & & + & \\
\hline 3 & MAP1B & Microtubule-associated protein 1B & $\mathrm{U}$ & D & & + & (114) \\
\hline 6 & MAPRE1 & Microtubule-associated protein RP/EB family member & & & & + & \\
\hline 10 & MOV10 & Putative helicase, Moloney leukemia virus 10 protein & $\mathrm{U}$ & D & + & & \\
\hline 3 & MSN & Moesin & $\mathrm{U}$ & & & + & (115) \\
\hline 21 & MVP & Major vault protein & $\mathrm{U}$ & D & + & & (116) \\
\hline 4 & MXRA5 & Matrix-remodeling-associated protein 5 & & D & + & & (116) \\
\hline 2 & MYH10 & Myosin-10 & $\mathrm{U}$ & D & + & & (117) \\
\hline 43 & MYH9 & Myosin-9 & $\mathrm{U}$ & D & + & & (117) \\
\hline 3 & MYL6 & Myosin light chain 6 & $\mathrm{U}$ & & & + & \\
\hline 4 & MYLK & Myosin light chain kinase, smooth muscle & $\mathrm{U}$ & D & & + & \\
\hline 3 & MYO1C & Unconventional myosin-Ic & & D & + & & (118) \\
\hline 2 & NACA & Nascent polypeptide associated complex subunit alpha & $\mathrm{U}$ & D & & + & (119) \\
\hline 3 & NAP1L1 & Nucleosome assembly protein 1-like 1 & $\mathrm{U}$ & $\mathrm{D}$ & + & & \\
\hline 3 & NAP1L4 & Nucleosome assembly protein 1-like 4 & $\mathrm{U}$ & D & + & & \\
\hline 2 & NASP & Nuclear autoantigenic sperm protein & $\mathrm{U}$ & D & & + & (120) \\
\hline 11 & $\mathrm{NCL}$ & Nucleolin & $\mathrm{U}$ & D & + & & (121) \\
\hline 2 & NES & Nestin & $\mathrm{U}$ & D & & + & \\
\hline 2 & NEU1 & Sialidase-1 & $\mathrm{U}$ & D & & + & (122) \\
\hline 3 & NEXN & Nexilin F-actin binding protein & $\mathrm{U}$ & D & & + & \\
\hline 2 & NFU1 & HIRA interacting protein 5 & & & & + & \\
\hline 3 & NME1 & Nucleoside diphosphate kinase A, RMRP & $\mathrm{U}$ & D & & + & $(123)$ \\
\hline 2 & NMT1 & Glycylpeptide N-tetradecanoyltransferase 1 & & & & + & (124) \\
\hline 2 & NMT2 & Glycylpeptide N-tetradecanoyltransferase 2 & & D & & + & \\
\hline 4 & NPEPPS & Puromycin-sensitive aminopeptidase & & & & + & \\
\hline 7 & NPM1 & Nucleophosmin & $\mathrm{U}$ & D & & + & (125) \\
\hline 5 & NUDC & Nuclear distribution C, Dynein complex regulator & & $\mathrm{D}$ & & + & \\
\hline 3 & NUDT21 & Cleavage and polyadenylation specificity factor 5 & & D & & + & \\
\hline 2 & NUDT5 & Nudix hydrolase 5 & & D & & + & \\
\hline 3 & NUMA1 & Nuclear mitotic apparatus protein 1 & $\mathrm{U}$ & D & & + & (126) \\
\hline 5 & P3H1 & Basement membrane chondroitin sulfate proteoglycan & $\mathrm{U}$ & & & + & \\
\hline 2 & $\mathrm{P} 3 \mathrm{H} 3$ & Prolyl 3-hydroxylase 3, LEPREL2 & & D & + & & \\
\hline 2 & P3H4 & ER protein SC65, nucleolar autoantigen No55 & & & + & & $(127)$ \\
\hline 2 & P4HA2 & Prolyl 4-hydroxylase subunit alpha-2 & & D & & + & \\
\hline 18 & $\mathrm{P} 4 \mathrm{HB}$ & Protein disulfide-isomerase & $\mathrm{U}$ & D & & + & (128) \\
\hline 4 & PA2G4 & Proliferation-associated protein 2G4 & $\mathrm{U}$ & D & & + & \\
\hline 19 & PABPC1 & Poly(A)-binding protein 1 & & D & + & & (129) \\
\hline 7 & PABPC4 & Poly(A)-binding protein 4, APP1 & & D & + & & $(130)$ \\
\hline 3 & PARVA & Alpha-parvin & $\mathrm{U}$ & & & + & \\
\hline 4 & PCNA & Proliferating cell nuclear antigen & $\mathrm{U}$ & D & & + & (131) \\
\hline
\end{tabular}


bioRxiv preprint doi: https://doi.org/10.1101/2021.01.24.427965; this version posted January 24, 2021. The copyright holder for this preprint (which was not certified by peer review) is the author/funder, who has granted bioRxiv a license to display the preprint in perpetuity. It is made available under aCC-BY 4.0 International license.

\begin{tabular}{|c|c|c|c|c|c|c|c|}
\hline 17 & PDIA3 & Protein disulfide-isomerase $\mathrm{A} 3$ & $U$ & $\mathrm{D}$ & & + & (132) \\
\hline 34 & PDIA4 & Protein disulfide-isomerase A4 & $\mathrm{U}$ & $\mathrm{D}$ & & + & \\
\hline 9 & PDIA6 & Protein disulfide-isomerase $A 6$ & $U$ & $\mathrm{D}$ & & + & \\
\hline 3 & PFDN2 & Prefoldin subunit 2 & $U$ & & & + & (133) \\
\hline 8 & PFN1 & Profilin-1 & $\mathrm{U}$ & D & & + & (134) \\
\hline 2 & PFN2 & Profilin-2 & $\mathrm{U}$ & & & + & (135) \\
\hline 91 & PLEC & Plectin-1, PLEC1 & $U$ & $\mathrm{D}$ & & + & (136) \\
\hline 5 & PLOD1 & Procollagen-lysine, 2-oxoglutarate 5-dioxygenase 1 & & $\mathrm{D}$ & & + & \\
\hline 5 & PLOD3 & $\begin{array}{l}\text { Multifunctional procollagen lysine hydroxylase and } \\
\text { glycosyltransferase LH3 }\end{array}$ & & & & + & \\
\hline 6 & PLS3 & Plastin-3 & U & D & & + & \\
\hline 10 & PPIB & Peptidyl-prolyl cis-trans isomerase & $U$ & $\mathrm{D}$ & & + & (137) \\
\hline 4 & PRDX3 & Thioredoxin-dependent peroxide reductase & $U$ & $\mathrm{D}$ & & + & (138) \\
\hline 3 & PRDX4 & Peroxiredoxin-4 & $U$ & $\mathrm{D}$ & & + & (139) \\
\hline 2 & PRKAR2A & Protein kinase CAMP-dependent type II regulatory alpha & $U$ & & & + & \\
\hline 2 & PRKCDBP & Protein kinase $\mathrm{C}$ delta-binding protein & & & & + & \\
\hline 11 & PRKCSH & Protein kinase $\mathrm{C}$ substrate $80 \mathrm{~K}-\mathrm{H}$ & & $\mathrm{D}$ & & + & \\
\hline 5 & PRKDC & DNA-dependent protein kinase catalytic subunit & $\mathrm{U}$ & $\mathrm{D}$ & + & & (140) \\
\hline 4 & PRMT1 & Protein arginine N-methyltransferase 1 & & $\mathrm{D}$ & & + & \\
\hline 24 & PRPF8 & Pre-mRNA-processing-splicing factor 8 & $\mathrm{U}$ & $\mathrm{D}$ & + & & (30) \\
\hline 2 & PSAP & Proactivator polypeptide, Prosaposin & $U$ & $\mathrm{D}$ & & + & \\
\hline 5 & PSMA3 & Proteasome subunit alpha type-3, C8 & $\mathrm{U}$ & $\mathrm{D}$ & & + & (141) \\
\hline 4 & PSMA4 & Proteasome subunit alpha type-4, C9 & $\mathrm{U}$ & & & + & (142) \\
\hline 4 & PSMA5 & Proteasome subunit alpha type-5 & $U$ & & & + & (143) \\
\hline 6 & PSMA6 & Proteasome subunit alpha type- 6 & $u$ & D & & + & \\
\hline 6 & PSMA7 & Proteasome subunit alpha type-7 & $U$ & $\mathrm{D}$ & & + & (144) \\
\hline 5 & PSMB1 & Proteasome subunit beta type-1 & & & & + & (145) \\
\hline 2 & PSMB3 & Proteasome subunit beta type-3 & & D & & + & (141) \\
\hline 7 & PSMB4 & Proteasome subunit beta type- 4 & & & & + & \\
\hline 3 & PSMB6 & Proteasome subunit beta type- 6 & & $\mathrm{D}$ & & + & \\
\hline 5 & PSMB7 & Proteasome subunit beta type- 7 & & $\mathrm{D}$ & & + & \\
\hline 2 & PSMD1 & 26S proteasome non-ATPase regulatory subunit 1 & $\mathrm{U}$ & & + & & \\
\hline 2 & PSMD12 & 26S proteasome non-ATPase regulatory subunit 12 & & $\mathrm{D}$ & + & & \\
\hline 3 & PSMD13 & Proteasome $26 \mathrm{~S}$ non-ATPase subunit 13 & & $\mathrm{D}$ & & + & (146) \\
\hline 9 & PSMD6 & 26S proteasome non-ATPase regulatory subunit 6 & & & & + & \\
\hline 2 & PSMD7 & 26S proteasome non-ATPase regulatory subunit 7 & U & & & + & \\
\hline 6 & PTBP1 & Polypyrimidine tract-binding protein, hnRNP I & $U$ & D & & + & $(147)$ \\
\hline 2 & PTCD3 & Pentatricopeptide repeat domain 3, MRPS39 & & & + & & \\
\hline 2 & PUF60 & Poly(U)-binding-splicing factor PUF60 & $U$ & & & + & (148) \\
\hline 2 & PZP & Pregnancy zone protein, alpha-2-macroglobulin like & & D & & + & (149) \\
\hline 4 & QARS & Glutaminyl-tRNA synthetase & & & + & & $(60)$ \\
\hline 3 & RAB1A & Ras-related protein Rab-1A & & $\mathrm{D}$ & + & & \\
\hline 3 & RAB7A & Ras-related protein Rab-7a & $\mathrm{U}$ & $\mathrm{D}$ & & + & \\
\hline 3 & RAD23A & UV excision repair protein RAD23 homolog A & & $\mathrm{D}$ & & + & (150) \\
\hline 5 & RAD23B & UV excision repair protein RAD23 homolog B & $U$ & $\mathrm{D}$ & & + & $(150)$ \\
\hline 6 & RALY & RNA binding protein, autoantigen p542 & $U$ & $\mathrm{D}$ & + & & (151) \\
\hline 5 & RBBP4 & Chromosome assembly factor 1 subunit $\mathrm{C}$ & & $\mathrm{D}$ & + & & (152) \\
\hline 2 & RBM3 & Putative RNA-binding protein 3 & $U$ & $\mathrm{D}$ & & + & \\
\hline 2 & RBMXL2 & RNA-binding motif protein X-linked-like-2 & & & & + & \\
\hline 2 & RCN3 & Reticulocalbin-3 & & & & + & \\
\hline 2 & RDX & Radixin & & & & + & (153) \\
\hline 2 & ROD1 & Regulator of differentiation 1, PTBP3 & $U$ & D & & + & (147) \\
\hline 2 & RPF2 & Ribosome production factor 2 homolog, BXDC1 & & & + & & \\
\hline 2 & RPL11 & 60S ribosomal protein L11 & $\mathrm{U}$ & & + & & \\
\hline 2 & RPL12 & $60 S$ ribosomal protein L12 & $U$ & D & + & & (154) \\
\hline 2 & RPL15 & 60S ribosomal protein L15 & & D & + & & \\
\hline 3 & RPL18 & 60 S ribosomal protein L18 & & $\mathrm{D}$ & + & & \\
\hline 2 & RPL22 & 60S ribosomal protein L22 & & D & & + & \\
\hline 16 & RPL5 & 60S ribosomal protein L5 & & D & + & & (155) \\
\hline 8 & RPL6 & $60 S$ ribosomal protein $\mathrm{L} 6$ & $\mathrm{U}$ & $\mathrm{D}$ & + & & (135) \\
\hline 8 & RPL7 & $60 S$ ribosomal protein $\mathrm{L7}$ & $U$ & $\mathrm{D}$ & + & & (156) \\
\hline 7 & RPLPO & $60 \mathrm{~S}$ acidic ribosomal protein $\mathrm{P} 0$ & $U$ & $\mathrm{D}$ & + & & (157) \\
\hline 4 & RPLP2 & $60 \mathrm{~S}$ acidic ribosomal protein $\mathrm{P} 2$ & $U$ & $\mathrm{D}$ & + & & \\
\hline 3 & RPS18 & 40S ribosomal protein S18 & $U$ & $\mathrm{D}$ & + & & (158) \\
\hline 3 & RPS19 & 40S ribosomal protein S19 & & $\mathrm{D}$ & & + & (159) \\
\hline 3 & RPS2 & 40S ribosomal protein S2 & U & D & + & & \\
\hline
\end{tabular}


bioRxiv preprint doi: https://doi.org/10.1101/2021.01.24.427965; this version posted January 24, 2021. The copyright holder for this preprint (which was not certified by peer review) is the author/funder, who has granted bioRxiv a license to display the preprint in perpetuity. It is made available under aCC-BY 4.0 International license.

\begin{tabular}{|c|c|c|c|c|c|c|c|}
\hline 4 & RPS3 & 40S ribosomal protein S3 & $\mathrm{U}$ & $\mathrm{D}$ & & + & (160) \\
\hline 2 & RPS3A & $40 \mathrm{~S}$ ribosomal protein S3a & $\mathrm{U}$ & D & & + & \\
\hline 3 & RPS4X & $40 \mathrm{~S}$ ribosomal protein $\mathrm{S} 4, \mathrm{X}$ isoform & & D & + & & \\
\hline 2 & RPS8 & 40S ribosomal protein S8 & $\mathrm{U}$ & D & + & & \\
\hline 7 & RPS9 & $40 \mathrm{~S}$ ribosomal protein S9 & & D & + & & (159) \\
\hline 13 & RRBP1 & Ribosome-binding protein 1 & $\mathrm{U}$ & D & & + & \\
\hline 2 & SAE1 & SUMO-activating enzyme subunit 1 & $\mathrm{U}$ & D & & + & (161) \\
\hline 4 & SEPHS1 & Selenide, water dikinase & & D & & + & (162) \\
\hline 2 & SEPT2 & Septin-2, NEDD5, DIFF6 & $\mathrm{U}$ & & & + & (163) \\
\hline 3 & SERPINE1 & Plasminogen activator inhibitor 1 & $\mathrm{U}$ & D & & + & (164) \\
\hline 4 & SERPINH1 & Serpin H1, HSP47 & & D & & + & (165) \\
\hline 6 & SET & SET nuclear proto-oncogene & $\mathrm{U}$ & D & + & & \\
\hline 6 & SF3B1 & Splicing factor 3B subunit 1 & $\mathrm{U}$ & D & + & & (166) \\
\hline 7 & SF3B3 & Splicing factor 3B subunit 3 & & & + & & (166) \\
\hline 3 & SFPQ & Splicing factor, proline- and glutamine-rich & $\mathrm{U}$ & D & & + & (167) \\
\hline 2 & SFRS11 & Splicing factor, arginine/serine-rich 11, SRSF11 & $\mathrm{U}$ & D & & + & \\
\hline 3 & SFRS2 & Splicing factor, arginine/serine-rich 2, SRSF2 & $\mathrm{U}$ & D & & + & (38) \\
\hline 2 & SFRS7 & Serine /arginine-rich splicing factor 7, SRSF7 & $\mathrm{U}$ & & + & & (168) \\
\hline 3 & SH3BGRL3 & $\begin{array}{l}\text { Putative uncharacterized protein, SH3 domain-binding } \\
\text { glutamic acid-rich-like protein } 3\end{array}$ & & D & & + & \\
\hline 2 & SKP1 & S-phase kinase-associated protein 1 & $\mathrm{U}$ & D & & + & \\
\hline 2 & SLC3A2 & 4F2 cell-surface antigen heavy chain, CD98 & $\mathrm{U}$ & D & + & & \\
\hline 4 & SMS & Spermine synthase & $\mathrm{U}$ & D & & + & \\
\hline 9 & SND1 & Staphylococcal nuclease domain-containing protein 1 & $\mathrm{U}$ & D & & + & \\
\hline 2 & SNRNP200 & U5 small nuclear ribonucleoprotein 200 kDa helicase & & D & + & & \\
\hline 3 & SNRPA & U1 small nuclear ribonucleoprotein A & $\mathrm{U}$ & & & + & (169) \\
\hline 2 & SNRPB & SnRNP-associated proteins B and B' & $\mathrm{U}$ & D & + & & $(170)$ \\
\hline 2 & SNRPD1 & Small nuclear ribonucleoprotein Sm D1 & $\mathrm{U}$ & & + & & (171) \\
\hline 2 & SNRPD2 & Small nuclear ribonucleoprotein Sm D2 & & D & + & & (172) \\
\hline 2 & SNRPD3 & Small nuclear ribonucleoprotein Sm D3 & & D & + & & (171) \\
\hline 2 & SNRPE & Small nuclear ribonucleoprotein E & & D & + & & (173) \\
\hline 37 & SPTAN1 & Highly similar to Spectrin alpha chain, brain & $\mathrm{U}$ & D & & + & (174) \\
\hline 19 & SPTBN1 & Spectrin beta chain, brain & $\mathrm{U}$ & D & + & & (175) \\
\hline 11 & SSB & Lupus La protein & $\mathrm{U}$ & & & + & (19) \\
\hline 6 & SSBP1 & Single-stranded DNA-binding protein, mitochondrial & & & + & & \\
\hline 4 & SSRP1 & FACT complex subunit SSRP1 & $\mathrm{U}$ & D & + & & (176) \\
\hline 3 & ST13 & Hsc70-interacting protein & $\mathrm{U}$ & & & + & (177) \\
\hline 2 & STRBP & Spermatid perinuclear RNA-binding protein & & & & + & \\
\hline 3 & SUB1 & Activated RNA polymerase II transcriptional coactivator p15 & $\mathrm{U}$ & D & & + & \\
\hline 2 & SUMO1 & Small ubiquitin-related modifier & & D & & + & (161) \\
\hline 4 & SUPT16H & FACT complex subunit SPT16 & & D & + & & \\
\hline 3 & SYNCRIP & Heterogeneous nuclear ribonucleoprotein Q & & D & & + & \\
\hline 3 & TFG & Trafficking from ER to Golgi regulator & & & & + & \\
\hline 9 & THBS1 & Thrombospondin-1 & $\mathrm{U}$ & D & & + & (178) \\
\hline 29 & TLN1 & Talin-1 & $\mathrm{U}$ & $\mathrm{D}$ & & + & (179) \\
\hline 4 & TLN2 & Talin-2 & $\mathrm{U}$ & & & + & \\
\hline 6 & TNC & Tenascin C & & D & & + & (180) \\
\hline 3 & TPD52L2 & Tumor protein D54 & $\mathrm{U}$ & D & & + & \\
\hline 16 & TPM1 & Tropomyosin 1 alpha chain & $\mathrm{U}$ & D & & + & (181) \\
\hline 17 & TPM2 & Tropomyosin beta chain & $\mathrm{U}$ & D & & + & \\
\hline 6 & TPM3 & Tropomyosin alpha-3 chain & $\mathrm{U}$ & D & & + & (182) \\
\hline 20 & TPM4 & Tropomyosin alpha-4 chain & $\mathrm{U}$ & D & & + & (183) \\
\hline 2 & TPP1 & Tripeptidyl-peptidase 1 & $\mathrm{U}$ & D & + & & \\
\hline 4 & TPR & Nucleoprotein TPR & $\mathrm{U}$ & D & & + & (184) \\
\hline 4 & TPT1 & Tumor protein, translationally-controlled & $U$ & $\mathrm{D}$ & & + & \\
\hline 2 & TROVE2 & 60 kDa SS-A/Ro ribonucleoprotein & $\mathrm{U}$ & & + & & \\
\hline 4 & TUBA1C & Tubulin alpha-1C chain & $U$ & $\mathrm{D}$ & + & & (185) \\
\hline 6 & TUBA4A & Tubulin alpha-4A chain, TUBA1 & $U$ & $\mathrm{D}$ & + & & (186) \\
\hline 3 & TUBB & Tubulin beta chain & $\mathrm{U}$ & D & + & & (187) \\
\hline 2 & TUBB1 & Tubulin beta-1 chain & & & + & & (186) \\
\hline 3 & TUBB4B & Tubulin beta-2C, tubulin beta-4B, TUBB2C & $\mathrm{U}$ & $\mathrm{D}$ & + & & (188) \\
\hline 2 & TXN & Thioredoxin & $U$ & D & & + & (189) \\
\hline 2 & TXNDC17 & Thioredoxin domain-containing protein 17 & $\mathrm{U}$ & D & & + & \\
\hline 4 & TXNDC5 & Thioredoxin domain-containing protein 5 & $\mathrm{U}$ & D & & + & \\
\hline 2 & TXNRD1 & Thioredoxin reductase 1 , cytoplasmic & $\mathrm{U}$ & D & & + & (189) \\
\hline 8 & UBA1 & Ubiquitin-like modifier-activating enzyme 1 & $\mathrm{U}$ & & & + & (190) \\
\hline
\end{tabular}




\begin{tabular}{|c|c|c|c|c|c|c|c|}
\hline 2 & UCHL1 & Ubiquitin carboxyl-terminal hydrolase isozyme L1 & $\mathrm{U}$ & $\mathrm{D}$ & & + & (191) \\
\hline 6 & UGCGL1 & UDP-glucose:glycoprotein glucosyltransferase 1 & & $\mathrm{D}$ & & + & \\
\hline 18 & UPF1 & Regulator of nonsense transcripts 1 & & $\mathrm{D}$ & + & & \\
\hline 3 & USP5 & Ubiquitin carboxyl-terminal hydrolase 5 & $\mathrm{U}$ & D & & + & \\
\hline 2 & USP9X & Ubiquitin specific protease $9, \mathrm{X}$ chromosome & $\mathrm{U}$ & $\mathrm{D}$ & + & & \\
\hline 4 & VASN & Vasorin & $\mathrm{U}$ & $\mathrm{D}$ & & + & \\
\hline 4 & VAT1 & Synaptic vesicle membrane protein VAT-1 homolog & $\mathrm{U}$ & D & & + & \\
\hline 3 & VBP1 & Von Hippel-Lindau binding protein & & D & & + & \\
\hline 13 & VCL & Vinculin & U & $\mathrm{D}$ & & + & (192) \\
\hline 15 & VCP & Transitional endoplasmic reticulum ATPase & $\mathrm{U}$ & D & & + & (193) \\
\hline 17 & VIM & Vimentin & $\mathrm{U}$ & D & + & & (194) \\
\hline 5 & WARS & Tryptophanyl-tRNA synthetase, cytoplasmic & $U$ & $\mathrm{D}$ & & + & (195) \\
\hline 21 & XRCC5 & ATP-dependent DNA helicase 2 subunit 2, Ku80 & & $\mathrm{D}$ & + & & (196) \\
\hline 21 & XRCC6 & ATP-dependent DNA helicase 2 subunit 1, Ku70 & $\mathrm{U}$ & $\mathrm{D}$ & + & & (197) \\
\hline 5 & YBX3 & D-binding protein A, CSDA, DBPA & $\mathrm{U}$ & $\mathrm{D}$ & + & & (198) \\
\hline 5 & YWHAB & 14-3-3 protein beta/alpha & $\mathrm{U}$ & D & & + & \\
\hline 9 & YWHAE & 14-3-3 protein epsilon & $\mathrm{U}$ & D & & + & (199) \\
\hline 3 & YWHAG & 14-3-3 protein gamma & U & D & & + & (199) \\
\hline 3 & YWHAH & 14-3-3 protein eta & & $\mathrm{D}$ & & + & (200) \\
\hline 5 & YWHAQ & 14-3-3 protein theta & $U$ & $\mathrm{D}$ & & + & $(201)$ \\
\hline 5 & YWHAZ & 14-3-3 protein zeta/delta & $\mathrm{U}$ & $\mathrm{D}$ & & + & $(202)$ \\
\hline
\end{tabular}

Notes: \# Pep., number of peptides identified by mass spectrometry; COVID (Up/Down), protein or gene expression up- and/or downregulated in SARS-Cov-2 infected cells or patients; DS affinity, concentration of $\mathrm{NaCl}(1.0 \mathrm{M}$, very high affinity, or $0.5 \mathrm{M}$, medium to high affinity) at which a DS-binding protein elutes from DS-affinity resin.

\section{References for Table 1}

1. R. D. Saunders, S. T. Nakajima, S. N. Rai, J. Pan, C. Gercel-Taylor, D. D. Taylor, Alterations in antibody subclass immune reactivity to trophoblast-derived fetal fibronectin and $\alpha 2$-macroglobulin in women with recurrent pregnancy loss. Am J Reprod Immunol 68, 438-449 (2012).

2. C. C. Bunn, R. M. Bernstein, M. B. Mathews, Autoantibodies against alanyl-tRNA synthetase and tRNAAla coexist and are associated with myositis. The Journal of experimental medicine $163,1281-$ 1291 (1986).

3. P. V. Mande, F. R. Parikh, I. Hinduja, K. Zaveri, R. Vaidya, R. Gajbhiye, V. V. Khole, Identification and validation of candidate biomarkers involved in human ovarian autoimmunity. Reprod Biomed Online 23, 471-483 (2011).

4. J. J. van Beers, C. M. Schwarte, J. Stammen-Vogelzangs, E. Oosterink, B. Bozic, G. J. Pruijn, The rheumatoid arthritis synovial fluid citrullinome reveals novel citrullinated epitopes in apolipoprotein E, myeloid nuclear differentiation antigen, and beta-actin. Arthritis and rheumatism 65, 69-80 (2013).

5. C. Hanrotel-Saliou, I. Segalen, Y. Le Meur, P. Youinou, Y. Renaudineau, Glomerular antibodies in lupus nephritis. Clin Rev Allergy Immunol 40, 151-158 (2011).

6. T. Wang, M. Liu, S. J. Zheng, D. D. Bian, J. Y. Zhang, J. Yao, Q. F. Zheng, A. M. Shi, W. H. Li, L. Li, Y. Chen, J. H. Wang, Z. P. Duan, L. Dong, Tumor-associated autoantibodies are useful biomarkers in immunodiagnosis of $\alpha$-fetoprotein-negative hepatocellular carcinoma. World J Gastroenterol 23, 3496-3504 (2017).

7. F. Sköldberg, L. Rönnblom, M. Thornemo, A. Lindahl, P. I. Bird, F. Rorsman, O. Kämpe, E. Landgren, Identification of AHNAK as a novel autoantigen in systemic lupus erythematosus. Biochemical and biophysical research communications 291, 951-958 (2002).

8. J. Nehring, L. A. Schirmbeck, J. Friebus-Kardash, D. Dubler, U. Huynh-Do, C. Chizzolini, C. Ribi, M. Trendelenburg, Autoantibodies Against Albumin in Patients With Systemic Lupus Erythematosus. Frontiers in immunology 9, 2090 (2018). 
9. D. Lu, E. Kuhn, R. E. Bristow, R. L. Giuntoli, 2nd, S. K. Kjær, M. Shih le, R. B. Roden, Comparison of candidate serologic markers for type I and type II ovarian cancer. Gynecol Oncol 122, 560-566 (2011).

10. D. J. Caster, E. A. Korte, M. L. Merchant, J. B. Klein, D. W. Wilkey, B. H. Rovin, D. J. Birmingham, J. B. Harley, B. L. Cobb, B. Namjou, K. R. McLeish, D. W. Powell, Autoantibodies targeting glomerular annexin A2 identify patients with proliferative lupus nephritis. Proteomics Clin Appl 9, 1012-1020 (2015).

11. A. Hrycek, P. Cieślik, Annexin A5 and anti-annexin antibodies in patients with systemic lupus erythematosus. Rheumatol Int 32, 1335-1342 (2012).

12. Y. Seko, A. Matsumoto, T. Fukuda, Y. Imai, T. Fujimura, H. Taka, R. Mineki, K. Murayama, Y. Hirata, R. Nagai, A case of neonatal lupus erythematosus presenting delayed dilated cardiomyopathy with circulating autoantibody to annexin A6. Int Heart J 48, 407-415 (2007).

13. S. Jarius, B. Wildemann, 'Medusa head ataxia': the expanding spectrum of Purkinje cell antibodies in autoimmune cerebellar ataxia. Part 3: Anti-Yo/CDR2, anti-Nb/AP3B2, PCA-2, anti-Tr/DNER, other antibodies, diagnostic pitfalls, summary and outlook. Journal of neuroinflammation 12, 168 (2015).

14. N. Vuilleumier, F. Montecucco, O. Hartley, Autoantibodies to apolipoprotein A-1 as a biomarker of cardiovascular autoimmunity. World J Cardio/ 6, 314-326 (2014).

15. J. Creaney, I. M. Dick, D. Yeoman, S. Wong, B. W. Robinson, Auto-antibodies to $\beta$-F1-ATPase and vimentin in malignant mesothelioma. PloS one 6, e26515 (2011).

16. A. Polgár, A. Falus, E. Koó, I. Ujfalussy, M. Seszták, I. Szuts, K. Konrád, L. Hodinka, E. Bene, G. Mészáros, Z. Ortutay, E. Farkas, A. Paksy, E. I. Buzás, Elevated levels of synovial fluid antibodies reactive with the small proteoglycans biglycan and decorin in patients with rheumatoid arthritis or other joint diseases. Rheumatology (Oxford, England) 42, 522-527 (2003).

17. N. M. Bhat, C. M. Adams, Y. Chen, M. M. Bieber, N. N. Teng, Identification of Cell Surface Straight Chain Poly-N-Acetyl-Lactosamine Bearing Protein Ligands for VH4-34-Encoded Natural IgM Antibodies. Journal of immunology (Baltimore, Md. : 1950) 195, 5178-5188 (2015).

18. V. M. Beutgen, C. Schmelter, N. Pfeiffer, F. H. Grus, Autoantigens in the trabecular meshwork and glaucoma-specific alterations in the natural autoantibody repertoire. Clin Transl Immunology 9, e01101 (2020).

19. C. N. Gruber, R. S. Patel, R. Trachtman, L. Lepow, F. Amanat, F. Krammer, K. M. Wilson, K. Onel, D. Geanon, K. Tuballes, M. Patel, K. Mouskas, T. O'Donnell, E. Merritt, N. W. Simons, V. Barcessat, D. M. Del Valle, S. Udondem, G. Kang, S. Gangadharan, G. Ofori-Amanfo, U. Laserson, A. Rahman, S. Kim-Schulze, A. W. Charney, S. Gnjatic, B. D. Gelb, M. Merad, D. Bogunovic, Mapping Systemic Inflammation and Antibody Responses in Multisystem Inflammatory Syndrome in Children (MIS-C). Cell 183, 982-995.e914 (2020).

20. U. Kishore, R. D. Sontheimer, K. N. Sastry, E. G. Zappi, G. R. Hughes, M. A. Khamashta, K. B. Reid, P. Eggleton, The systemic lupus erythematosus (SLE) disease autoantigen-calreticulin can inhibit C1q association with immune complexes. Clinical and experimental immunology 108, 181-190 (1997).

21. B. Terrier, M. C. Tamby, L. Camoin, P. Guilpain, C. Broussard, G. Bussone, A. Yaïci, F. Hotellier, G. Simonneau, L. Guillevin, M. Humbert, L. Mouthon, Identification of target antigens of antifibroblast antibodies in pulmonary arterial hypertension. American journal of respiratory and critical care medicine 177, 1128-1134 (2008).

22. C. K. Weber, M. Haslbeck, M. Englbrecht, B. Sehnert, D. Mielenz, D. Graef, J. H. Distler, R. B. Mueller, H. Burkhardt, G. Schett, R. E. Voll, B. G. Furnrohr, Antibodies to the endoplasmic reticulum-resident chaperones calnexin, BiP and Grp94 in patients with rheumatoid arthritis and systemic lupus erythematosus. Rheumatology (Oxford, England) 49, 2255-2263 (2010).

23. K. Matsuo, Y. Xiang, H. Nakamura, K. Masuko, K. Yudoh, K. Noyori, K. Nishioka, T. Saito, T. Kato, Identification of novel citrullinated autoantigens of synovium in rheumatoid arthritis using a proteomic approach. Arthritis research \& therapy 8, R175 (2006). 
24. W. H. Li, J. Zhao, H. Y. Li, H. Liu, A. L. Li, H. X. Wang, J. Wang, K. He, B. Liang, M. Yu, B. F. Shen, X. M. Zhang, Proteomics-based identification of autoantibodies in the sera of healthy Chinese individuals from Beijing. Proteomics 6, 4781-4789 (2006).

25. K. Furuta, B. Hildebrandt, S. Matsuoka, K. Kiyosawa, G. Reimer, C. Luderschmidt, E. K. Chan, E. M. Tan, Immunological characterization of heterochromatin protein p25beta autoantibodies and relationship with centromere autoantibodies and pulmonary fibrosis in systemic scleroderma. $\mathrm{J} \mathrm{Mol}$ Med (Berl) 76, 54-60 (1998).

26. K. Ohyama, M. Baba, M. Tamai, N. Aibara, K. Ichinose, N. Kishikawa, A. Kawakami, N. Kuroda, Proteomic profiling of antigens in circulating immune complexes associated with each of seven autoimmune diseases. Clin Biochem 48, 181-185 (2015).

27. K. Hirai, H. Maeda, K. Omori, T. Yamamoto, S. Kokeguchi, S. Takashiba, Serum antibody response to group II chaperonin from Methanobrevibacter oralis and human chaperonin CCT. Pathog Dis 68, 1219 (2013).

28. M. Ebrahimi, E. Nylander, B. Bäcklund, Y. B. Wahlin, P. J. Coates, K. Nylander, The use of a novel ELISA method for detection of antibodies against p63 in sera from patients diagnosed with oral and/or genital and skin lichen planus. Journal of oral pathology \& medicine : official publication of the International Association of Oral Pathologists and the American Academy of Oral Pathology 39, 486-490 (2010).

29. L. Zhu, W. Shen, M. Zhu, N. J. Coorey, A. P. Nguyen, D. Barthelmes, M. C. Gillies, Anti-retinal antibodies in patients with macular telangiectasia type 2. Invest Ophthalmol Vis Sci 54, 5675-5683 (2013).

30. J. H. Rho, W. Zhang, M. Murali, M. H. Roehrl, J. Y. Wang, Human proteins with affinity for dermatan sulfate have the propensity to become autoantigens. Am J Pathol 178, 2177-2190 (2011).

31. M. K. Koivula, S. Aman, A. Karjalainen, M. Hakala, J. Risteli, Are there autoantibodies reacting against citrullinated peptides derived from type I and type II collagens in patients with rheumatoid arthritis? Annals of the rheumatic diseases 64, 1443-1450 (2005).

32. J. Pardos-Gea, J. Cortés-Hernández, J. Castro-Marrero, E. Balada, J. Ordi-Ros, Autoantibodies to types I and IV collagen and heart valve disease in systemic lupus erythematosus/antiphospholipid syndrome. Clinical rheumatology 36, 1401-1406 (2017).

33. G. R. Araujo, J. E. Fonseca, P. T. Fujimura, J. P. Cunha-Junior, C. H. Silva, A. F. Mourão, H. Canhão, L. R. Goulart, J. Gonçalves, C. Ueira-Vieira, Anti-type II collagen antibodies detection and avidity in patients with oligoarticular and polyarticular forms of juvenile idiopathic arthritis. Immunology letters 165, 20-25 (2015).

34. G. Nakos, A. Adams, N. Andriopoulos, Antibodies to collagen in patients with idiopathic pulmonary fibrosis. Chest 103, 1051-1058 (1993).

35. R. R. Hachem, V. Tiriveedhi, G. A. Patterson, A. Aloush, E. P. Trulock, T. Mohanakumar, Antibodies to $\mathrm{K}-\alpha 1$ tubulin and collagen $\mathrm{V}$ are associated with chronic rejection after lung transplantation. American journal of transplantation : official journal of the American Society of Transplantation and the American Society of Transplant Surgeons 12, 2164-2171 (2012).

36. D. S. Nath, H. I. Basha, T. Mohanakumar, Antihuman leukocyte antigen antibody-induced autoimmunity: role in chronic rejection. Current opinion in organ transplantation 15, 16-20 (2010).

37. T. J. Vece, L. B. Watkin, S. Nicholas, D. Canter, M. C. Braun, R. P. Guillerman, K. W. Eldin, G. Bertolet, S. McKinley, M. de Guzman, L. Forbes, I. Chinn, J. S. Orange, Copa Syndrome: a Novel Autosomal Dominant Immune Dysregulatory Disease. J Clin Immunol 36, 377-387 (2016).

38. Q. Yang, J. Qin, G. Sun, C. Qiu, D. Jiang, H. Ye, X. Wang, L. Dai, J. Zhu, P. Wang, J. Zhang, Discovery and Validation of Serum Autoantibodies Against Tumor-Associated Antigens as Biomarkers in Gastric Adenocarcinoma Based on the Focused Protein Arrays. Clin Transl Gastroenterol 12, e00284 (2020). 
39. H. S. Hong, W. H. Chung, S. I. Hung, M. J. Chen, S. H. Lee, L. C. Yang, Clinical association of anti-golgi autoantibodies and their autoantigens. Scand J Immunol 59, 79-87 (2004).

40. R. Dummer, A. Mittelman, F. P. Fanizzi, G. Lucchese, J. Willers, D. Kanduc, Non-self-discrimination as a driving concept in the identification of an immunodominant HMW-MAA epitopic peptide sequence by autoantibodies from melanoma cancer patients. Int J Cancer 111, 720-726 (2004).

41. V. Vetvicka, M. Fusek, Cathepsin D: Autoantibody profiling as a diagnostic marker for cancers. World J Clin Oncol 4, 1-3 (2013).

42. J. Pitsch, D. Kamalizade, A. Braun, J. C. Kuehn, P. E. Gulakova, T. Rüber, G. Lubec, D. Dietrich, R. von Wrede, C. Helmstaedter, R. Surges, C. E. Elger, E. Hattingen, H. Vatter, S. Schoch, A. J. Becker, Drebrin Autoantibodies in Patients with Seizures and Suspected Encephalitis. Ann Neurol 87, 869-884 (2020).

43. C. A. Brandsma, H. A. Kerstjens, W. H. van Geffen, M. Geerlings, D. S. Postma, M. N. Hylkema, W. Timens, Differential switching to IgG and IgA in active smoking COPD patients and healthy controls. Eur Respir J 40, 313-321 (2012).

44. M. J. Fritzler, J. C. Hamel, R. L. Ochs, E. K. Chan, Molecular characterization of two human autoantigens: unique cDNAs encoding $95-$ and $160-\mathrm{kD}$ proteins of a putative family in the Golgi complex. The Journal of experimental medicine 178, 49-62 (1993).

45. R. H. Scofield, Do we need new autoantibodies in lupus? Arthritis research \& therapy 12, 120 (2010).

46. D. R. Fregeau, T. Prindiville, R. L. Coppel, M. Kaplan, E. R. Dickson, M. E. Gershwin, Inhibition of alpha-ketoglutarate dehydrogenase activity by a distinct population of autoantibodies recognizing dihydrolipoamide succinyltransferase in primary biliary cirrhosis. Hepatology 11, 975-981 (1990).

47. M. Oka, S. Sato, H. Soda, M. Fukuda, S. Kawabata, K. Nakatomi, K. Shiozawa, Y. Nakamura, K. Ohtsuka, S. Kohno, Autoantibody to heat shock protein Hsp40 in sera of lung cancer patients. Japanese journal of cancer research : Gann 92, 316-320 (2001).

48. M. M. Harper, D. Rudd, K. J. Meyer, A. G. Kanthasamy, V. Anantharam, A. A. Pieper, E. Vázquez-Rosa, M. K. Shin, K. Chaubey, Y. Koh, L. P. Evans, A. G. Bassuk, M. G. Anderson, L. Dutca, I. T. Kudva, M. John, Identification of chronic brain protein changes and protein targets of serum auto-antibodies after blast-mediated traumatic brain injury. Heliyon 6, e03374 (2020).

49. E. G. Kim, S. H. Kwak, D. Hwang, E. C. Yi, K. S. Park, B. K. Koo, K. M. Kim, The Level of Autoantibodies Targeting Eukaryote Translation Elongation Factor $1 \alpha 1$ and Ubiquitin-Conjugating Enzyme 2L3 in Nondiabetic Young Adults. Diabetes Metab J 40, 154-160 (2016).

50. C. J. Mooney, E. J. Dunphy, B. Stone, D. G. McNeel, Identification of autoantibodies elicited in a patient with prostate cancer presenting as dermatomyositis. Int J Urol 13, 211-217 (2006).

51. F. Fernández-Madrid, N. Tang, H. Alansari, J. L. Granda, L. Tait, K. C. Amirikia, M. Moroianu, X. Wang, R. L. Karvonen, Autoantibodies to Annexin XI-A and Other Autoantigens in the Diagnosis of Breast Cancer. Cancer research 64, 5089-5096 (2004).

52. M. Bach, G. Winkelmann, R. Luhrmann, 20S small nuclear ribonucleoprotein U5 shows a surprisingly complex protein composition. Proceedings of the National Academy of Sciences of the United States of America 86, 6038-6042 (1989).

53. E. A. Waterman, D. J. Gawkrodger, P. F. Watson, A. P. Weetman, E. H. Kemp, Autoantigens in vitiligo identified by the serological selection of a phage-displayed melanocyte cDNA expression library. The Journal of investigative dermatology 130, 230-240 (2010).

54. C. K. Heo, H. M. Hwang, H. J. Lee, S. S. Kwak, J. S. Yoo, D. Y. Yu, K. J. Lim, S. Lee, E. W. Cho, Serum anti-EIF3A autoantibody as a potential diagnostic marker for hepatocellular carcinoma. Sci Rep 9, 11059 (2019).

55. Z. Betteridge, H. Chinoy, J. Vencovsky, J. Winer, K. Putchakayala, P. Ho, I. Lundberg, K. Danko, R. Cooper, N. McHugh, Identification of a novel autoantigen eukaryotic initiation factor 3 associated with polymyositis. Rheumatology (Oxford, England) 59, 1026-1030 (2020). 
56. G. Suwarnalata, A. H. Tan, H. Isa, R. Gudimella, A. Anwar, M. F. Loke, S. Mahadeva, S. Y. Lim, J. Vadivelu, Augmentation of Autoantibodies by Helicobacter pylori in Parkinson's Disease Patients May Be Linked to Greater Severity. PloS one 11, e0153725 (2016).

57. L. B. Nabors, H. M. Furneaux, P. H. King, HuR, a novel target of anti-Hu antibodies, is expressed in non-neural tissues. J Neuroimmunol 92, 152-159 (1998).

58. S. Moscato, F. Pratesi, A. Sabbatini, D. Chimenti, M. Scavuzzo, R. Passatino, S. Bombardieri, A. Giallongo, P. Migliorini, Surface expression of a glycolytic enzyme, alpha-enolase, recognized by autoantibodies in connective tissue disorders. Eur J Immunol 30, 3575-3584 (2000).

59. D. T. O'Dwyer, V. Clifton, A. Hall, R. Smith, P. J. Robinson, P. A. Crock, Pituitary autoantibodies in lymphocytic hypophysitis target both gamma- and alpha-Enolase - a link with pregnancy? Archives of physiology and biochemistry 110, 94-98 (2002).

60. I. N. Targoff, E. P. Trieu, F. W. Miller, Reaction of anti-OJ autoantibodies with components of the multi-enzyme complex of aminoacyl-tRNA synthetases in addition to isoleucyl-tRNA synthetase. The Journal of clinical investigation 91, 2556-2564 (1993).

61. M. Garranzo-Asensio, P. San Segundo-Acosta, C. Povés, M. J. Fernández-Aceñero, J. MartínezUseros, A. Montero-Calle, G. Solís-Fernández, M. Sanchez-Martinez, N. Rodríguez, M. Cerón, S. Fernandez-Diez, G. Domínguez, V. de Los Ríos, A. Peláez-García, A. Guzmán-Aránguez, R. Barderas, Identification of tumor-associated antigens with diagnostic ability of colorectal cancer by in-depth immunomic and seroproteomic analysis. Journal of proteomics 214, 103635 (2020).

62. C. Leveque, T. Hoshino, P. David, Y. Shoji-Kasai, K. Leys, A. Omori, B. Lang, O. el Far, K. Sato, N. Martin-Moutot, et al., The synaptic vesicle protein synaptotagmin associates with calcium channels and is a putative Lambert-Eaton myasthenic syndrome antigen. Proceedings of the National Academy of Sciences of the United States of America 89, 3625-3629 (1992).

63. C. K. Heo, M. K. Woo, D. Y. Yu, J. Y. Lee, J. S. Yoo, H. S. Yoo, J. H. Ko, J. M. Kim, J. Y. Choi, I. G. Kim, S. G. Paik, E. W. Cho, Identification of autoantibody against fatty acid synthase in hepatocellular carcinoma mouse model and its application to diagnosis of HCC. Int J Oncol 36, 1453-1459 (2010).

64. S. Forti, M. J. Scanlan, A. Invernizzi, F. Castiglioni, S. Pupa, R. Agresti, R. Fontanelli, D. Morelli, L. J. Old, S. M. Pupa, S. Ménard, Identification of breast cancer-restricted antigens by antibody screening of SKBR3 cDNA library using a preselected patient's serum. Breast cancer research and treatment 73, 245-256 (2002).

65. J. Kamhieh-Milz, V. Sterzer, H. Celik, O. Khorramshahi, R. Fadl Hassan Moftah, A. Salama, Identification of novel autoantigens via mass spectroscopy-based antibody-mediated identification of autoantigens (MS-AMIDA) using immune thrombocytopenic purpura (ITP) as a model disease. Journal of proteomics 157, 59-70 (2017).

66. M. Adachi-Hayama, A. Adachi, N. Shinozaki, T. Matsutani, T. Hiwasa, M. Takiguchi, N. Saeki, Y. Iwadate, Circulating anti-filamin $\mathrm{C}$ autoantibody as a potential serum biomarker for low-grade gliomas. BMC Cancer 14, 452 (2014).

67. W. Y. Wang, C. W. Twu, Y. C. Liu, H. H. Lin, C. J. Chen, J. C. Lin, Fibronectin promotes nasopharyngeal cancer cell motility and proliferation. Biomed Pharmacother 109, 1772-1784 (2019).

68. X. Dong, M. Yang, H. Sun, J. Lü, Z. Zheng, Z. Li, L. Zhong, Combined measurement of CA 15-3 with novel autoantibodies improves diagnostic accuracy for breast cancer. Onco Targets Ther 6, 273-279 (2013).

69. Y. Kit, M. Starykovych, M. Vajrychova, J. Lenco, D. Zastavna, R. Stoika, Detection of novel autoantigens in patients with recurrent miscarriage: description of an approach and preliminary findings. Croat Med J 55, 259-264 (2014).

70. F. Delunardo, D. Soldati, V. Bellisario, A. Berry, S. Camerini, M. Crescenzi, C. Alessandri, F. Conti, F. Ceccarelli, A. Francia, G. Valesini, F. Cirulli, A. Siracusano, A. Siracusano, C. Niolu, I. Alex Rubino, E. 
Ortona, P. Margutti, Anti-GAPDH Autoantibodies as a Pathogenic Determinant and Potential Biomarker of Neuropsychiatric Diseases. Arthritis Rheumatol 68, 2708-2716 (2016).

71. A. Kiyota, S. Iwama, Y. Sugimura, S. Takeuchi, H. Takagi, N. Iwata, K. Nakashima, H. Suzuki, T. Nishioka, T. Kato, A. Enomoto, H. Arima, K. Kaibuchi, Y. Oiso, Identification of the novel autoantigen candidate Rab GDP dissociation inhibitor alpha in isolated adrenocorticotropin deficiency. Endocrine journal 62, 153-160 (2015).

72. O. Massa, M. Alessio, L. Russo, G. Nardo, V. Bonetto, F. Bertuzzi, A. Paladini, D. lafusco, P. Patera, G. Federici, T. Not, C. Tiberti, R. Bonfanti, F. Barbetti, Serological Proteome Analysis (SERPA) as a tool for the identification of new candidate autoantigens in type 1 diabetes. Journal of proteomics $\mathbf{8 2}$, 263-273 (2013).

73. J. M. Chung, Y. Jung, Y. P. Kim, J. Song, S. Kim, J. Y. Kim, M. Kwon, J. H. Yoon, M. D. Kim, J. K. Lee, D. Y. Chung, S. Y. Lee, J. Kang, H. C. Kang, Identification of the Thioredoxin-Like 2 Autoantibody as a Specific Biomarker for Triple-Negative Breast Cancer. Journal of breast cancer 21, 87-90 (2018).

74. S. Biswas, S. Sharma, A. Saroha, D. S. Bhakuni, R. Malhotra, M. Zahur, M. Oellerich, H. R. Das, A. R. Asif, Identification of novel autoantigen in the synovial fluid of rheumatoid arthritis patients using an immunoproteomics approach. PloS one 8, e56246 (2013).

75. R. L. Rubin, S. A. Bell, R. W. Burlingame, Autoantibodies associated with lupus induced by diverse drugs target a similar epitope in the $(\mathrm{H} 2 \mathrm{~A}-\mathrm{H} 2 \mathrm{~B})-\mathrm{DNA}$ complex. The Journal of clinical investigation 90, 165-173 (1992).

76. R. W. Burlingame, M. L. Boey, G. Starkebaum, R. L. Rubin, The central role of chromatin in autoimmune responses to histones and DNA in systemic lupus erythematosus. The Journal of clinical investigation 94, 184-192 (1994).

77. H. Nahamura, K. Yoshida, Y. Kishima, H. Enomoto, H. Uyama, T. Kuroda, Y. Okuda, T. Hirotani, H. Ito, I. Kawase, Circulating auto-antibody against hepatoma-derived growth factor (HDGF) in patients with ulcerative colitis. Hepatogastroenterology 51, 470-475 (2004).

78. J. Wesierska-Gadek, E. Penner, H. Lindner, E. Hitchman, G. Sauermann, Autoantibodies against different histone $\mathrm{H} 1$ subtypes in systemic lupus erythematosus sera. Arthritis and rheumatism 33, 1273-1278 (1990).

79. S. V. Baranova, P. S. Dmitrienok, N. V. Ivanisenko, V. N. Buneva, G. A. Nevinsky, Antibodies to H2a and $\mathrm{H} 2 \mathrm{~b}$ histones from the sera of HIV-infected patients catalyze site-specific degradation of these histones. Molecular bioSystems 13, 1090-1101 (2017).

80. M. Bruschi, M. Galetti, R. A. Sinico, G. Moroni, A. Bonanni, A. Radice, A. Tincani, F. Pratesi, P. Migliorini, C. Murtas, F. Franceschini, B. Trezzi, F. Brunini, R. Gatti, R. Tardanico, G. Barbano, G. Piaggio, P. Messa, P. Ravani, F. Scolari, G. Candiano, A. Martini, L. Allegri, G. M. Ghiggeri, Glomerular Autoimmune Multicomponents of Human Lupus Nephritis In Vivo (2): Planted Antigens. J Am Soc Nephrol 26, 1905-1924 (2015).

81. C. C. van Bavel, J. Dieker, S. Muller, J. P. Briand, M. Monestier, J. H. Berden, J. van der Vlag, Apoptosis-associated acetylation on histone $\mathrm{H} 2 \mathrm{~B}$ is an epitope for lupus autoantibodies. Molecular immunology 47, 511-516 (2009).

82. S. V. Baranova, P. S. Dmitrenok, A. D. Zubkova, N. V. Ivanisenko, E. S. Odintsova, V. N. Buneva, G. A. Nevinsky, Antibodies against $\mathrm{H} 3$ and $\mathrm{H} 4$ histones from the sera of HIV-infected patients catalyze site-specific degradation of these histones. Journal of molecular recognition : JMR 31, e2703 (2018).

83. S. Barnay-Verdier, L. Fattoum, C. Borde, S. Kaveri, S. Gibot, V. Maréchal, Emergence of autoantibodies to HMGB1 is associated with survival in patients with septic shock. Intensive care medicine 37, 957-962 (2011).

84. C. Guarneri, M. Aguennouz, F. Guarneri, F. Polito, S. Benvenga, S. P. Cannavo, Autoimmunity to heterogeneous nuclear ribonucleoprotein $A 1$ in psoriatic patients and correlation with disease severity. J Dtsch Dermatol Ges 16, 1103-1107 (2018). 
85. M. F. Konig, J. T. Giles, P. A. Nigrovic, F. Andrade, Antibodies to native and citrullinated RA33 (hnRNP A2/B1) challenge citrullination as the inciting principle underlying loss of tolerance in rheumatoid arthritis. Annals of the rheumatic diseases 75, 2022-2028 (2016).

86. S. Siapka, M. Patrinou-Georgoula, P. G. Vlachoyiannopoulos, A. Guialis, Multiple specificities of autoantibodies against hnRNP A/B proteins in systemic rheumatic diseases and hnRNP $L$ as an associated novel autoantigen. Autoimmunity 40, 223-233 (2007).

87. N. H. Heegaard, M. R. Larsen, T. Muncrief, A. Wiik, P. Roepstorff, Heterogeneous nuclear ribonucleoproteins $\mathrm{C} 1 / \mathrm{C} 2$ identified as autoantigens by biochemical and mass spectrometric methods. Arthritis research 2, 407-414 (2000).

88. K. Skriner, W. Hueber, E. Süleymanoglu, E. Höfler, V. Krenn, J. Smolen, G. Steiner, AUF1, the regulator of tumor necrosis factor alpha messenger RNA decay, is targeted by autoantibodies of patients with systemic rheumatic diseases. Arthritis and rheumatism 58, 511-520 (2008).

89. Y. Zhang, H. Zhao, B. Liu, L. Li, L. Zhang, M. Bao, X. Ji, X. He, J. Yi, P. Chen, C. Lu, A. Lu, Low Level Antibodies Against Alpha-Tropomyosin Are Associated With Increased Risk of Coronary Heart Disease. Frontiers in pharmacology 11, 195 (2020).

90. K. Op De Beéck, L. Maes, K. Van den Bergh, R. Derua, E. Waelkens, K. Van Steen, P. Vermeersch, R. Westhovens, K. De Vlam, P. Verschueren, H. Hooijkaas, D. Blockmans, X. Bossuyt, Heterogeneous nuclear RNPs as targets of autoantibodies in systemic rheumatic diseases. Arthritis and rheumatism 64, 213-221 (2012).

91. L. Yang, M. Fujimoto, H. Murota, S. Serada, M. Fujimoto, H. Honda, K. Yamada, K. Suzuki, A. Nishikawa, Y. Hosono, Y. Yoneda, K. Takehara, Y. Imura, T. Mimori, T. Takeuchi, I. Katayama, T. Naka, Proteomic identification of heterogeneous nuclear ribonucleoprotein $\mathrm{K}$ as a novel cold-associated autoantigen in patients with secondary Raynaud's phenomenon. Rheumatology (Oxford, England) 54, 349-358 (2015).

92. W. Hassfeld, E. K. Chan, D. A. Mathison, D. Portman, G. Dreyfuss, G. Steiner, E. M. Tan, Molecular definition of heterogeneous nuclear ribonucleoprotein R (hnRNP R) using autoimmune antibody: immunological relationship with hnRNP P. Nucleic Acids Res 26, 439-445 (1998).

93. L. Harlow, I. O. Rosas, B. R. Gochuico, T. R. Mikuls, P. F. Dellaripa, C. V. Oddis, D. P. Ascherman, Identification of citrullinated hsp90 isoforms as novel autoantigens in rheumatoid arthritisassociated interstitial lung disease. Arthritis and rheumatism 65, 869-879 (2013).

94. H. Y. Qin, J. L. Mahon, M. A. Atkinson, P. Chaturvedi, E. Lee-Chan, B. Singh, Type 1 diabetes alters anti-hsp90 autoantibody isotype. J Autoimmun 20, 237-245 (2003).

95. C. Cid, I. Regidor, A. Alcazar, Anti-heat shock protein 90beta antibodies are detected in patients with multiple sclerosis during remission. J Neuroimmunol 184, 223-226 (2007).

96. S. Suzuki, K. Utsugisawa, K. Iwasa, T. Satoh, Y. Nagane, H. Yoshikawa, M. Kuwana, N. Suzuki, Autoimmunity to endoplasmic reticulum chaperone GRP94 in myasthenia gravis. J Neuroimmunol 237, 87-92 (2011).

97. M. Chen, F. Aosai, H. S. Mun, K. Norose, H. Hata, A. Yano, Anti-HSP70 autoantibody formation by B1 cells in Toxoplasma gondii-infected mice. Infect Immun 68, 4893-4899 (2000).

98. F. Shimizu, K. L. Schaller, G. P. Owens, A. C. Cotleur, D. Kellner, Y. Takeshita, B. Obermeier, T. J. Kryzer, Y. Sano, T. Kanda, V. A. Lennon, R. M. Ransohoff, J. L. Bennett, Glucose-regulated protein 78 autoantibody associates with blood-brain barrier disruption in neuromyelitis optica. Sci Trans/ Med 9, (2017).

99. A. lannaccone, F. Giorgianni, D. D. New, T. J. Hollingsworth, A. Umfress, A. H. Alhatem, I. Neeli, N. I. Lenchik, B. J. Jennings, J. I. Calzada, S. Satterfield, D. Mathews, R. I. Diaz, T. Harris, K. C. Johnson, S. Charles, S. B. Kritchevsky, I. C. Gerling, S. Beranova-Giorgianni, M. Z. Radic, A. B. C. S. Health, Circulating Autoantibodies in Age-Related Macular Degeneration Recognize Human Macular Tissue 
Antigens Implicated in Autophagy, Immunomodulation, and Protection from Oxidative Stress and Apoptosis. PloS one 10, e0145323 (2015).

100. I. Korneeva, A. M. Bongiovanni, M. Girotra, T. A. Caputo, S. S. Witkin, Serum antibodies to the 27kd heat shock protein in women with gynecologic cancers. Am J Obstet Gynecol 183, 18-21 (2000).

101. H. Fillit, S. Shibata, T. Sasaki, H. Spiera, L. D. Kerr, M. Blake, Autoantibodies to the protein core of vascular basement membrane heparan sulfate proteoglycan in systemic lupus erythematosus. Autoimmunity 14, 243-249 (1993).

102. H. D. Bremer, N. Landegren, R. Sjoberg, A. Hallgren, S. Renneker, E. Lattwein, D. Leonard, M. L. Eloranta, L. Ronnblom, G. Nordmark, P. Nilsson, G. Andersson, I. Lilliehook, K. Lindblad-Toh, O. Kampe, $\mathrm{H}$. Hansson-Hamlin, ILF2 and ILF3 are autoantigens in canine systemic autoimmune disease. Sci Rep 8, 4852 (2018).

103. S. Presslauer, G. Hinterhuber, K. Cauza, R. Horvat, K. Rappersberger, K. Wolff, D. Foedinger, RasGAPlike protein IQGAP1 is expressed by human keratinocytes and recognized by autoantibodies in association with bullous skin disease. The Journal of investigative dermatology 120, 365-371 (2003).

104. T. O. Ola, P. A. Biro, M. I. Hawa, J. Ludvigsson, M. Locatelli, M. A. Puglisi, G. F. Bottazzo, A. Fierabracci, Importin beta: a novel autoantigen in human autoimmunity identified by screening random peptide libraries on phage. J Autoimmun 26, 197-207 (2006).

105. Y. Lu, P. Ye, S. L. Chen, E. M. Tan, E. K. Chan, Identification of kinectin as a novel Behçet's disease autoantigen. Arthritis research \& therapy 7, R1133-1139 (2005).

106. J. Inagaki, A. Kondo, L. R. Lopez, Y. Shoenfeld, E. Matsuura, Pregnancy loss and endometriosis: pathogenic role of anti-laminin-1 autoantibodies. Annals of the New York Academy of Sciences 1051, 174-184 (2005).

107. C. J. Peutz-Kootstra, K. Hansen, E. De Heer, C. K. Abrass, J. A. Bruijn, Differential expression of laminin chains and anti-laminin autoantibodies in experimental lupus nephritis. The Journal of pathology 192, 404-412 (2000).

108. K. Ueda, T. Nakanishi, A. Shimizu, T. Takubo, N. Matsuura, Identification of L-plastin autoantibody in plasma of patients with non-Hodgkin's lymphoma using a proteomics-based analysis. Ann Clin Biochem 45, 65-69 (2008).

109. D. Lutomski, R. Joubert-Caron, C. Lefebure, J. Salama, C. Belin, D. Bladier, M. Caron, Anti-galectin-1 autoantibodies in serum of patients with neurological diseases. Clin Chim Acta 262, 131-138 (1997).

110. K. N. Konstantinov, Z. Galcheva-Gargova, M. Hoier-Madsen, A. Wiik, S. Ullman, P. Halberg, G. L. Vejlsgaard, Autoantibodies to lamins $A$ and $C$ in sera of patients showing peripheral fluorescent antinuclear antibody pattern on HEP-2 cells. The Journal of investigative dermatology 95, 304-308 (1990).

111. A. von Mikecz, K. Konstantinov, D. S. Buchwald, L. Gerace, E. M. Tan, High frequency of autoantibodies to insoluble cellular antigens in patients with chronic fatigue syndrome. Arthritis and rheumatism 40, 295-305 (1997).

112. J. Brito, G. Biamonti, R. Caporali, C. Montecucco, Autoantibodies to human nuclear lamin B2 protein. Epitope specificity in different autoimmune diseases. Journal of immunology (Baltimore, Md. : 1950) 153, 2268-2277 (1994).

113. M. Tanaka, M. Kishimura, S. Ozaki, F. Osakada, H. Hashimoto, M. Okubo, M. Murakami, K. Nakao, Cloning of novel soluble gp130 and detection of its neutralizing autoantibodies in rheumatoid arthritis. The Journal of clinical investigation 106, 137-144 (2000).

114. A. Gadoth, T. J. Kryzer, J. Fryer, A. McKeon, V. A. Lennon, S. J. Pittock, Microtubule-associated protein 1B: Novel paraneoplastic biomarker. Ann Neurol 81, 266-277 (2017).

115. K. Suzuki, T. Nagao, M. Itabashi, Y. Hamano, R. Sugamata, Y. Yamazaki, W. Yumura, S. Tsukita, P. C. Wang, T. Nakayama, K. Suzuki, A novel autoantibody against moesin in the serum of patients with MPO-ANCA-associated vasculitis. Nephrol Dial Transplant 29, 1168-1177 (2014). 
116. D. Marinou, G. Katsifis, G. Barouta, C. Liaskos, L. I. Sakkas, A. Tsakris, J. G. Routsias, Major vault protein/lung resistance related protein: a novel biomarker for rheumatoid arthritis. Clinical and experimental rheumatology, (2020).

117. C. A. von Muhlen, E. K. Chan, C. L. Peebles, H. Imai, K. Kiyosawa, E. M. Tan, Non-muscle myosin as target antigen for human autoantibodies in patients with hepatitis $C$ virus-associated chronic liver diseases. Clinical and experimental immunology 100, 67-74 (1995).

118. B. A. Zasońska, H. Hlídková, E. Petrovský, S. Myronovskij, T. Nehrych, N. Negrych, M. Shorobura, V. Antonyuk, R. Stoika, Y. Kit, D. Horák, Monodisperse magnetic poly(glycidyl methacrylate) microspheres for isolation of autoantibodies with affinity for the $46 \mathrm{kDa}$ form of unconventional Myo1C present in autoimmune patients. Mikrochimica acta 185, 262 (2018).

119. R. Mossabeb, S. Seiberler, I. Mittermann, R. Reininger, S. Spitzauer, S. Natter, P. Verdino, W. Keller, D. Kraft, R. Valenta, Characterization of a novel isoform of alpha-nascent polypeptide-associated complex as IgE-defined autoantigen. The Journal of investigative dermatology 119, 820-829 (2002).

120. I. N. Batova, R. T. Richardson, E. E. Widgren, M. G. O'Rand, Analysis of the autoimmune epitopes on human testicular NASP using recombinant and synthetic peptides. Clinical and experimental immunology 121, 201-209 (2000).

121. Z. Qin, B. Lavingia, Y. Zou, P. Stastny, Antibodies against nucleolin in recipients of organ transplants. Transplantation 92, 829-835 (2011).

122. K. Cortés-Sarabia, C. Rodríguez-Nava, Y. Medina-Flores, O. Mata-Ruíz, J. E. López-Meza, M. D. Gómez-Cervantes, I. Parra-Rojas, B. Illades-Aguiar, E. Flores-Alfaro, A. Vences-Velázquez, Production and characterization of a monoclonal antibody against the sialidase of Gardnerella vaginalis using a synthetic peptide in a MAP8 format. Appl Microbiol Biotechnol 104, 6173-6183 (2020).

123. F. Le Naour, F. Brichory, D. E. Misek, C. Brechot, S. M. Hanash, L. Beretta, A distinct repertoire of autoantibodies in hepatocellular carcinoma identified by proteomic analysis. Molecular \& cellular proteomics : MCP 1, 197-203 (2002).

124. J. R. Underwood, X. F. Csar, B. A. Veitch, M. T. Hearn, Characterization of the specificity of a naturally-occurring monoclonal anti-thymocyte autoantibody derived from an unimmunized, neonatal Balb/c mouse. Thymus 21, 199-219 (1993).

125. B. Brankin, T. C. Skaar, M. Brotzman, B. Trock, R. Clarke, Autoantibodies to the nuclear phosphoprotein nucleophosmin in breast cancer patients. Cancer Epidemiol Biomarkers Prev 7, 1109-1115 (1998).

126. L. E. Andrade, E. K. Chan, C. L. Peebles, E. M. Tan, Two major autoantigen-antibody systems of the mitotic spindle apparatus. Arthritis and rheumatism 39, 1643-1653 (1996).

127. R. L. Ochs, T. W. Stein, Jr., E. K. Chan, M. Ruutu, E. M. Tan, cDNA cloning and characterization of a novel nucleolar protein. Molecular biology of the cell 7, 1015-1024 (1996).

128. S. Nagayama, T. Yokoi, H. Tanaka, Y. Kawaguchi, T. Shirasaka, T. Kamataki, Occurrence of autoantibody to protein disulfide isomerase in patients with hepatic disorder. J Toxicol Sci 19, 163169 (1994).

129. A. Becker, N. Ludwig, A. Keller, B. Tackenberg, C. Eienbroker, W. H. Oertel, K. Fassbender, E. Meese, K. Ruprecht, Myasthenia gravis: analysis of serum autoantibody reactivities to 1827 potential human autoantigens by protein macroarrays. PloS one 8, e58095 (2013).

130. A. K. Houng, L. Maggini, C. Y. Clement, G. L. Reed, Identification and structure of activated-platelet protein-1, a protein with RNA-binding domain motifs that is expressed by activated platelets. European journal of biochemistry 243, 209-218 (1997).

131. K. Kaneda, Y. Takasaki, K. Takeuchi, H. Yamada, M. Nawata, M. Matsushita, R. Matsudaira, K. Ikeda, K. Yamanaka, H. Hashimoto, Autoimmune response to proteins of proliferating cell nuclear antigen 
multiprotein complexes in patients with connective tissue diseases. The Journal of rheumatology 31, 2142-2150 (2004).

132. C. Caorsi, E. Niccolai, M. Capello, R. Vallone, M. S. Chattaragada, B. Alushi, A. Castiglione, G. Ciccone, A. Mautino, P. Cassoni, L. De Monte, S. M. Álvarez-Fernández, A. Amedei, M. Alessio, F. Novelli, Protein disulfide isomerase A3-specific Th1 effector cells infiltrate colon cancer tissue of patients with circulating anti-protein disulfide isomerase A3 autoantibodies. Transl Res 171, 17-28.e11-12 (2016).

133. D. C. Chang, P. Piaggi, R. L. Hanson, W. C. Knowler, C. Bogardus, J. Krakoff, Autoantibodies against PFDN2 are associated with an increased risk of type 2 diabetes: A case-control study. Diabetes Metab Res Rev 33, (2017).

134. P. J. Orchard, D. R. Nascene, A. Gupta, M. E. Taisto, L. Higgins, T. W. Markowski, T. C. Lund, Cerebral adrenoleukodystrophy is associated with loss of tolerance to profilin. Eur J Immunol 49, 947-953 (2019).

135. G. Frampton, S. Moriya, J. D. Pearson, D. A. Isenberg, F. J. Ward, T. A. Smith, A. Panayiotou, N. A. Staines, J. J. Murphy, Identification of candidate endothelial cell autoantigens in systemic lupus erythematosus using a molecular cloning strategy: a role for ribosomal P protein PO as an endothelial cell autoantigen. Rheumatology (Oxford, England) 39, 1114-1120 (2000).

136. M. Wieczorek, A. Czernik, Paraneoplastic pemphigus: a short review. Clin Cosmet Investig Dermatol 9, 291-295 (2016).

137. A. Kratz, M. W. Harding, J. Craft, C. G. Mackworth-Young, R. E. Handschumacher, Autoantibodies against cyclophilin in systemic lupus erythematosus and Lyme disease. Clinical and experimental immunology 90, 422-427 (1992).

138. L. H. Lin, Y. W. Xu, L. S. Huang, C. Q. Hong, T. T. Zhai, L. D. Liao, W. J. Lin, L. Y. Xu, K. Zhang, E. M. Li, Y. H. Peng, Serum proteomic-based analysis identifying autoantibodies against PRDX2 and PRDX3 as potential diagnostic biomarkers in nasopharyngeal carcinoma. Clin Proteomics 14, 6 (2017).

139. S. Kobayashi, T. Hiwasa, T. Arasawa, A. Kagaya, S. Ishii, H. Shimada, M. Ito, M. Suzuki, M. Kano, B. Rahmutulla, K. Kitamura, Y. Sawabe, H. Shin, M. Takiguchi, F. Nomura, H. Matsubara, K. Matsushita, Identification of specific and common diagnostic antibody markers for gastrointestinal cancers by SEREX screening using testis CDNA phage library. Oncotarget 9, 18559-18569 (2018).

140. C. Schild-Poulter, A. Su, A. Shih, O. P. Kelly, M. J. Fritzler, R. Goldstein, R. J. Hache, Association of autoantibodies with $\mathrm{Ku}$ and DNA repair proteins in connective tissue diseases. Rheumatology (Oxford, England) 47, 165-171 (2008).

141. E. Feist, U. Kuckelkorn, T. Dörner, H. Dönitz, S. Scheffler, F. Hiepe, P. M. Kloetzel, G. R. Burmester, Autoantibodies in primary Sjögren's syndrome are directed against proteasomal subunits of the alpha and beta type. Arthritis and rheumatism 42, 697-702 (1999).

142. E. Feist, T. Dorner, U. Kuckelkorn, G. Schmidtke, B. Micheel, F. Hiepe, G. R. Burmester, P. M. Kloetzel, Proteasome alpha-type subunit $\mathrm{C} 9$ is a primary target of autoantibodies in sera of patients with myositis and systemic lupus erythematosus. The Journal of experimental medicine 184, 1313-1318 (1996).

143. C. Bohring, W. Krause, Characterization of spermatozoa surface antigens by antisperm antibodies and its influence on acrosomal exocytosis. Am J Reprod Immunol 50, 411-419 (2003).

144. K. Sugimoto, T. Hiwasa, K. Shibuya, S. Hirano, M. Beppu, S. Isose, K. Arai, M. Takiguchi, S. Kuwabara, M. Mori, Novel autoantibodies against the proteasome subunit PSMA7 in amyotrophic lateral sclerosis. J Neuroimmunol 325, 54-60 (2018).

145. S. Scheffler, U. Kuckelkorn, K. Egerer, T. Dörner, K. Reiter, A. Soza, G. R. Burmester, E. Feist, Autoimmune reactivity against the 20S-proteasome includes immunosubunits LMP2 (beta1i), MECL1 (beta2i) and LMP7 (beta5i). Rheumatology (Oxford, England) 47, 622-626 (2008). 
146. Z. Mojtahedi, A. Safaei, Z. Yousefi, A. Ghaderi, Immunoproteomics of HER2-positive and HER2negative breast cancer patients with positive lymph nodes. OMICS 15, 409-418 (2011).

147. C. Montecucco, R. Caporali, F. Cobianchi, G. Biamonti, Identification of autoantibodies to the I protein of the heterogeneous nuclear ribonucleoprotein complex in patients with systemic sclerosis. Arthritis and rheumatism 39, 1669-1676 (1996).

148. D. F. Fiorentino, M. Presby, A. N. Baer, M. Petri, K. E. Rieger, M. Soloski, A. Rosen, A. L. Mammen, L. Christopher-Stine, L. Casciola-Rosen, PUF60: a prominent new target of the autoimmune response in dermatomyositis and Sjögren's syndrome. Annals of the rheumatic diseases 75, 1145-1151 (2016).

149. I. Schepens, F. Jaunin, N. Begre, U. Läderach, K. Marcus, T. Hashimoto, B. Favre, L. Borradori, The protease inhibitor alpha-2-macroglobulin-like-1 is the p170 antigen recognized by paraneoplastic pemphigus autoantibodies in human. PloS one 5, e12250 (2010).

150. S. Thébault, D. Gilbert, M. Hubert, L. Drouot, N. Machour, C. Lange, R. Charlionet, F. Tron, Orderly pattern of development of the autoantibody response in (New Zealand White x BXSB)F1 lupus mice: characterization of target antigens and antigen spreading by two-dimensional gel electrophoresis and mass spectrometry. Journal of immunology (Baltimore, Md. : 1950) 169, 4046-4053 (2002).

151. J. H. Vaughan, J. R. Valbracht, M. D. Nguyen, H. H. Handley, R. S. Smith, K. Patrick, G. H. Rhodes, Epstein-Barr virus-induced autoimmune responses. I. Immunoglobulin $\mathrm{M}$ autoantibodies to proteins mimicking and not mimicking Epstein-Barr virus nuclear antigen-1. The Journal of clinical investigation 95, 1306-1315 (1995).

152. K. Doe, K. Nozawa, K. Hiruma, Y. Yamada, Y. Matsuki, S. Nakano, M. Ogasawara, H. Nakano, T. Ikeda, T. Ikegami, M. Fujishiro, M. Kawasaki, K. Ikeda, H. Amano, S. Morimoto, H. Ogawa, K. Takamori, I. Sekigawa, Y. Takasaki, Antibody against chromatin assembly factor-1 is a novel autoantibody specifically recognized in systemic lupus erythematosus. Lupus 23, 1031-1041 (2014).

153. M. Wagatsuma, M. Kimura, R. Suzuki, F. Takeuchi, K. Matsuta, H. Watanabe, Ezrin, radixin and moesin are possible auto-immune antigens in rheumatoid arthritis. Molecular immunology 33, 1171-1176 (1996).

154. T. Sato, T. Uchiumi, R. Kominami, M. Arakawa, Autoantibodies specific for the 20-KDal ribosomal large subunit protein L12. Biochemical and biophysical research communications 172, 496-502 (1990).

155. A. Guialis, M. Patrinou-Georgoula, N. Tsifetaki, V. Aidinis, C. E. Sekeris, H. M. Moutsopoulos, Anti-5S RNA/protein (RNP) antibody levels correlate with disease activity in a patient with systemic lupus erythematosus (SLE) nephritis. Clinical and experimental immunology 95, 385-389 (1994).

156. E. Neu, A. H. von Mikecz, P. H. Hemmerich, H. H. Peter, M. Fricke, H. Deicher, E. Genth, U. Krawinkel, Autoantibodies against eukaryotic protein L7 in patients suffering from systemic lupus erythematosus and progressive systemic sclerosis: frequency and correlation with clinical, serological and genetic parameters. The SLE Study Group. Clinical and experimental immunology 100, 198-204 (1995).

157. K. Elkon, E. Bonfa, R. Llovet, W. Danho, H. Weissbach, N. Brot, Properties of the ribosomal P2 protein autoantigen are similar to those of foreign protein antigens. Proceedings of the National Academy of Sciences of the United States of America 85, 5186-5189 (1988).

158. L. Y. Luo, I. Herrera, A. Soosaipillai, E. P. Diamandis, Identification of heat shock protein 90 and other proteins as tumour antigens by serological screening of an ovarian carcinoma expression library. British journal of cancer 87, 339-343 (2002).

159. M. Absi, J. P. La Vergne, A. Marzouki, F. Giraud, D. Rigal, A. M. Reboud, J. P. Reboud, J. C. Monier, Heterogeneity of ribosomal autoantibodies from human, murine and canine connective tissue diseases. Immunology letters 23, 35-41 (1989).

160. K. T. Tycowski, M. D. Shu, J. A. Steitz, A small nucleolar RNA is processed from an intron of the human gene encoding ribosomal protein S3. Genes \& development 7, 1176-1190 (1993). 
161. Z. Betteridge, H. Gunawardena, J. North, J. Slinn, N. McHugh, Identification of a novel autoantibody directed against small ubiquitin-like modifier activating enzyme in dermatomyositis. Arthritis and rheumatism 56, 3132-3137 (2007).

162. A. M. Abreu-Velez, M. S. Howard, K. Hashimoto, T. Hashimoto, Autoantibodies to sweat glands detected by different methods in serum and in tissue from patients affected by a new variant of endemic pemphigus foliaceus. Archives of dermatological research 301, 711-718 (2009).

163. P. Margutti, M. Sorice, F. Conti, F. Delunardo, M. Racaniello, C. Alessandri, A. Siracusano, R. Riganò, E. Profumo, G. Valesini, E. Ortona, Screening of an endothelial cDNA library identifies the C-terminal region of Nedd5 as a novel autoantigen in systemic lupus erythematosus with psychiatric manifestations. Arthritis research \& therapy 7, R896-903 (2005).

164. R. L. Bates, S. J. Payne, S. L. Drury, P. N. Nelson, D. A. Isenberg, J. J. Murphy, G. Frampton, The prevalence and clinical significance of autoantibodies to plasminogen activator inhibitor 1 in systemic lupus erythematosus. Lupus 12, 617-622 (2003).

165. S. Yokota, H. Kubota, Y. Matsuoka, M. Naitoh, D. Hirata, S. Minota, H. Takahashi, N. Fujii, K. Nagata, Prevalence of HSP47 antigen and autoantibodies to HSP47 in the sera of patients with mixed connective tissue disease. Biochemical and biophysical research communications 303, 413-418 (2003).

166. H. M. Hwang, C. K. Heo, H. J. Lee, S. S. Kwak, W. H. Lim, J. S. Yoo, D. Y. Yu, K. J. Lim, J. Y. Kim, E. W. Cho, Identification of anti-SF3B1 autoantibody as a diagnostic marker in patients with hepatocellular carcinoma. J Transl Med 16, 177 (2018).

167. Y. Hosono, R. Nakashima, S. Serada, K. Murakami, Y. Imura, H. Yoshifuji, K. Ohmura, T. Naka, T. Mimori, Splicing factor proline/glutamine-rich is a novel autoantigen of dermatomyositis and associated with anti-melanoma differentiation-associated gene 5 antibody. J Autoimmun 77, 116122 (2017).

168. K. Overzet, T. J. Gensler, S. J. Kim, M. E. Geiger, W. J. van Venrooij, K. M. Pollard, P. Anderson, P. J. Utz, Small nucleolar RNP scleroderma autoantigens associate with phosphorylated serine/arginine splicing factors during apoptosis. Arthritis and rheumatism 43, 1327-1336 (2000).

169. A. M. Yamamoto, Z. Amoura, C. Johannet, A. L. Jeronimo, H. Campos, S. Koutouzov, J. C. Piette, J. F. Bach, Quantitative radioligand assays using de novo-synthesized recombinant autoantigens in connective tissue diseases: new tools to approach the pathogenic significance of anti-RNP antibodies in rheumatic diseases. Arthritis and rheumatism 43, 689-698 (2000).

170. J. D. Huntriss, D. S. Latchman, D. G. Williams, Lupus autoantibodies discriminate between the highly homologous $\mathrm{Sm}$ polypeptides $\mathrm{B} / \mathrm{B}^{\prime}$ and $\mathrm{SmN}$ by binding an epitope restricted to $\mathrm{B} / \mathrm{B}^{\prime}$. Clinical and experimental immunology 92, 263-267 (1993).

171. H. Brahms, J. Raymackers, A. Union, F. de Keyser, L. Meheus, R. Luhrmann, The C-terminal RG dipeptide repeats of the spliceosomal Sm proteins D1 and D3 contain symmetrical dimethylarginines, which form a major B-cell epitope for anti-Sm autoantibodies. The Journal of biological chemistry 275, 17122-17129 (2000).

172. M. T. McClain, P. A. Ramsland, K. M. Kaufman, J. A. James, Anti-sm autoantibodies in systemic lupus target highly basic surface structures of complexed spliceosomal autoantigens. Journal of immunology (Baltimore, Md. : 1950) 168, 2054-2062 (2002).

173. M. Satoh, J. Y. Chan, S. J. Ross, A. Ceribelli, I. Cavazzana, F. Franceschini, Y. Li, W. H. Reeves, E. S. Sobel, E. K. Chan, Autoantibodies to survival of motor neuron complex in patients with polymyositis: immunoprecipitation of $D, E, F$, and $G$ proteins without other components of small nuclear ribonucleoproteins. Arthritis and rheumatism 63, 1972-1978 (2011).

174. M. Garbarz, D. Dhermy, O. Bournier, A. Bezeaud, P. Boivin, Anti-spectrin in sera containing smooth muscle autoantibodies from patients with chronic active hepatitis. Clinical and experimental immunology 43, 87-93 (1981). 
175. A. Zaninoni, C. Vercellati, F. G. Imperiali, A. P. Marcello, B. Fattizzo, E. Fermo, P. Bianchi, C. Grossi, A. Cattaneo, A. Cortelezzi, A. Zanella, W. Barcellini, Detection of red blood cell antibodies in mitogen-stimulated cultures from patients with hereditary spherocytosis. Transfusion 55, 29302938 (2015).

176. P. Santoro, M. De Andrea, G. Migliaretti, C. Trapani, S. Landolfo, M. Gariglio, High prevalence of autoantibodies against the nuclear high mobility group (HMG) protein SSRP1 in sera from patients with systemic lupus erythematosus, but not other rheumatic diseases. The Journal of rheumatology 29, 90-93 (2002).

177. A. Cortini, S. Bembich, L. Marson, E. Cocco, P. Edomi, Identification of novel non-myelin biomarkers in multiple sclerosis using an improved phage-display approach. PloS one 14, e0226162 (2019).

178. Y. Meng, M. Zhang, X. Zhao, Y. Cheng, R. Jia, Y. Wang, X. Sun, Decreased serum thrombospondin-1 and elevation of its autoantibody are associated with multiple exacerbated clinical manifestations in systemic lupus erythematosus. Clinical rheumatology 37, 2707-2714 (2018).

179. M. Muto, M. Mori, T. Hiwasa, M. Takiguchi, Y. Iwadate, A. Uzawa, T. Uchida, H. Masuda, K. Sugimoto, S. Kuwabara, Novel serum autoantibodies against talin1 in multiple sclerosis: Possible pathogenetic roles of the antibodies. J Neuroimmunol 284, 30-36 (2015).

180. A. Schwenzer, X. Jiang, T. R. Mikuls, J. B. Payne, H. R. Sayles, A. M. Quirke, B. M. Kessler, R. Fischer, P. J. Venables, K. Lundberg, K. S. Midwood, Identification of an immunodominant peptide from citrullinated tenascin- $\mathrm{C}$ as a major target for autoantibodies in rheumatoid arthritis. Annals of the rheumatic diseases 75, 1876-1883 (2016).

181. X. Geng, L. Biancone, H. H. Dai, J. J. Lin, N. Yoshizaki, A. Dasgupta, F. Pallone, K. M. Das, Tropomyosin isoforms in intestinal mucosa: production of autoantibodies to tropomyosin isoforms in ulcerative colitis. Gastroenterology 114, 912-922 (1998).

182. R. Gajbhiye, A. Sonawani, S. Khan, A. Suryawanshi, S. Kadam, N. Warty, V. Raut, V. Khole, Identification and validation of novel serum markers for early diagnosis of endometriosis. Hum Reprod 27, 408-417 (2012).

183. A. Kimura, T. Sakurai, M. Yamada, A. Koumura, Y. Hayashi, Y. Tanaka, I. Hozumi, H. Ohtaki, M. Chousa, M. Takemura, M. Seishima, T. Inuzuka, Anti-endothelial cell antibodies in patients with cerebral small vessel disease. Curr Neurovasc Res 9, 296-301 (2012).

184. P. Enarson, J. B. Rattner, Y. Ou, K. Miyachi, T. Horigome, M. J. Fritzler, Autoantigens of the nuclear pore complex. J Mol Med (Berl) 82, 423-433 (2004).

185. X. Zhao, Y. Cheng, Y. Gan, R. Jia, L. Zhu, X. Sun, Anti-tubulin-alpha-1C autoantibody in systemic lupus erythematosus: a novel indicator of disease activity and vasculitis manifestations. Clinical rheumatology 37, 1229-1237 (2018).

186. T. Matthes, A. Wolff, P. Soubiran, F. Gros, G. Dighiero, Antitubulin antibodies. II. Natural autoantibodies and induced antibodies recognize different epitopes on the tubulin molecule. Journal of immunology (Baltimore, Md. : 1950) 141, 3135-3141 (1988).

187. A. Kimura, N. Yoshikura, A. Koumura, Y. Hayashi, Y. Kobayashi, I. Kobayashi, T. Yano, T. Inuzuka, Identification of target antigens of naturally occurring autoantibodies in cerebrospinal fluid. Journal of proteomics $128,450-457$ (2015).

188. L. Prasannan, D. E. Misek, R. Hinderer, J. Michon, J. D. Geiger, S. M. Hanash, Identification of betatubulin isoforms as tumor antigens in neuroblastoma. Clin Cancer Res 6, 3949-3956 (2000).

189. Y. Muro, Y. Ogawa, Y. Kato, M. Hagiwara, Autoantibody to thioredoxin reductase in an ovarian cancer patient. Biochemical and biophysical research communications 242, 267-271 (1998).

190. Z. E. Betteridge, H. Gunawardena, H. Chinoy, J. North, W. E. Ollier, R. G. Cooper, N. J. McHugh, U. K. A. O. M. I. Collaboration, Clinical and human leucocyte antigen class II haplotype associations of autoantibodies to small ubiquitin-like modifier enzyme, a dermatomyositis-specific autoantigen target, in UK Caucasian adult-onset myositis. Annals of the rheumatic diseases 68, 1621-1625 (2009). 
191. X. Li, J. Sun, R. Mu, Y. Gan, G. Wang, J. He, L. Yi, Q. Wang, X. Sun, Z. Li, The clinical significance of ubiquitin carboxyl hydrolase L1 and its autoantibody in neuropsychiatric systemic lupus erythematosus. Clinical and experimental rheumatology 37, 474-480 (2019).

192. Y. Zhou, J. Cui, H. Du, Autoantibody-targeted TAAs in pancreatic cancer: A comprehensive analysis. Pancreatology 19, 760-768 (2019).

193. K. Miyachi, H. Hosaka, N. Nakamura, H. Miyakawa, T. Mimori, M. Shibata, S. Matsushima, H. Chinoh, T. Horigome, R. W. Hankins, M. Zhang, M. J. Fritzler, Anti-p97/VCP antibodies: an autoantibody marker for a subset of primary biliary cirrhosis patients with milder disease? Scand J Immunol 63, 376-382 (2006).

194. F. J. Li, R. Surolia, H. Li, Z. Wang, T. Kulkarni, G. Liu, J. A. de Andrade, D. J. Kass, V. J. Thannickal, S. R. Duncan, V. B. Antony, Autoimmunity to Vimentin Is Associated with Outcomes of Patients with Idiopathic Pulmonary Fibrosis. Journal of immunology (Baltimore, Md. : 1950) 199, 1596-1605 (2017).

195. E. L. Paley, N. Alexandrova, L. Smelansky, Tryptophanyl-tRNA synthetase as a human autoantigen. Immunology letters 48, 201-207 (1995).

196. T. Mimori, Y. Ohosone, N. Hama, A. Suwa, M. Akizuki, M. Homma, A. J. Griffith, J. A. Hardin, Isolation and characterization of cDNA encoding the $80-\mathrm{kDa}$ subunit protein of the human autoantigen Ku (p70/p80) recognized by autoantibodies from patients with scleroderma-polymyositis overlap syndrome. Proceedings of the National Academy of Sciences of the United States of America 87, 1777-1781 (1990).

197. S. Hoa, M. Hudson, Y. Troyanov, S. Proudman, J. Walker, W. Stevens, M. Nikpour, S. Assassi, M. D. Mayes, M. Wang, M. Baron, M. J. Fritzler, G. Canadian Scleroderma Research, G. Australian Scleroderma Interest, S. Genetics versus Environment in Scleroderma Outcome, Single-specificity anti-Ku antibodies in an international cohort of 2140 systemic sclerosis subjects: clinical associations. Medicine (Baltimore) 95, e4713 (2016).

198. D. Braunschweig, P. Krakowiak, P. Duncanson, R. Boyce, R. L. Hansen, P. Ashwood, I. Hertz-Picciotto, I. N. Pessah, J. Van de Water, Autism-specific maternal autoantibodies recognize critical proteins in developing brain. Transl Psychiatry 3, e277 (2013).

199. A. Kistner, M. B. Bigler, K. Glatz, S. B. Egli, F. S. Baldin, F. A. Marquardsen, M. Mehling, K. M. Rentsch, D. Staub, M. Aschwanden, M. Recher, T. Daikeler, C. T. Berger, Characteristics of autoantibodies targeting 14-3-3 proteins and their association with clinical features in newly diagnosed giant cell arteritis. Rheumatology (Oxford, England) 56, 829-834 (2017).

200. M. H. van Beers-Tas, A. Marotta, M. Boers, W. P. Maksymowych, D. van Schaardenburg, A prospective cohort study of 14-3-3eta in ACPA and/or RF-positive patients with arthralgia. Arthritis research \& therapy 18, 76 (2016).

201. J. Qiu, G. Choi, L. Li, H. Wang, S. J. Pitteri, S. R. Pereira-Faca, A. L. Krasnoselsky, T. W. Randolph, G. S. Omenn, C. Edelstein, M. J. Barnett, M. D. Thornquist, G. E. Goodman, D. E. Brenner, Z. Feng, S. M. Hanash, Occurrence of autoantibodies to annexin I, 14-3-3 theta and LAMR1 in prediagnostic lung cancer sera. J Clin Oncol 26, 5060-5066 (2008).

202. R. Chakravarti, K. Gupta, M. Swain, B. Willard, J. Scholtz, L. G. Svensson, E. E. Roselli, G. Pettersson, D. R. Johnston, E. G. Soltesz, M. Yamashita, D. Stuehr, T. M. Daly, G. S. Hoffman, 14-3-3 in Thoracic Aortic Aneurysms: Identification of a Novel Autoantigen in Large Vessel Vasculitis. Arthritis Rheumatol 67, 1913-1921 (2015). 


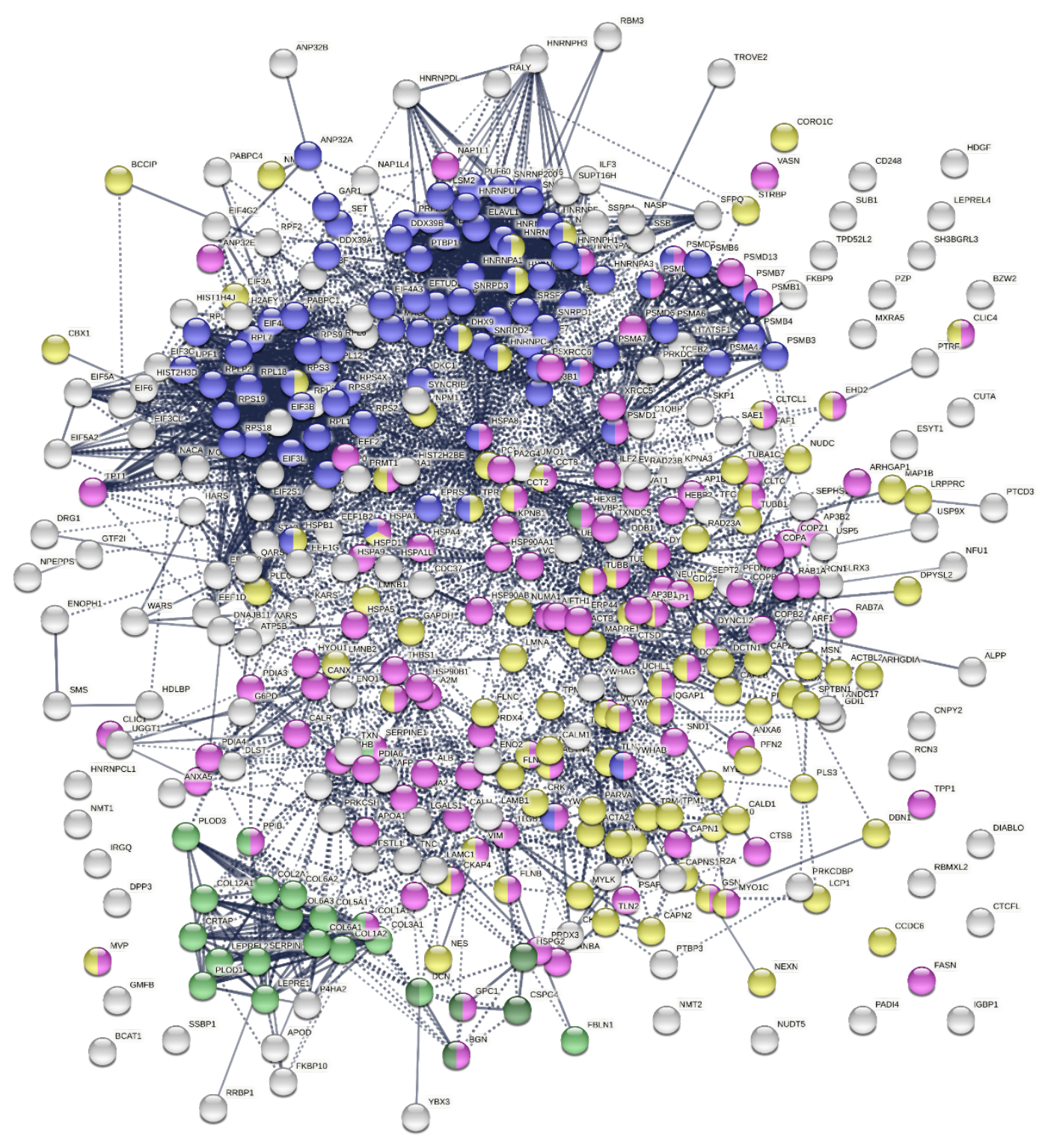

Fig. 1. The 408-protein autoantigenome identified by DS-affinity from HFL1 cells forms a highly interacting network. Connecting lines represent interactions with high confidence (minimum interaction score of 0.7) as per STRING analysis. Colored proteins are involved in metabolism of RNA (blue), vesicles (pink), cytoskeleton (gold), collagen and elastic fibers (light green), and chondroitin sulfate/dermatan sulfate metabolism (dark green). 


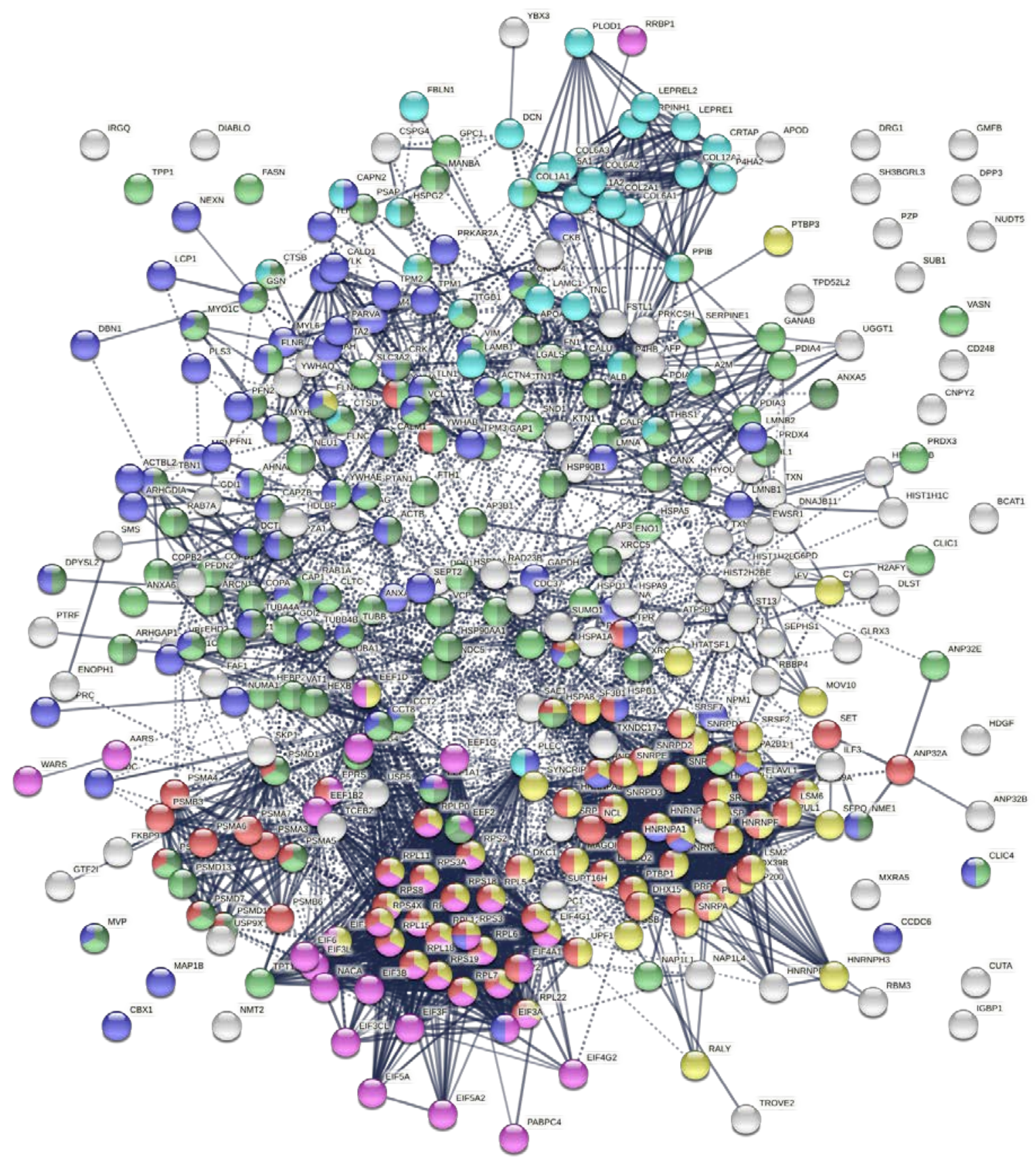

Fig. 2. Network of 352 autoantigenome proteins that are altered in SARS-CoV-2 infected cells or patients. Connecting lines represent interactions with high confidence. Colored proteins are involved in metabolism of RNA (77 proteins, red), mRNA metabolic process (69 proteins, gold), translation (43 proteins, pink), vesicles (99 proteins, light green) and vesicle-mediated transport (84 proteins, dark green), cytoskeleton (84 proteins, blue), and extracellular matrix organization (32 proteins, aqua). 


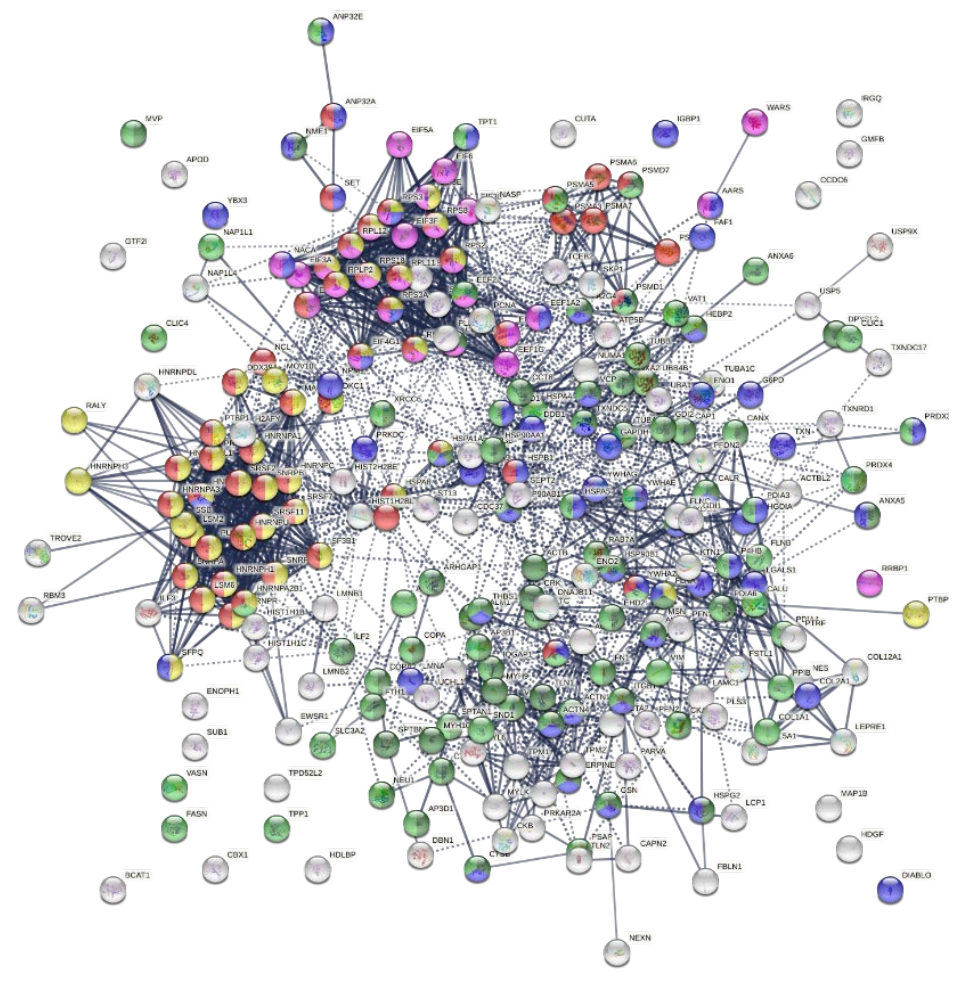

Fig. 3A. Interaction network of 260 up-regulated proteins in SARS-CoV-2 infected cells or patients. Connecting lines represent interactions with high confidence (minimum interaction score of 0.7 ). Colored proteins are involved in metabolism of RNA (54 proteins, red), translation (28 proteins, pink), vesicles (82 proteins, light green) and vesicle-mediated transport (67 proteins, dark green), regulation of cell death (61 proteins, blue), and mRNA metabolic process (46 proteins, gold).

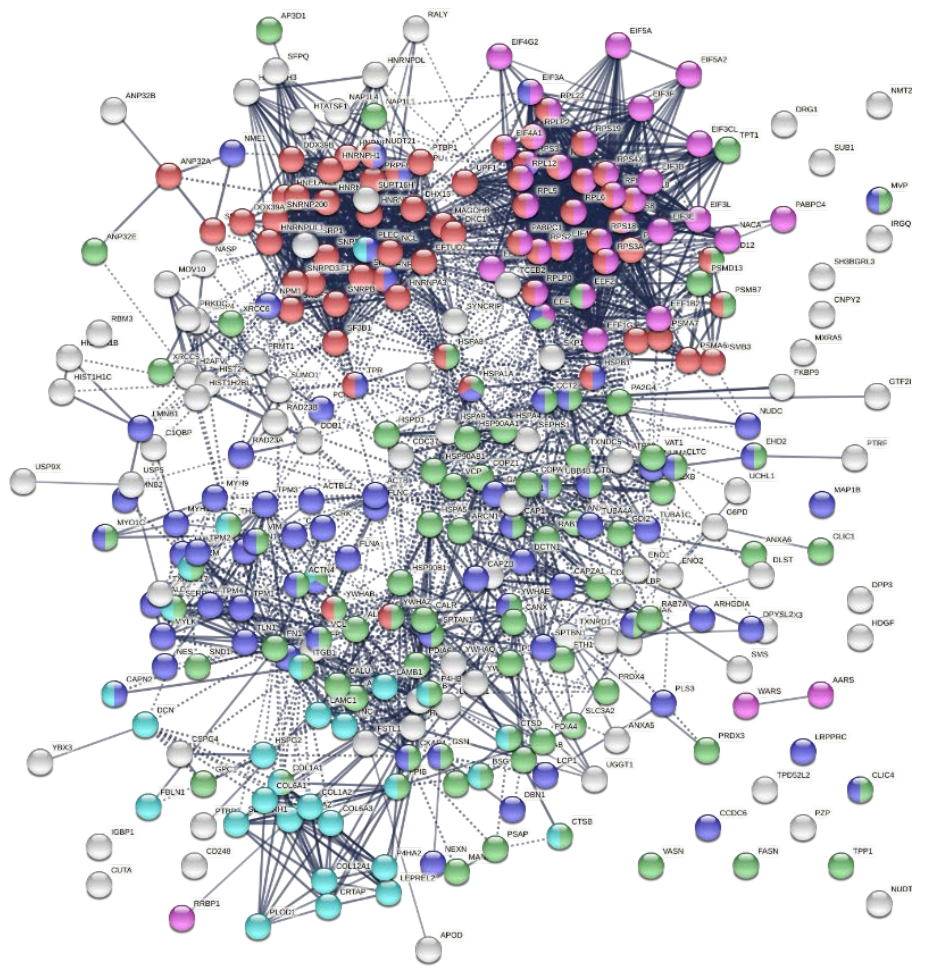

Fig. 3B. Interaction network of 303 down-regulated proteins in SARS-Cov-2 infected cells and patients. Connecting lines represent interactions with high confidence. Marked proteins are involved in RNA metabolism (64 proteins), translation (39 proteins, pink), vesicles (88 proteins, green), cytoskeleton (73 proteins, blue), and extracellular matrix organization (29 proteins, aqua). 


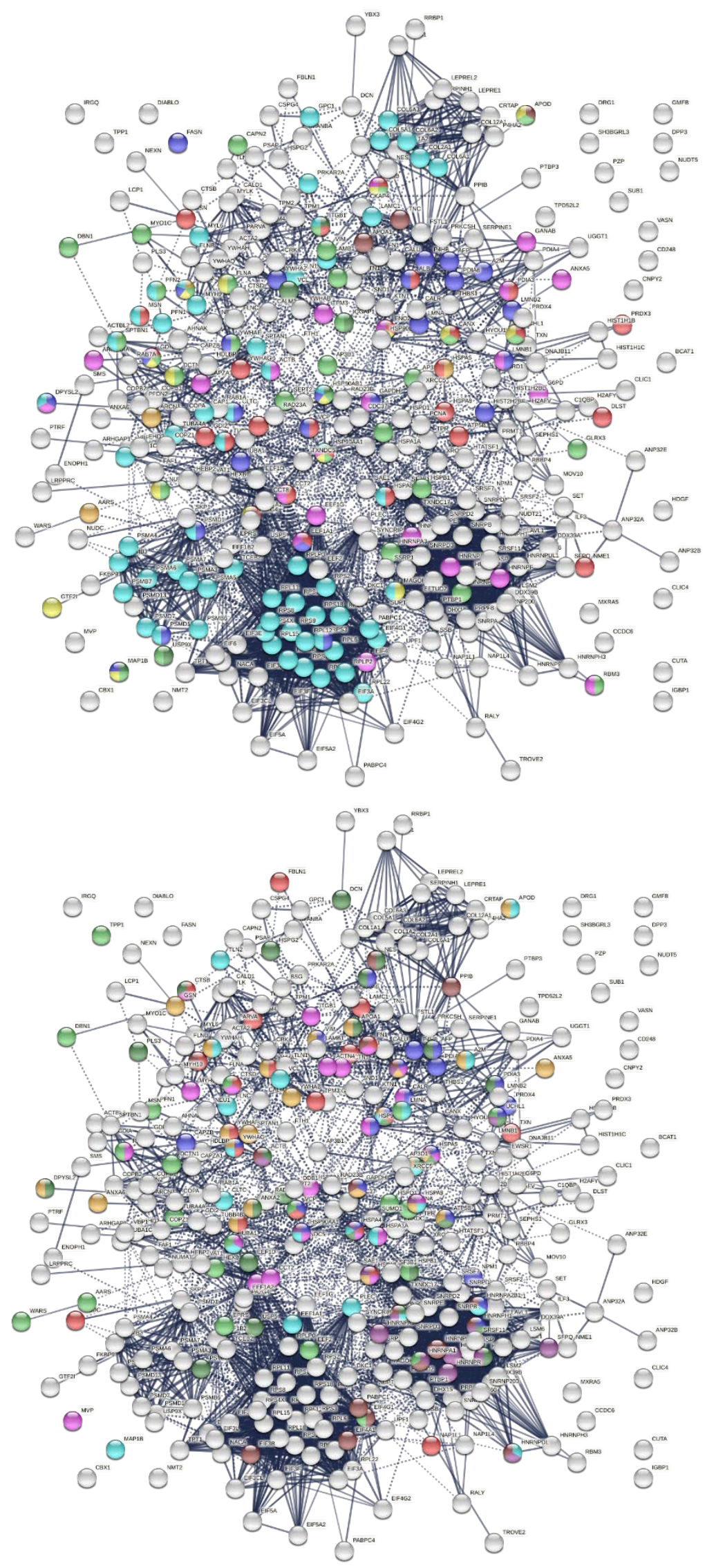

Fig. 4A. Nervous system-related proteins among COVID-altered proteins. Colored proteins are involved in axon guidance (62 proteins, aqua), axon growth cone (25 proteins, blue), myelin sheath (26 proteins, red), neuron projection (32 proteins, green) and neuron projection extension (7 proteins, dark green), neuronal cell body (16 proteins, gold), peripheral nervous system axon regeneration (3 proteins, brown), cerebellar Purkinje cell layer development (4 proteins, amber), and olfactory bulb (23 proteins, pink).

Fig. 4B. Neurological diseaserelated proteins among proteins altered in COVID. Colored are proteins found in neuronal infection with Japanese encephalitis virus (23 proteins, blue), neuroblastoma (21 proteins, red), glioblastoma (22 proteins, pink), neurodegeneration in Down syndrome (26 proteins, dark green), Alzheimer disease (22 proteins, aqua), schizophrenia (24 proteins, amber), cerebral ischemia induced neurodegenerative diseases (17 proteins, dark purple), Parkinson disease (17 proteins, brown), and neurodegeneration (21 proteins, green). 

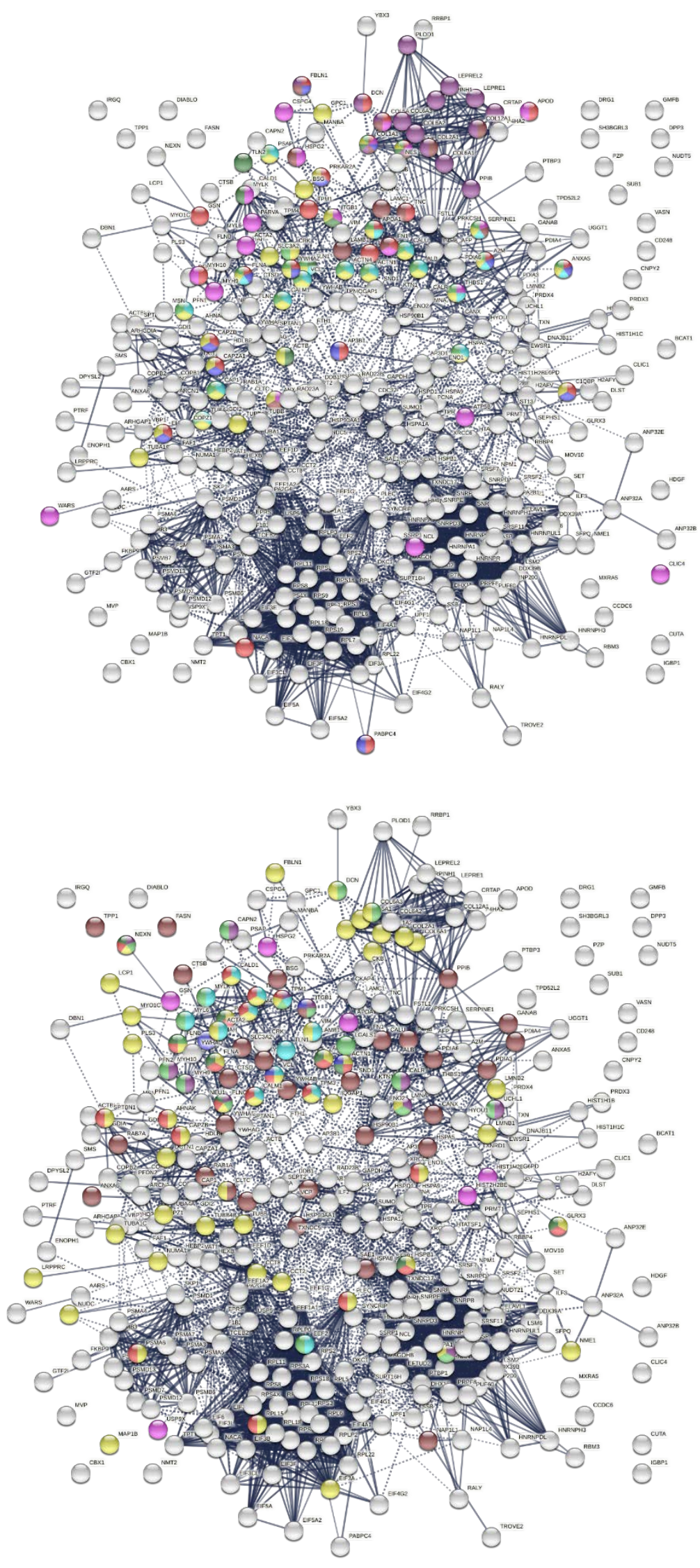

Fig. 5A. Relation of COVIDaltered proteins to wound healing and hemostasis. Response to wounding (25 proteins, red), blood vessel development (20 proteins, pink), blood coagulation (14 proteins, blue), collagencontaining extracellular matrix (13 proteins, brown), collagen biosynthesis and modifying enzymes (16 proteins, dark purple), platelet activation (3 proteins, dark green) and platelet activation signaling and aggregation (22 proteins, green), platelet degranulation proteins, aqua), and hemostasis (35 proteins, gold).

Fig. 5B. Other significantly enriched groups among altered proteins. Supramolecular fiber (56 proteins, amber), melanosome (30 proteins, brown), striated muscle cell differentiation (11 proteins, purple), myofibril (23 proteins, red), muscle structure development (18 proteins, green), muscle contraction (13 proteins, aqua), $Z$ disk (9 proteins, dark green), intercalated disk (4 proteins, blue), and amyloid fiber formation (6 proteins, pink). 

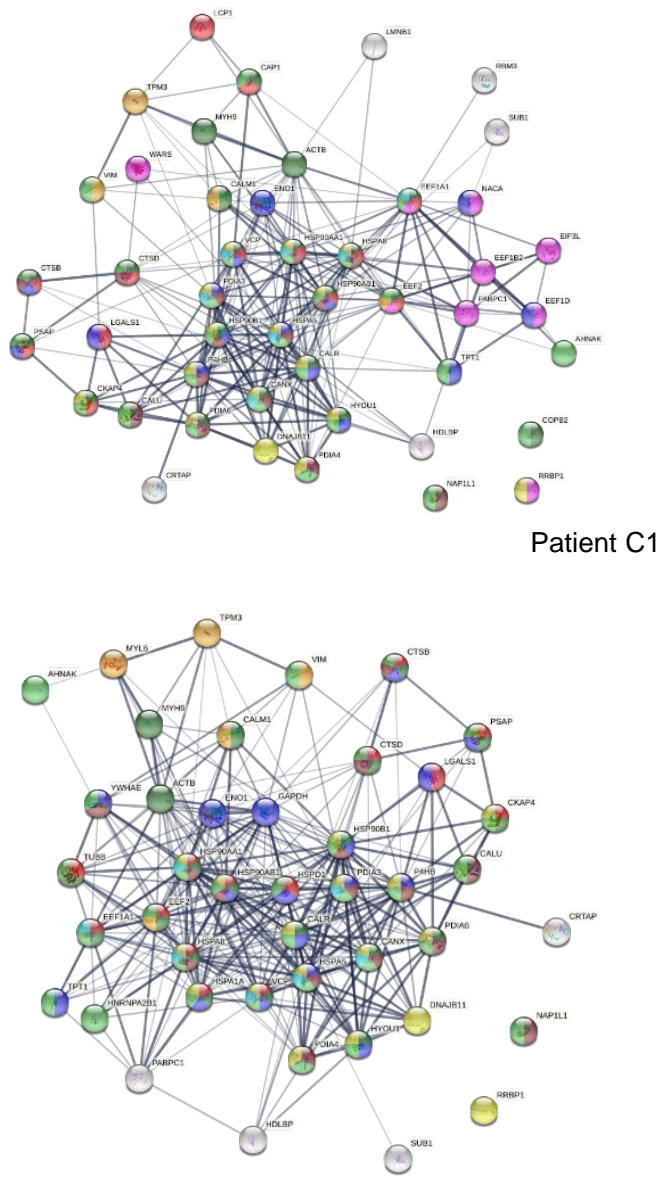

Patient C3

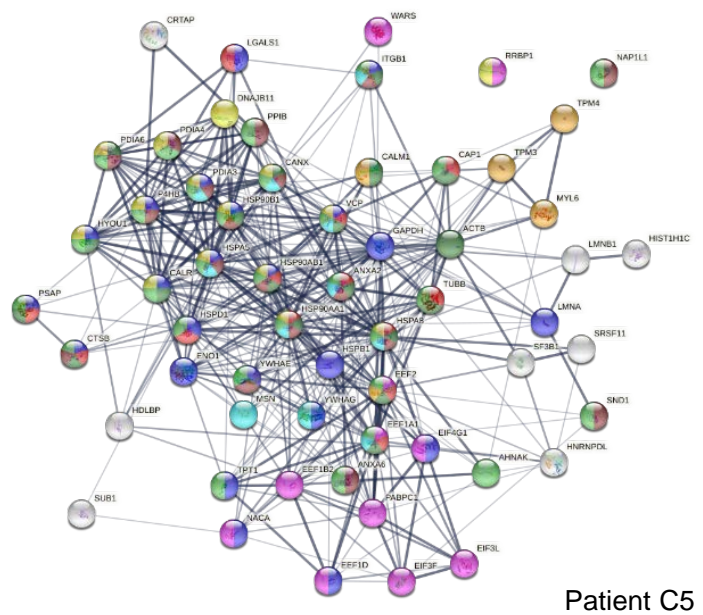

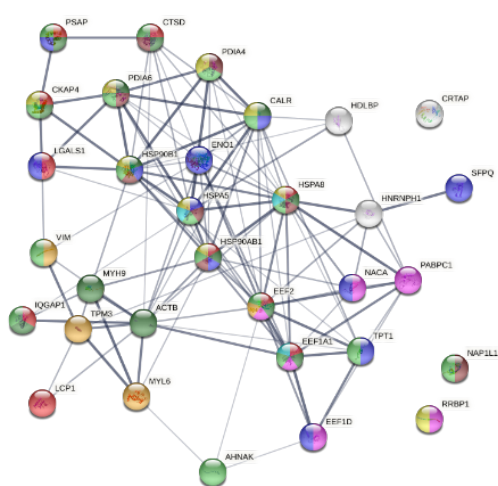

Patient C2
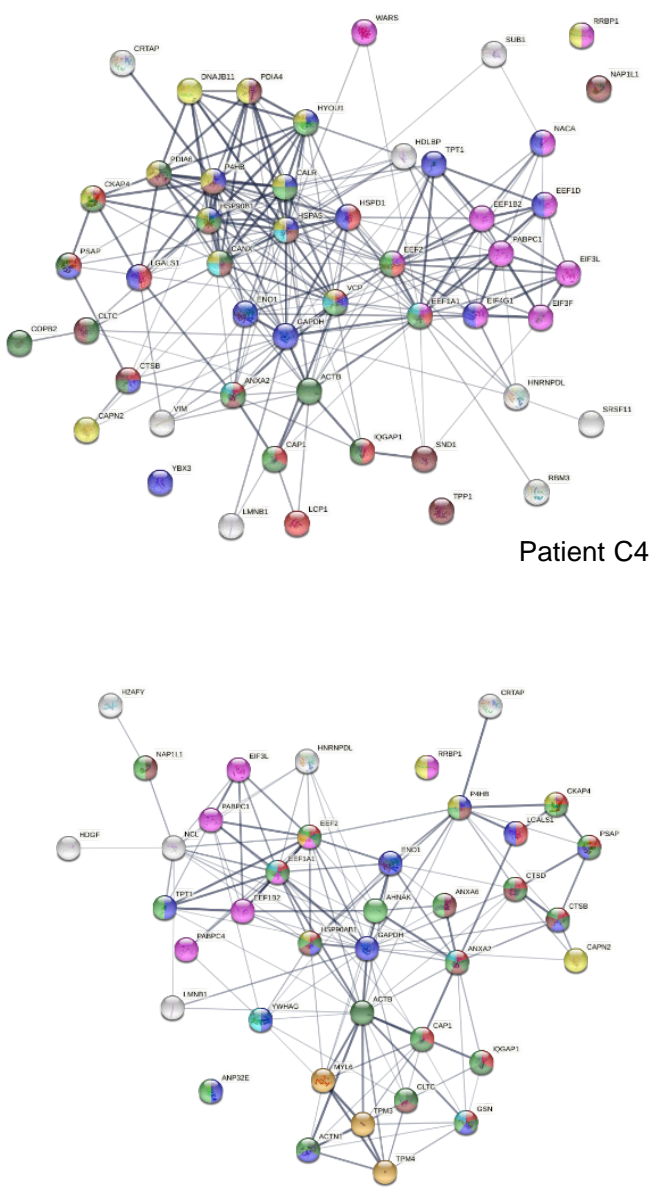

Patient C6

Fig. 6. Interaction network of altered proteins in 6 COVID-19 patients. Colored proteins are associated with leukocyte activation involved in immune response (red), vesicles (light green) and vesicle-mediated transport (dark green), protein processing in the ER (yellow), regulation of cell death (blue), translation (pink), melanosome (brown), myelin sheath (aqua), and muscle contraction (amber). 


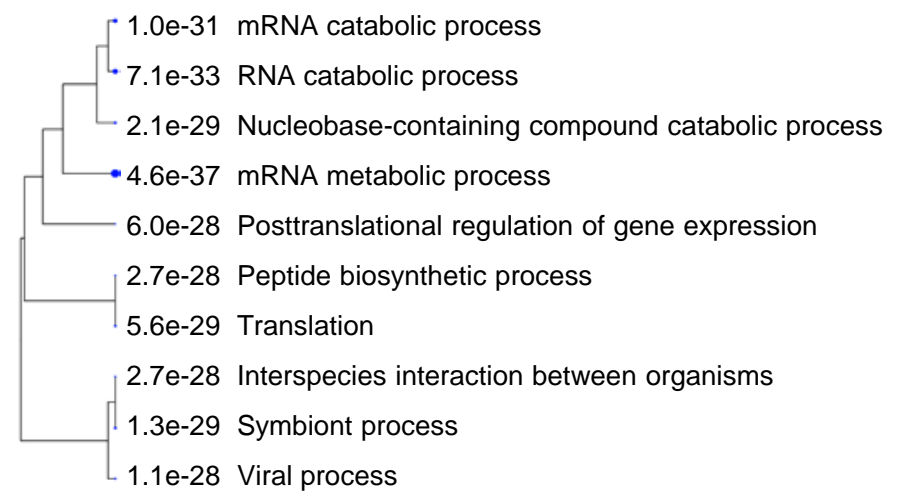

Fig. 7A. Hierarchical clustering of top 10 pathways involving COVIDaltered proteins. Analysis based on hypergeometric distribution followed by FDR correction.

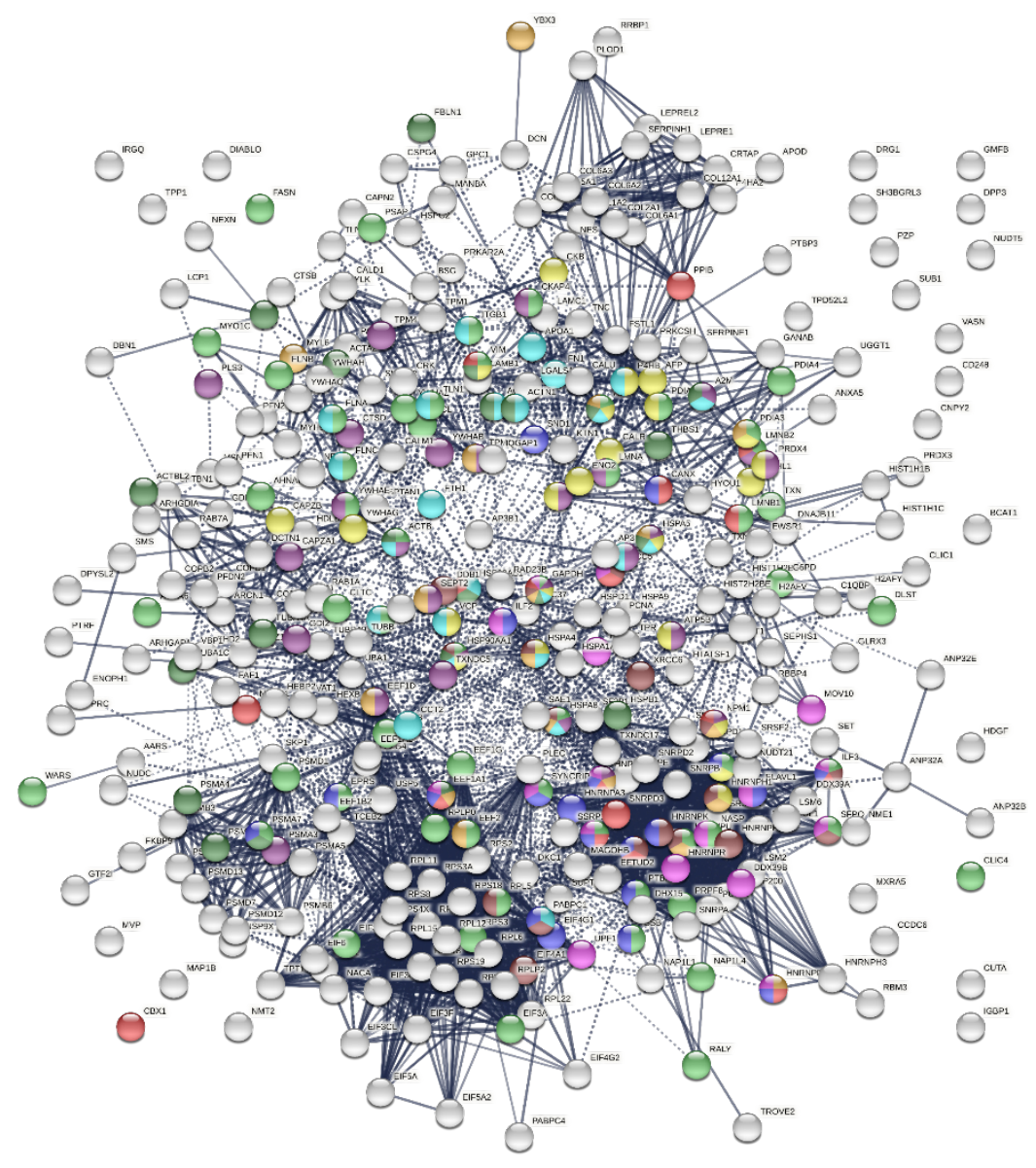

Fig. 7B. COVID-altered host proteins with DS-affinity found in various viral infections. Porcine reproductive and respiratory syndrome (56 proteins, green), H5N1 avian influenza virus (27 proteins, dark purple), Japanese encephalitis virus (23 proteins, gold), Rift Valley fever virus (24 proteins, aqua), Hepatitis B virus (22 proteins, dark green), HIV (identified in different studies, 18 amber, 18 brown, 18 red and 17 pink), and shared among positive-sense RNA viruses (20 proteins, blue). 